The Free Internet Journal for Organic Chemistry
Review

Arkivoc 2018, part vi, 85-138

\title{
Amidines: their synthesis, reactivity, and applications in heterocycle synthesis
}

\author{
Ashraf A. Aly, ${ }^{* a}$ Stefan Bräse, ${ }^{b, c}$ and Mohsen A.-M. Gomaa ${ }^{a}$ \\ ${ }^{a}$ Chemistry Department, Faculty of Science, Minia University, El-Minia-61519, Egypt \\ ${ }^{b}$ Institute of Organic Chemistry, Karlsruhe Institute of Technology,76131 Karlsruhe, Germany \\ c Institute of Toxicology and Genetics, Hermann-von-Helmholtz-Platz 1, D-76344 Eggenstein-Leopoldshafen, \\ Germany \\ E-mail: ashrafaly63@yahoo.com; ashraf.shehata@mu.edu.eg
}

Received 04-27-2018

Accepted 07-10-2018

Published on line 09-02-2018

\section{Abstract}

The reactivity of amidines makes them valuable as building blocks for the synthesis of heterocyclic motifs of biological relevance, for functional materials, for organo-catalysts and as ligand in metal-complexes. As a large number of publications have recently reported on the reactivity of amidines, we compiled some features of these interesting molecules. Consequently, this article aims to review the preparation of functionalized amidines and to highlight their use as starting materials in the synthesis of various organic molecule classes, especially heterocyclic structures. In this review, we cover also related name reactions such as the Pinner reaction.
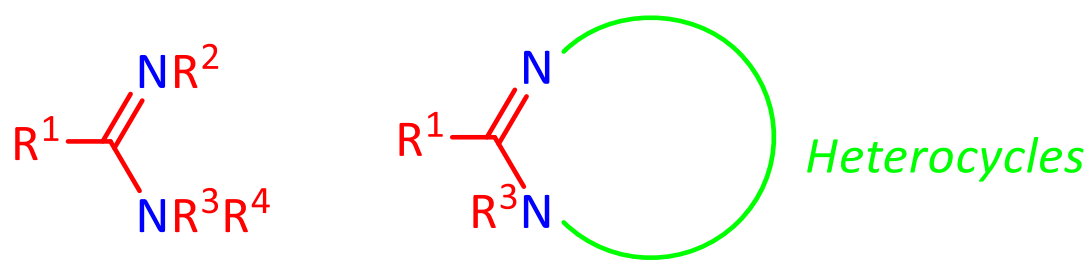

Keywords: Amidines, preparation, three-membered rings, four-membered rings, five-membered rings, heterocycles; secretase inhibitor; Pinner reaction; Pinner salt, amidinium salts; Baylis-Hillman 


\section{Table of Contents}

1. Introduction

2. Amidines as Naturally Occurring Compounds

3. General Methods for the Preparation of Amidines

3.1 Amidines from nitriles

3.2 Amidines from amides

3.3 Amidines from carbodiimides

3.4 Amidines from aldoximes

3.5 Amidines from 1,2,4-oxadiazol-5-ones

3.6 Amidines from 1,2,3-benzotriazole

3.7 Amidines from aminopyrazoles

3.8 Amidines by arylation of amidine salts

3.9 Amidines by reaction of isothiocyanates with sec-amines

4. Synthesis of Various Classes of Amidine

4.1 Synthesis of amidoximes

4.2 Synthesis of polysubstituted amidines

4.3 Synthesis of acetamidines

4.4 Synthesis of $N$-sulfonyl amidines

4.5 Synthesis of $\mathrm{N}$-imidoylsulfinformamidines

4.6 Synthesis of phosphoryl amidines

4.7 Synthesis of $N, N$-substituted amidines

4.8 Synthesis of $\alpha, \beta$-unsaturated amidines

4.9 Utility of nanocatalysis in the synthesis of amidines

4.10 One-pot three component reactions

4.11 Synthesis of $\mathrm{N}$-alkoxy amidine salts

4.12 Synthesis of bis-amidines

4.13 Synthesis of cyclic amidines

4.13.1 Synthesis of monocyclic amidines

4.13.2 Synthesis of bicyclic-amidines

5. Chemical Reaction of Amidines

5.1 Addition of amidines to electrophiles

5.2 Synthesis of heterocyclic derivatives

5.2.1 Synthesis of three-membered rings

5.2.2 Synthesis of four-membered rings

5.2.3 Synthesis of five-membered rings

5.2.3.1 Pyrroles

5.2.3.2 Thiazoles

5.2.3.3 Imidazoles

5.2.3.4 Oxadiazoles

5.2.3.5 Thiadiazoles

5.2.3.6 Triazoles

5.2.4 Synthesis of six-membered rings

5.2.4.1 Pyridines 


\subsubsection{Pyrimidines}

5.2.4.3 Thiadiazines

5.2.4.4 Triazines

5.2.4.5 Tetrazines

5.2.4.6 Thiatriazines

\subsubsection{Synthesis of seven-membered rings}

5.2.5.1 Thiazepines

Abbreviations

Acknowledgements

References

\section{Introduction}

Compounds having amidine group 1a have a structure analogue of carboxylic acids and esters 2 (Figure 1). ${ }^{1}$ Either $N^{1}$ or $N^{3}$ in amidine 1a can share with their lone of electrons and subsequently the resonated structure $\mathbf{1 b}$ is formed (Figure 1). ${ }^{2,3}$

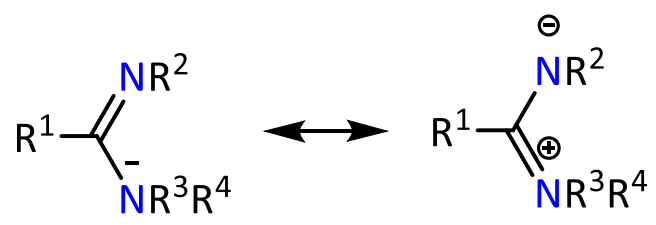

$1 a$<smiles>[R]OC([R])=O</smiles>

2

Figure 1. Resonance forms of amidines.

Amidines (imidamides) are described as strong organic bases ( $p K_{a}$ ranges from $5-12$ ). 4,5 The amidinium ion $\mathbf{3}$ is stabilized by resonance. Deprotonation in strong alkaline solution enhances the formation of an anion $\mathbf{4}$ (Figure 2). ${ }^{6-8}$

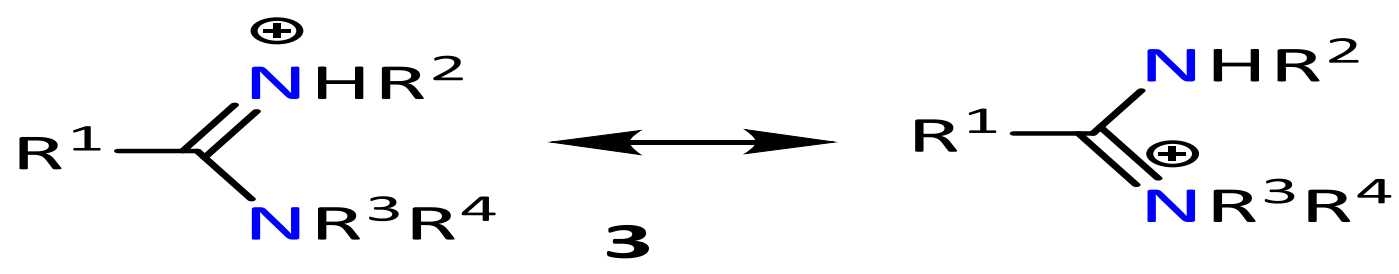

Figure 2. Protonation and deprotonation of amidines.

In addition, amidines served as well-suited hydrogen bond-donor acceptor pair with carboxylic acid and therefore are used in catalysis and materials sciences.

Well over one million amidines and around 30000 acyclic amidines are known (source: SciFinder), thus only a selection is covered in this review. Very prominent examples are DBU (over 8000 references) and DBN 
(nearly 2000 references), The cyclic amidines such as DBN and DBU (Figure 3) are also very potent catalysts, for instance in Baylis-Hillman reactions. We do not include metal complexes with amidine ligands.<smiles>C1CN=C2CCCN2C1</smiles>

2,3,4,6,7,8-Hexahydropyrrolo[1,2-a]pyrimidine (1,5-Diazabicyclo[4.3.0]non-5-ene, DBN)

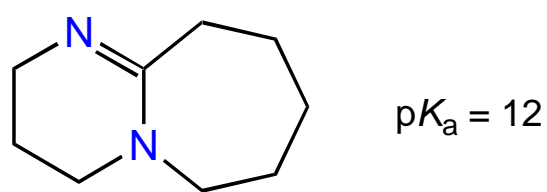

2,3,4,6,7,8,9,10-Octahydropyrimido[1,2-a]azepine (1,8-Diazabicyclo[5.4.0]undec-7-ene, DBU)

Figure 3. Structures of DBN and DBU.

\section{Amidines as Naturally Occurring Compounds}

As there is a long list of biologically active amidines, it is beyond the scope of this review to list and discuss them all. However, we would like to give prototypic examples. Functionalized amidines have been isolated as fermentation products of Actinomycetes. For example, bottromycin, a macrocyclic peptide with antibiotic activity, isolated from Streptomyces bottropensis, ${ }^{9-11}$ Other amidines have been isolated from fungi, marine invertebrates and plants. Also complex amidines can be found in nature; fromiamycalin is an example for this, which was isolated from Fromia monilis (Figure 4). ${ }^{12-14}$

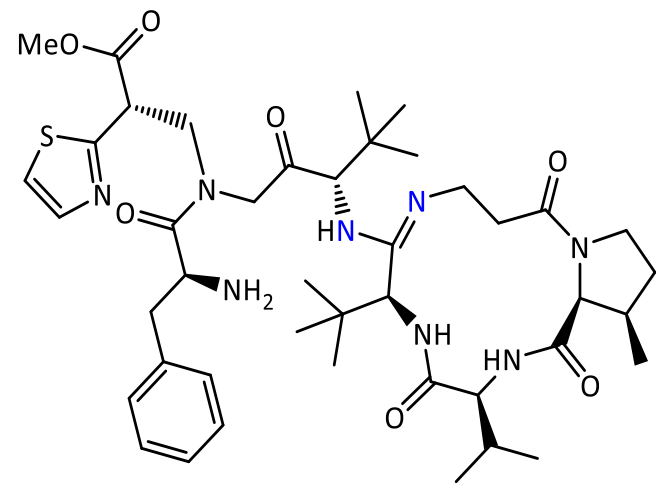

Bottromycin A2

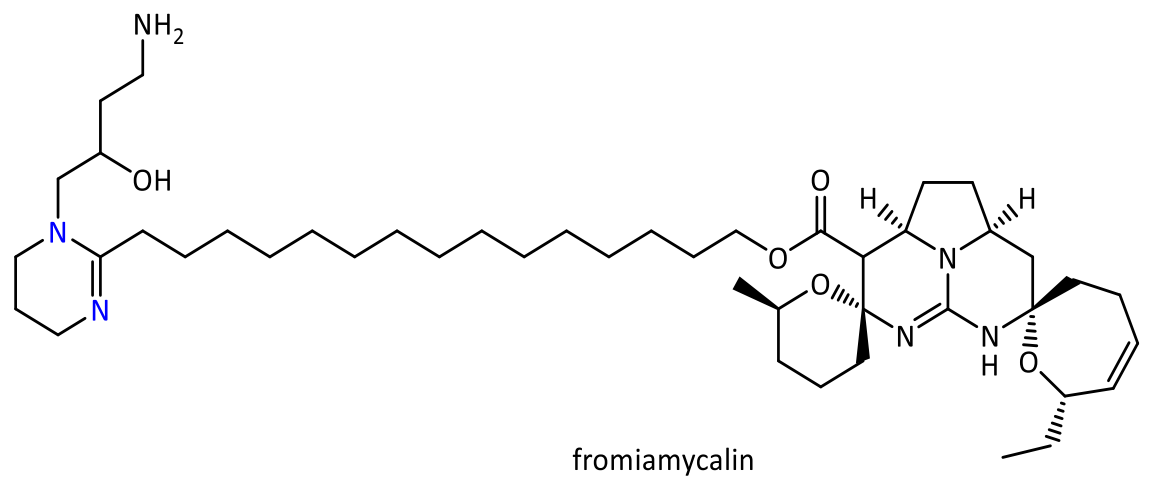

Figure 4. Some naturally-occurring amidine structures.

\section{General Methods for the Preparation of Amidines}

Substituted amidines are useful intermediates in the synthesis of many heterocyclic and alicyclic compounds. Consequently, numerous methods have been shown the preparation of this important class. ${ }^{15}$

\subsection{Amidines from nitriles}

The addition of primary amines to nitriles catalyzed by ytterbium amides $\mathbf{5}$ furnished amidines $\mathbf{7}$. The reaction is suggested to proceed via formation of intermediate 6 (Scheme 1). ${ }^{16}$ 


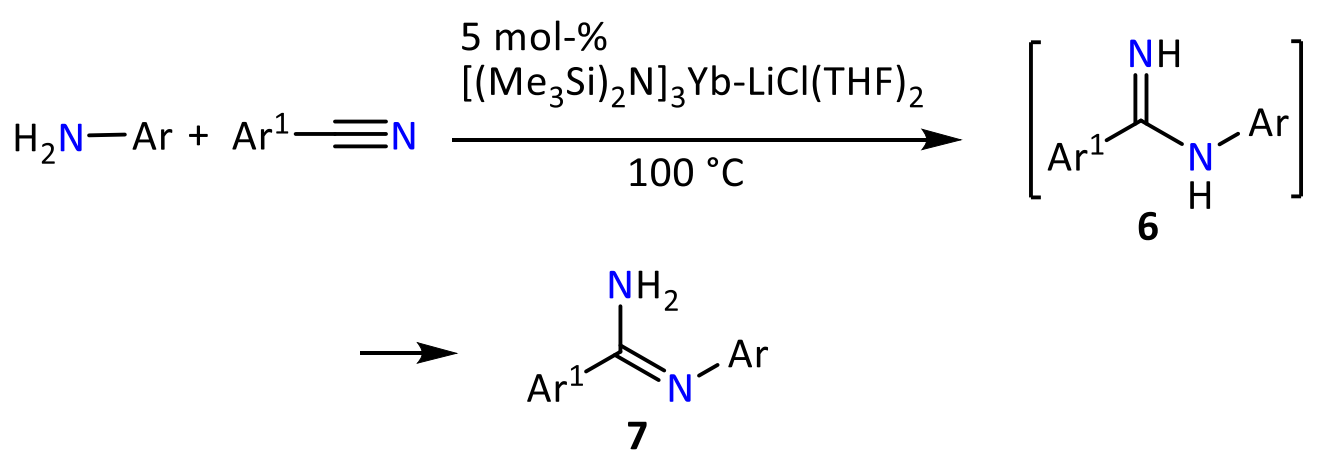

Scheme 1. Synthesis of amidines $\mathbf{7}$ from amines and nitriles in presence of ytterbium amides $\mathbf{5}$

2-Ethoxy-5-((4-methylpiperazin-1-yl)sulfonyl)benzonitrile (8) was converted into the amidine 9 in $58 \%$ yield by reaction with methyl-chloroaluminum amide 10 (Scheme 2 ). ${ }^{17}$<smiles>CCOc1ccc(S(=O)(=O)N2CCN(C)CC2)cc1C#N</smiles>

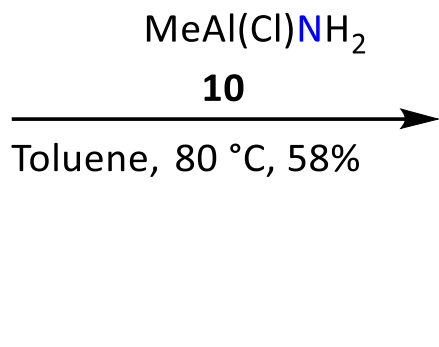<smiles>CCOc1ccc(S(=O)(=O)N2CCN(C)CC2)cc1C(=N)N</smiles>

Scheme 2. Conversion of nitrile group in $\mathbf{8}$ into amidine in $\mathbf{9}$ in presence of catalyst $\mathbf{1 0 .}$

Previously, it was reported that primary amines were deprotonated with $n$-BuLi before addition of aryl nitriles. ${ }^{18,19}$ A series of nitrile compounds were added under the same conditions, to the anion of amines. The amidines 7A were obtained after acidic work up in moderate yields (Scheme 3). ${ }^{20}$

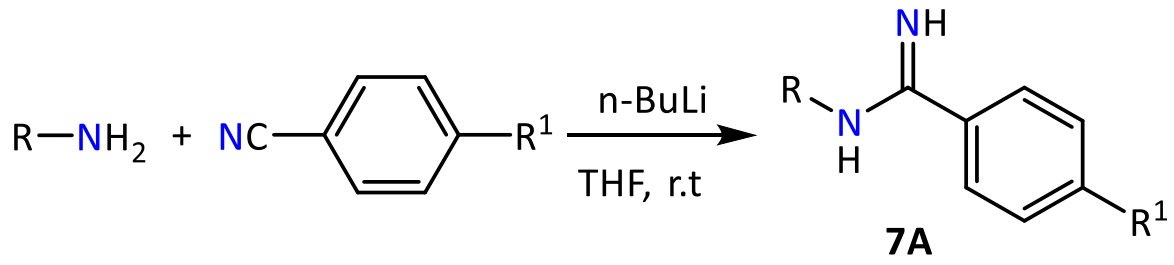

Scheme 3. Synthesis of amidines 7 from amines and nitriles in presence of BuLi.

The oxidation of heteroaryl aminoacetonitriles 10 using $\mathrm{NiO}_{2}-\mathrm{H}_{2} \mathrm{O}$ or $\mathrm{MnO}_{2}$ in the presence of substituted amines afforded amidine derivatives 11a-f (Scheme 4). ${ }^{21}$ Side products of this reaction are diethyl arylamides 12a-f (Scheme 4). ${ }^{21}$ It was proposed that the reaction occurred via formation of intermediate $\mathbf{A}$, which was trapped by a primary amine to form a $N, N, N^{\prime}$-trisubstituted amidine. ${ }^{21}$ Hydrolysis of 11 a-f by water present in the reaction medium gave also side products 12a-f (Scheme 4). 


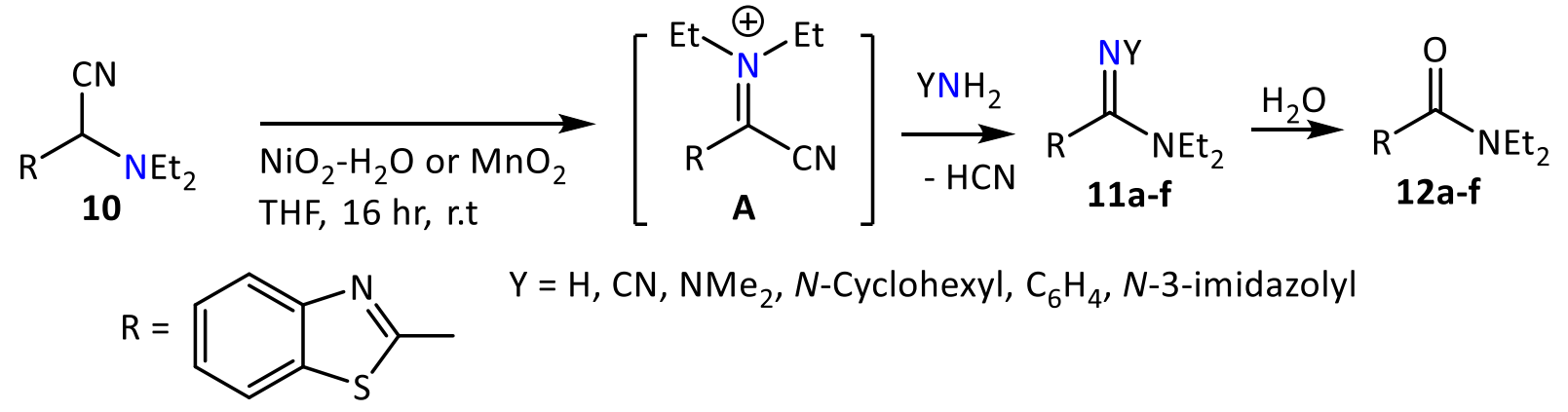

Scheme 4. Formation of benzothiazolylamidines 11.

In the same article it was reported that when the anion of $\mathrm{N}, \mathrm{N}$-diethylaminoacetonitrile, prepared by deprotonation with NaHDMS in tetrahydrofuran (THF), was treated with 2-chlorobenzothiazole (12) to give intermediate $\mathbf{B}$. Oxidation of $\mathbf{B}$ by $\mathrm{NiO}_{2}-\mathrm{H}_{2} \mathrm{O}$ in the presence of $n$-propylamine, afforded the benzothiazole amidine $\mathbf{1 3}$ in an isolated yield of $35 \%$ (Scheme 5). ${ }^{21}$

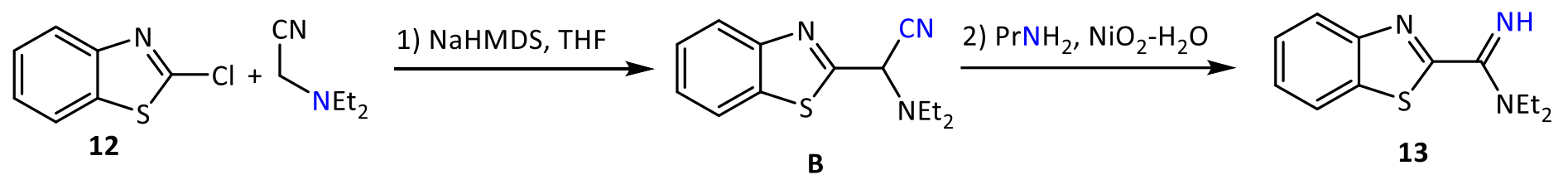

Scheme 5. Preparation of amidine 13.

Aryl nitriles were converted into amidines $7 \mathrm{~B}$ by one of the reactions A or B as shown in (Scheme 6). ${ }^{22}$

Reaction A

1) $\mathrm{HCl} / \mathrm{EtOH}, 2) \mathrm{NH}_{4} \mathrm{Cl} / \mathrm{MeOH}$

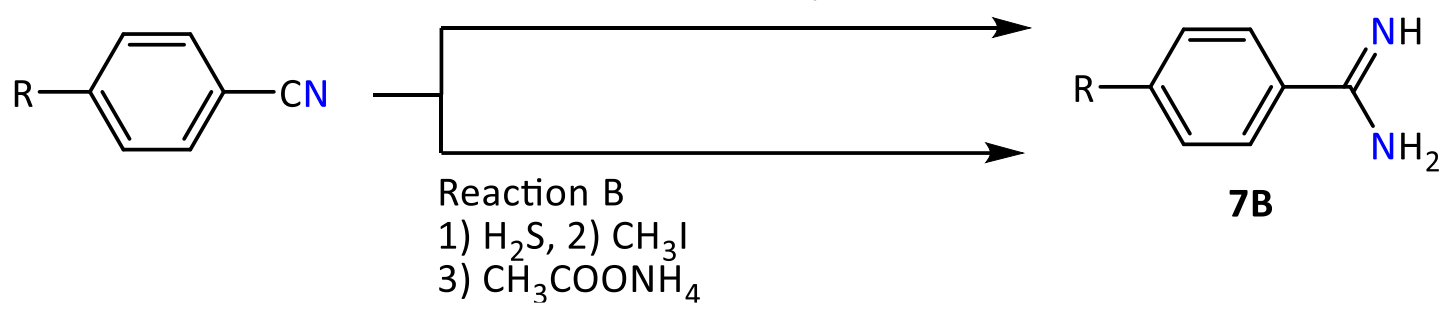

Scheme 6. Synthesis of amidines $\mathbf{7}$ from substituted nitriles.

Imidates $\mathbf{1 4}$ were synthesized by alcoholysis of aromatic and benzylic nitriles according to the well-known Pinner reaction by bubbling anhydrous $\mathrm{HCl}$ gas into an equimolar mixture of aromatic or benzylic nitrile derivatives and methanol according to the sequence of steps in Scheme 7. ${ }^{23,24}$ 


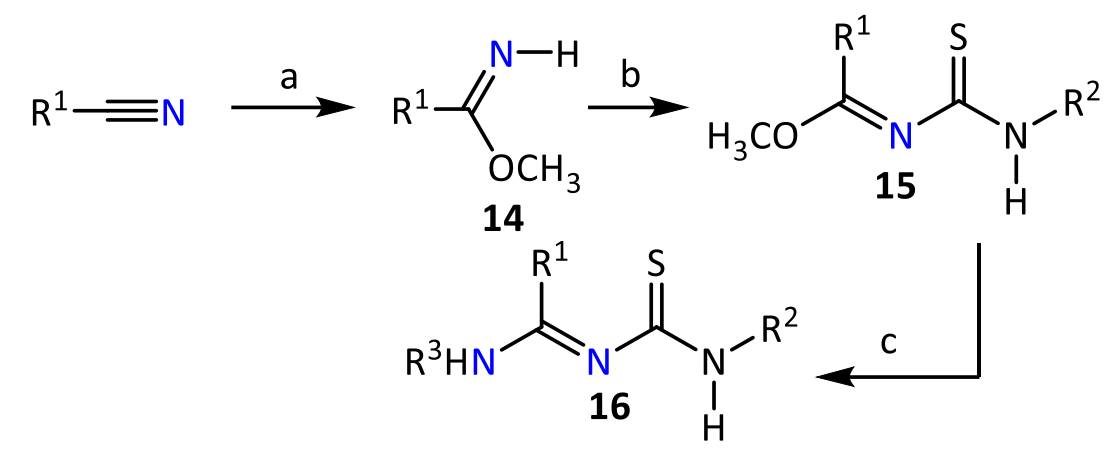

Scheme 7. Synthesis of thioamidoamidines 16. a: $\mathrm{MeOH}, \mathrm{HCl}(\mathrm{g}) / \mathrm{Et}_{2} \mathrm{O} ; \mathrm{NaOH}(10 \%) / \mathrm{Et}_{2} \mathrm{O} ; \mathrm{b}: \mathrm{R}^{2} \mathrm{NCS} / \mathrm{THF} ; \mathrm{c}$ : $\mathrm{R}^{3} \mathrm{NH}_{2} / \mathrm{MeOH}$.
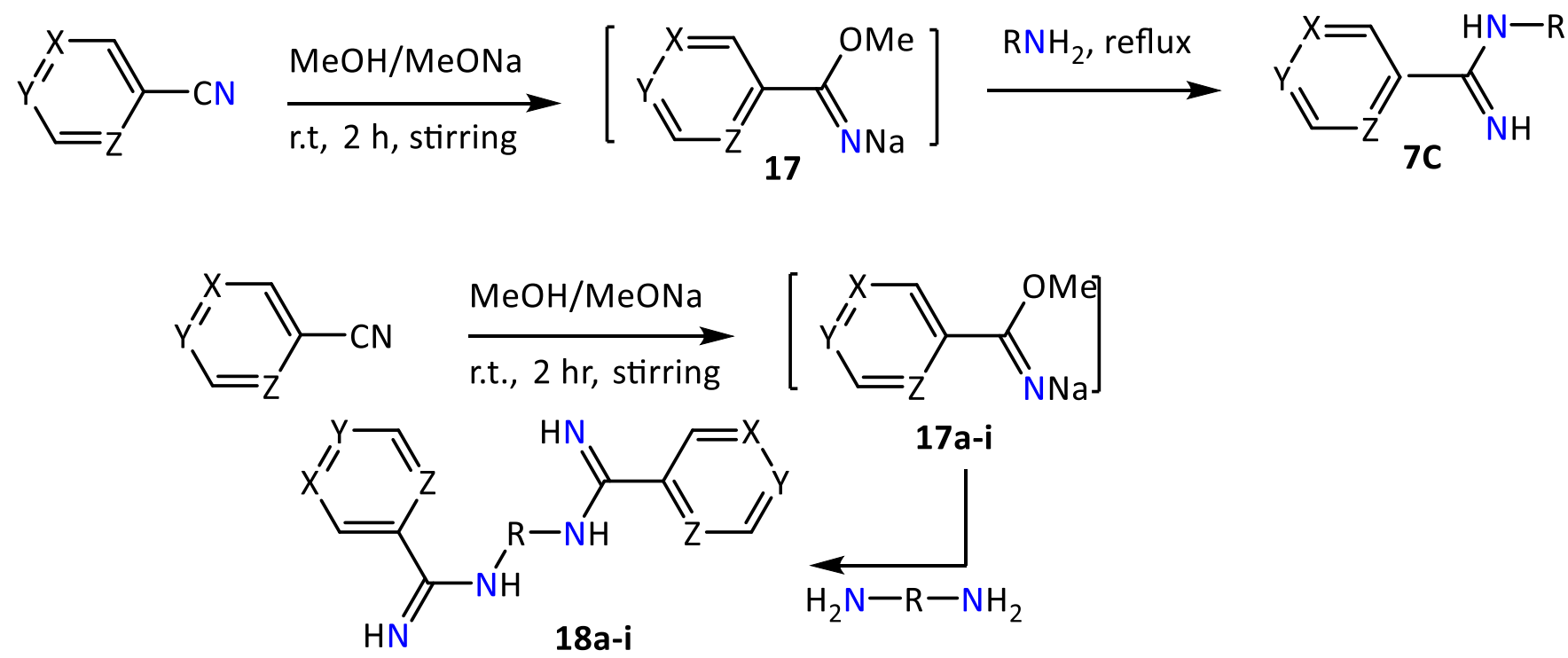

\begin{tabular}{l|llll}
$\mathbf{1 8}$ & $\mathrm{X}$ & $\mathrm{Y}$ & $\mathrm{Z}$ & $\mathrm{R}$ \\
\hline $\mathbf{a}$ & $\mathrm{CH}$ & $\mathrm{CH}$ & $\mathrm{N}$ & $\begin{array}{l}\left(\mathrm{CH}_{2}\right)_{4} \\
\left(\mathrm{CH}_{2}\right)_{4} \\
\text { b }\end{array}$ \\
$\mathrm{CH}$ & $\mathrm{N}$ & $\mathrm{CH}$ & $\left(\mathrm{CH}_{2}\right)_{4}$ \\
e & $\mathrm{N}$ & $\mathrm{CH}$ & $\mathrm{N}$ & \\
c & $\mathrm{CH}$ & $\mathrm{CH}$ & $\mathrm{N}$ & $\left(\mathrm{H}_{3} \mathrm{C}\right)_{2}$ \\
d & $\mathrm{CH}$ & $\mathrm{N}$ & $\mathrm{CH}$ & \\
f & $\mathrm{N}$ & $\mathrm{CH}$ & $\mathrm{N}$ & $\mathrm{C}_{6} \mathrm{H}_{4}-\mathrm{C}_{6} \mathrm{H}_{4}$ \\
g & $\mathrm{CH}$ & $\mathrm{CH}$ & $\mathrm{N}$ & $\mathrm{C}_{6} \mathrm{H}_{4}-\mathrm{C}_{6} \mathrm{H}_{4}$ \\
h & $\mathrm{CH}$ & $\mathrm{N}$ & $\mathrm{CH}$ & $\mathrm{C}_{6} \mathrm{H}_{4}-\mathrm{C}_{6} \mathrm{H}_{4}$ \\
i & $\mathrm{N}$ & $\mathrm{CH}$ & $\mathrm{N}$ & $\mathrm{C}_{6} \mathrm{H}_{4}-\mathrm{C}_{6} \mathrm{H}_{4}$
\end{tabular}

Scheme 8. Synthesis of amidines from reaction of nitriles with amines in presence of methoxide. 
Condensation of various isothiocyanates to the imidates 14 in anhydrous tetrahydrofuran gave $\mathrm{N}$ thioamidoimidates $15 .^{23}$ Reaction of $\mathbf{1 5}$ with primary amines in anhydrous methanol, allowing $N$ thioamidoamidines $\mathbf{1 6}$ formation after the substitution of methoxy group by amino (Scheme 7). ${ }^{23}$ Therefore and when nitriles reacted with sodium methoxide the reaction was proposed to give intermediate 17 , which underwent reaction with aliphatic amines under the conditions of Scheme 8, to give the corresponding amidine derivatives $7 \mathrm{C}$ (Scheme 8 ). ${ }^{24}$ Therefore, the synthesis of amidine derivatives was carried out by condensation of 17a-i with primary diamine in 2:1 molar ratio, in the presence of sodium methoxide. This reaction gave amidine derivatives $18 \mathrm{a}-\mathbf{i}$ in good yields (Scheme 8). ${ }^{25}$ When evaluated for anti-inflammatory activity and in vitro anticancer activity some amidines of type of 18a-i exhibited good anti-inflammatory potency whereas others showed good breast (T47D), lung (NCI H-522), colon (HCT-15), ovary (PA-1) and liver (HepG2) anticancer activity. ${ }^{25}$

An isoxazoline nitrile was coupled with a substituted $\beta$-alanine derivative to afford the amido-nitrile intermediate 19, which was converted into the substituated amidines by treatment with the appropriate alkyl or benzyl amine in ethanol after hydrolysis $\mathbf{2 0}$ (Scheme 9). ${ }^{26}$
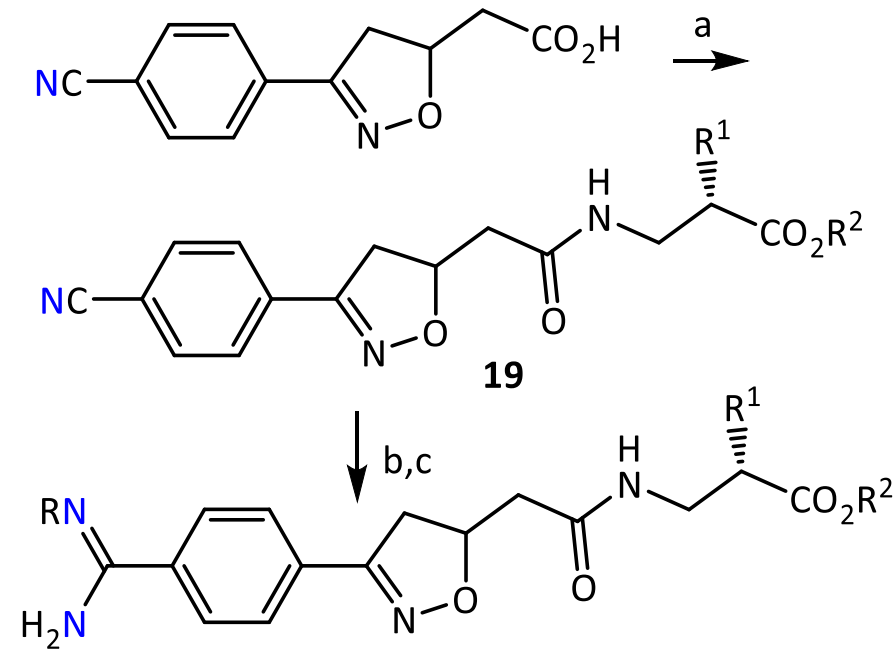

20

Scheme 9. Synthesis of amidines 20. Reagents and conditions: (a) TBTU (2-(1H-benzotriazole-1-yl)-1,1,3,3tetramethyluronium tetrafluoroborate)/ $\mathrm{Et}_{3} \mathrm{~N} / \mathrm{DMF} / \alpha$-substituted $\beta$-alanine; (b) $\mathrm{EtOH} / \mathrm{HCl}, \mathrm{RNH}_{2} / \mathrm{EtOH}$; (c) $\mathrm{LiOH} / \mathrm{H}_{2} \mathrm{O} / \mathrm{MeOH}$.

Oxidation of bromide $\mathbf{2 1}$ with 2-nitropropane/sodium methoxide gave naphthaldehyde 22, which was exposed to Pinner conditions to afford the formylnaphthylamidine hydrochloride 23 (Scheme 10). ${ }^{27}$

Starting from available ethyl (Z)- $N$-(2-amino-1,2-dicyanovinyl)formimidate (24), ${ }^{28-30} N$-aryl (or benzyl-)- $N^{\prime}(-$ 2-amino-1,2-dicyanovinyl)formamidines $\mathbf{2 5}$ were prepared in good yields by reaction with anilines (Scheme 11). ${ }^{31}$ 


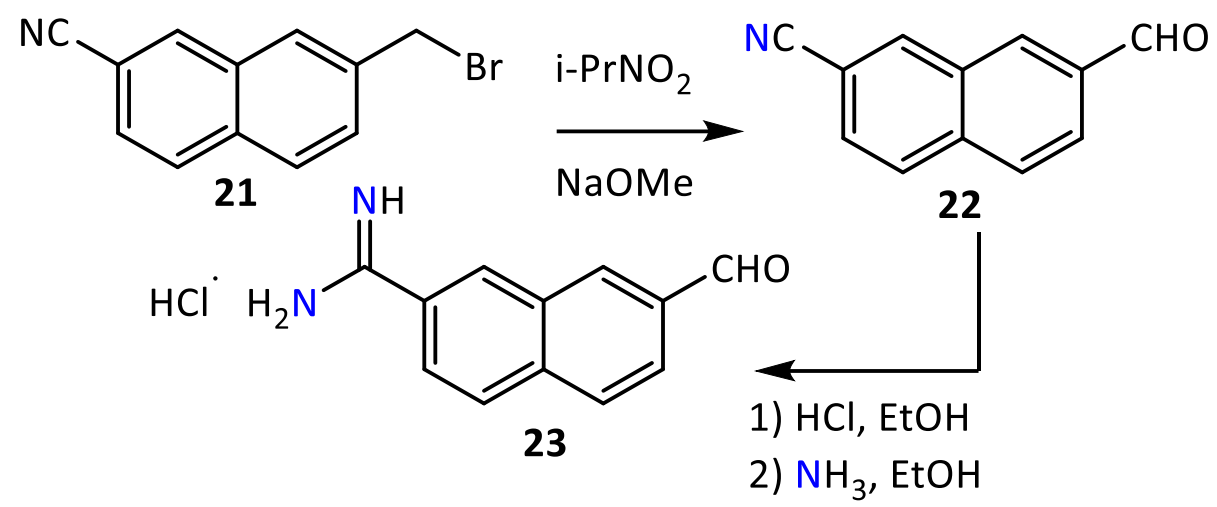

Scheme 10. Synthesis of amidine salts 23.
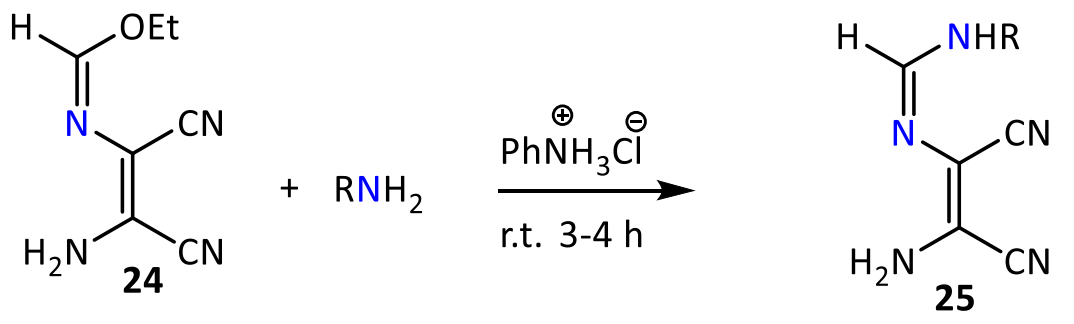

\begin{tabular}{l|ll}
$\mathbf{2 5}$ & & Yield (\%) \\
\hline a & $\mathrm{R}=2-\mathrm{ClC}_{6} \mathrm{H}_{4} \mathrm{CH}_{2}$ & 92 \\
b & $\mathrm{R}=3,4-\left(\mathrm{CH}_{3} \mathrm{O}\right)_{2} \mathrm{C}_{6} \mathrm{H}_{4} \mathrm{CH}_{2}$ & 94 \\
c & $\mathrm{R}=3,4-\left(\mathrm{CH}_{3} \mathrm{O}\right)_{2} \mathrm{C}_{6} \mathrm{H}_{3}$ & 96 \\
d & $\mathrm{R}=4-\mathrm{CH}_{3} \mathrm{OC}_{6} \mathrm{H}_{4}$ & 93
\end{tabular}

Scheme 11. Synthesis of amidines 25.

The anthranilic amidines $\mathbf{2 8}$ were synthesized via reductive amination of 26 with 4-pyridine carboxaldehyde in the presence of $\mathrm{NaCNBH}_{3}$, giving the corresponding benzonitriles 27. Thereafter, reaction of $\mathbf{2 7}$ with various amines promoted by trimethylaluminum produced amidines $\mathbf{2 8}$ in moderate yields (Scheme 12). ${ }^{32}$ Amidines 28 showed interesting biological activities as kinase inhibitors of Flt-1 and KDR (Kinase-insert domain-containing receptor), respectively.<smiles>[R]NC(=N)c1cc([R1])c([R])cc1NCc1ccncc1</smiles>

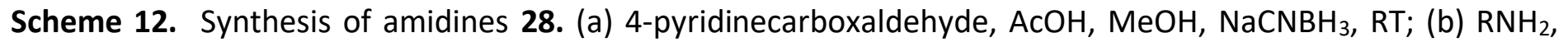
$\mathrm{AlMe}_{3}$, toluene, $28-80 \%$. 
8-(Aminopyrimidinyl)naphthalenes $\mathbf{3 1}$ were prepared via nitration of naphthalene $\mathbf{2 9}$ followed by reduction and then $\mathrm{Pd}$-catalyzed amine coupling to 2-bromopyrimidine by the sequences shown in Scheme 13. The resulting ester $\mathbf{3 0}$ was then hydrolyzed and coupled to aniline to give amidonitriles, which were converted via thioamides to the amidines 31 in the presence of HATU (1-[bis(dimethylamino)methylene]-1 $\mathrm{H}-1,2,3-$ triazolo[4,5-b]pyridinium 3-oxide hexafluorophosphate) along with Hünig's base ( $N, N$-diisopropylethylamine, DIPEA) using DMF as solvent. That was followed by thioamide formation using $\mathrm{H}_{2} \mathrm{~S}$ and then amination (Scheme 13). The isolated amidines showed activity as inhibitors of the serine protease urokinase plasminogen activator (UPA). ${ }^{33}$<smiles>COC(=O)c1ccc2cc(C#N)ccc2c1</smiles>

Scheme 13. Synthesis of amidines 31. Reagents and Conditions: (a) $\mathrm{KNO}_{3}, \mathrm{H}_{2} \mathrm{SO}_{4}, \mathrm{O}^{\circ} \mathrm{C}$; (b) $\mathrm{H}_{2}, 10 \% \mathrm{Pd} / \mathrm{C}$, EtOAc, THF; (c) 2-bromopyrimidine, $\mathrm{Pd}_{2} \mathrm{dba}_{3}$, BINAP, NaO-t-Bu, toluene, $80{ }^{\circ} \mathrm{C}$; (d) $\mathrm{LiOH}, \mathrm{THF}, \mathrm{H}_{2} \mathrm{O}$; (e) aniline, HATU, DIPEA, DMF; (f) $\mathrm{H}_{2} \mathrm{~S}$, TEA, pyridine, then Mel, acetone, then $\mathrm{NH}_{4} \mathrm{OAc}, \mathrm{MeOH}$.

The reaction of 2-cyanopyridine with 3-(4'-methoxyphenyl)-4-phenyl-2-imino-4-thiazolines 32 gave the amidines 33 in good yield (Scheme 14). ${ }^{34}$

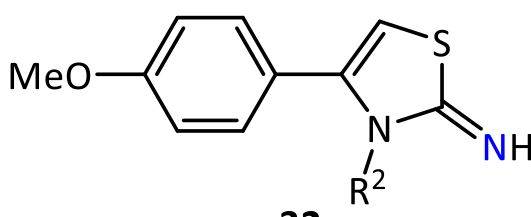

32

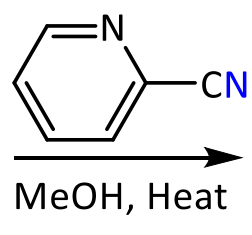

$\mathrm{MeOH}$, Heat<smiles>[R2]n1c(-c2ccc(OC)cc2)cs/c1=N/C(=N)c1ccccn1</smiles>

Scheme 14. Synthesis of amidines 33. 
Reaction of an aniline 34 with $N, N^{1}$ thiocarbonyldiimidazole (35) followed by displacement of the second imidazole with an acetamidine moiety produced as 2-aryl-[N-(N-4-cyanophenyl-N-methylthiocarbamoyl)]acetamidines 37 in good yields (Scheme 15). ${ }^{35}$<smiles>CNc1ccc(C#N)cc1</smiles><smiles>N=C(N)C[Al]</smiles><smiles>CN(C(=S)NC(=N)C[Al])c1ccc(C#N)cc1</smiles>

Scheme 15. Synthesis of amidines 37.

As a general method, nitrile groups (i.e. in arylnitriles) can be converted into hydroxyamidine derivatives 38 by their direct reaction with hydroxylamine (Scheme 16). ${ }^{36-39}$ The latter can serve as precursors for amidines.

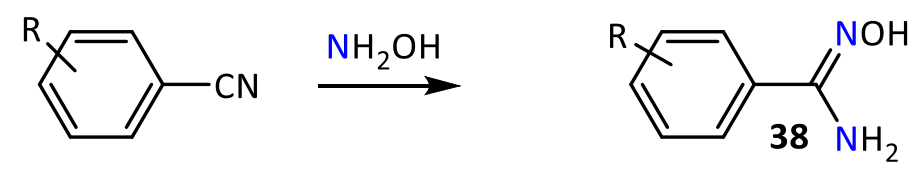

\begin{tabular}{r|cclll}
$\mathbf{3 8}$ & $\mathbf{a}$ & $\mathbf{b}$ & $\mathbf{c}$ & $\mathbf{d}$ & $\mathbf{e}$ \\
\hline $\mathrm{R}$ & $4-\mathrm{F}$ & $4-\mathrm{Me}$ & $3-\mathrm{Cl}$ & $4-\mathrm{CF}_{3}$ & $3-\mathrm{CF}_{3}$ \\
Yield (\%) & 90 & 92 & 85 & 91 & 96
\end{tabular}

Scheme 16. Synthesis of hydroxyamidines 38.

\subsection{Amidines from amides}

When 2,6-diisopropylaniline (40) was treated with one equivalent of aroyl chloride in an aqueous potassium hydroxide solution, the resulting amides $\mathbf{4 1}$ were formed (Scheme 18). ${ }^{40}$ Subsequently, arylamides 41 were converted into the corresponding imidoyl chlorides 42, which on treatment with 40 in the presence of triethylamine $\left(\mathrm{Et}_{3} \mathrm{~N}\right)$ gave $N, N^{\prime}$-bis (2',6'-diisopropylphenyl)aryl-diamide (43, Scheme 18). ${ }^{40}$

The synthesis of amidines was also achieved by the addition of amines to amides activated with trifluoromethanesulfonic anhydride $\left(\mathrm{Tf}_{2} \mathrm{O}\right)$ in the presence of pyridine. Various disubstituted and trisubstituted amidines 7D were prepared via the formation of salt 44 (Scheme 19). ${ }^{41,42}$ 


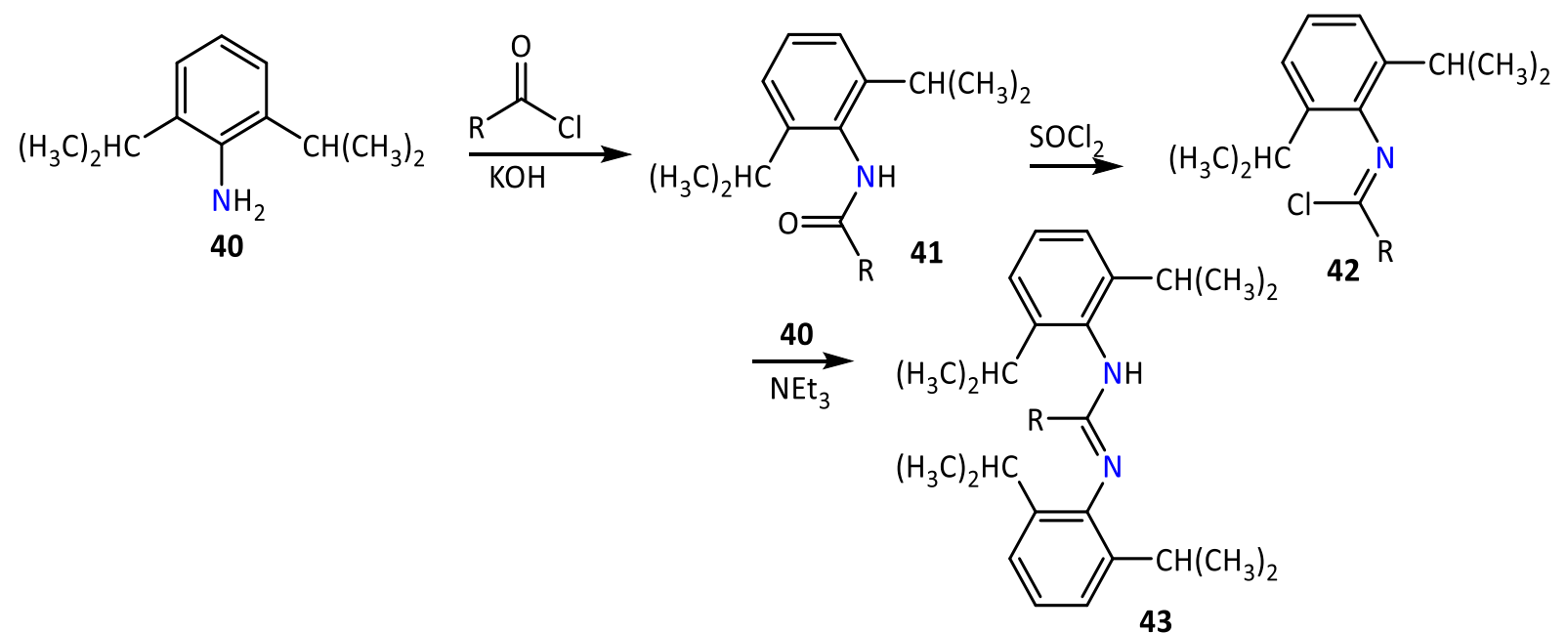

Scheme 18. Synthesis of amidines 43.<smiles>[R]C(=O)N([R])[R1]([H])([H])OCC</smiles>

44<smiles>[R]N=C([R])N([R])[R]</smiles>

7D

Scheme 19. Synthesis of amidines 7D from amide derivatives.

\subsection{Amidines from carbodiimides}

Bromoaryl derivatives 45 underwent lithio-debromination with $n$-BuLi, followed by reaction with a diaryl carbodiimide, to give the anion $\mathbf{4 6}$. Hydrolysis of $\mathbf{4 6}$ gave the corresponding amidines $7 \mathrm{E}$ (Scheme 20). ${ }^{43}$

ortho-Lithiation of 9,9-dimethyl-9H-xanthene (47) with BuLi in the presence of tetramethylethylenediamine (TMEDA) in hexane has been used to generate the aryl dianion. Reaction under the previous conditions with a dimine moiety (e.g. $i-\operatorname{PrN}=\mathrm{C}=\mathrm{N}-i-\operatorname{Pr}(\mathrm{DIC})(\mathbf{4 8})$ produced in good yield the ortho-bisamidine derivative 49 (Scheme 21). ${ }^{44}$ For the synthesis of other bisamidines, see Section 3.12.

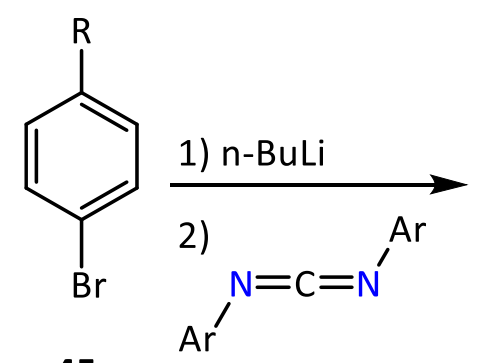

45<smiles></smiles>

46<smiles>[R]c1ccc(/C(=N/Br)N[Ga])cc1</smiles>

7E

Scheme 20. Synthesis of amidines 7. 
<smiles>CC1(C)c2ccccc2Oc2ccccc21</smiles>

TMEDA, BuLi<smiles>CCCN=C(NC(C)C)c1cccc2c1Oc1c(C(=NC(C)C)NC(C)C)cccc1C2(C)C</smiles>

Scheme 21. Synthesis of ortho-bisamidine 49.

\subsection{Amidines from aldoximes}

Chlorination of azomethines of hydroxylamines by $\mathrm{N}$-chlorosuccinimide in dichloromethane (DCM) afforded intermediates 50 (Scheme 22). 1,3-Dipolar cycloaddition of imines with nitrile oxides (resulting on treatment of $\mathbf{5 0}$ by trimethylamine) formed 4,5-dihydro-1,2,4-oxadiazoles $\mathbf{5 1}$. Reduction of the $\mathrm{N}-\mathrm{O}$ bond led to the formation of monosubstituted $\mathrm{N}$-aryl amidines $7 \mathrm{~F}$ in good yield (Scheme 22). ${ }^{45}$

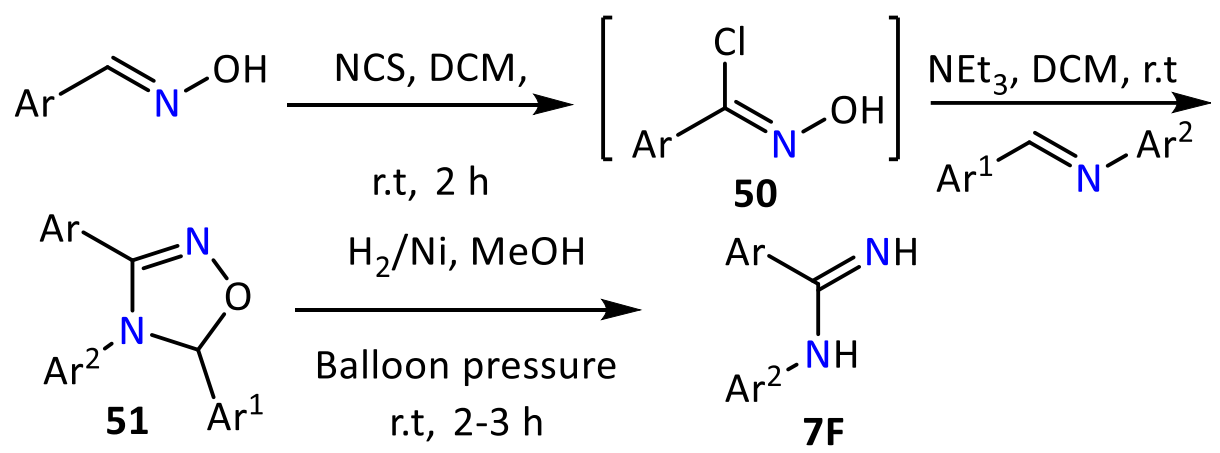

Scheme 22. Synthesis of amidines 7F from aldoximes.

The reduction of amidoximes using triethylsilane $\left(\mathrm{Et}_{3} \mathrm{SiH}\right)$ as a reducing agent with the aid of palladium chloride in the presence of acetic acid gave amidines 7G (Scheme 23). ${ }^{46}$<smiles>[R]/C(N)=N/O</smiles>

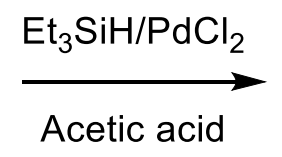<smiles>[R]C(=N)N</smiles>

Scheme 23. Synthesis of amidines 7G using $\mathrm{Et}_{3} \mathrm{SiH} / \mathrm{PdCl}_{2}$.

\subsection{Amidines from 1,2,4-oxadiazol-5-ones}

Amidines $\mathbf{7 H}$ were prepared by the stepwise reduction of 5-benzyloxy-1,2,4-oxadiazole derivatives $\mathbf{5 2}$ using two equivalents of $\mathrm{H}_{2}$ withPd/C (Scheme 24). ${ }^{47}$ Decarboxylation yields the final compounds. 


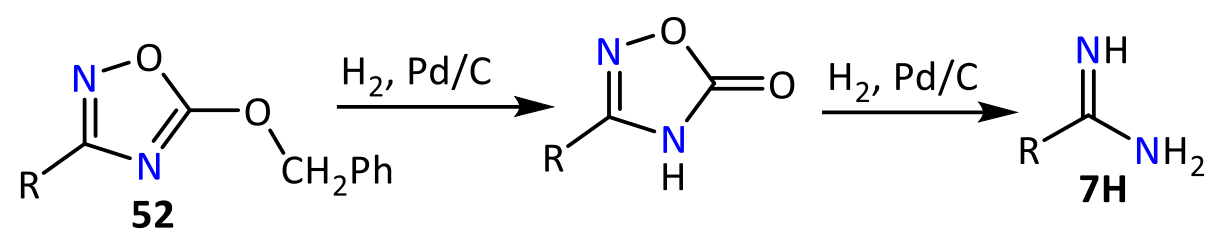

Scheme 24. Stepwise synthesis of amidines $7 \mathbf{H}$ from 1,2,4-oxadiazole-5-one using reduction over Pd/C.

\subsection{Amidines from 1,2,3-benzotriazole}

1,2,3-Benzotriazol-1-yl-( $N$-aryl)amidines 54 were synthesized by the reaction between 1,2,3-benzotriazole (53) and arylcyanamides (ArNHCN) under either thermal or microwave conditions (Scheme 25). ${ }^{48}$<smiles>c1ccc2[nH]nnc2c1</smiles>

$53 \mathrm{H}$

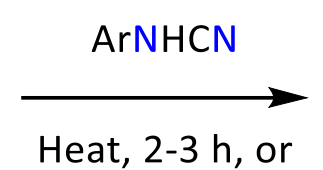

MW, 5-15 $\min$<smiles>NC(=[W])n1nnc2ccccc21</smiles>

Scheme 25. Synthesis of amidines 54.

\subsection{Amidines from aminopyrazoles}

5-Amino-1,3-diphenylpyrazole (55) was reacted with various amide solvents, such as $N, N$-dimethylformamide (DMF), 1-pyrrolidinecarboxaldehyde, and 1-piperidinecarboxaldehyde under microwave heating gave the amidine aldehyde products 56 in 91-96\% yields (Scheme 26). ${ }^{49}$ However, in other amide solvents, including $N$ methylacetamide, $N$-methylformamide, $N$-methylpropanamide, $N, N$-dimethylbenzamide, the simple amidination products 57 were formed, again in good yields (Scheme 26). ${ }^{49}$

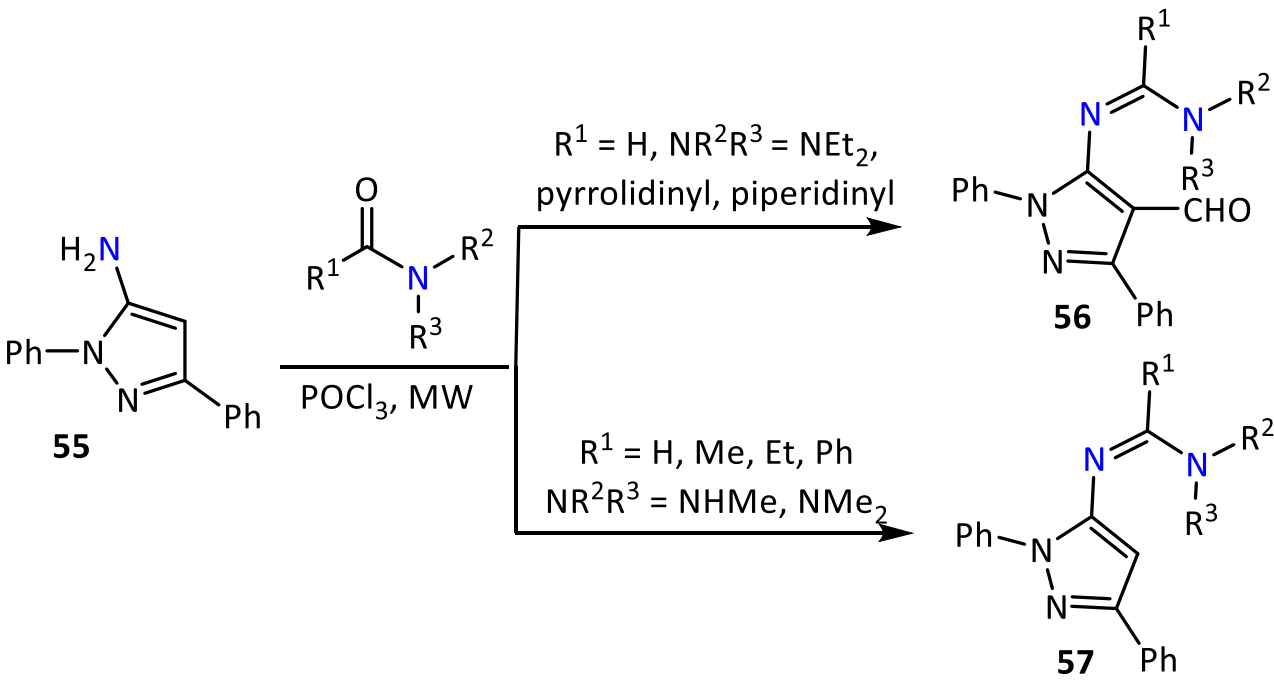

Scheme 26. Synthesis of amidines 56 and 57.

\subsection{Amidines by arylation of amidine salts}

Copper-catalyzed cross-coupling reactions of amidine salts $7 \mathbf{7} . \mathrm{HCl}$ with aryl iodides $\mathbf{4 5}$ gave monoarylated amidines $7 \mathrm{~J}$ in either DMF or acetonitrile as the solvent as shown in Scheme $27 .{ }^{50}$ 


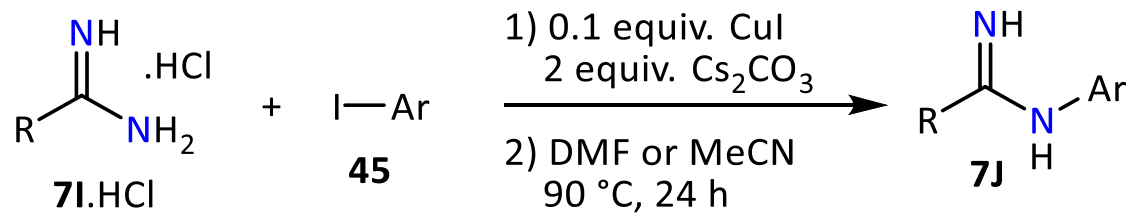

Scheme 27. Arylation of amidine salts using $\mathrm{Cul} / \mathrm{Cs}_{2} \mathrm{CO}_{3}$.

Similarly, Pd-catalyzed $\mathrm{N}$-arylation of both aryl- and alkyl-amidine salts by aryl halides $\mathrm{X}(\mathrm{X}=\mathrm{Cl}, \mathrm{Br}, \mathrm{I})$ is shown in (Scheme 28). ${ }^{51}$

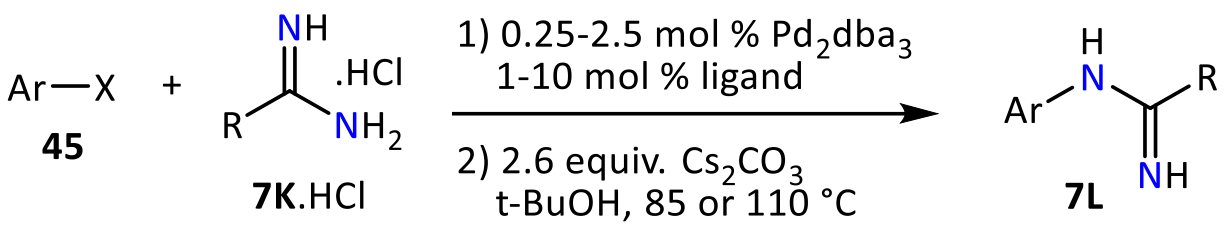

Scheme 28. Arylation of amidine salts using Pd-catalyst.

\subsection{Amidines by reaction of isothiocyanates with secondary amines}

A series of 1-aryl-2-phenyl-4-piperidino-4-thioalkyl-1,3-diazabuta-1,3-dienes 60 was conveniently prepared starting from $\mathrm{N}$-arylbenzimidoyl isothiocyanates $\mathbf{5 8} ; .^{52-54}$ Reaction first with secondary amines such as piperidine gave good yields of $N$-aryl- $N$ '-(piperidin-1-yl-thiocarbonyl)benzamidines 59, commonly referred to as thioureas. The alkylation of these thioureas with alkyl iodides resulted in excellent yields of amidines $\mathbf{6 0}$ (Scheme 29). ${ }^{55}$
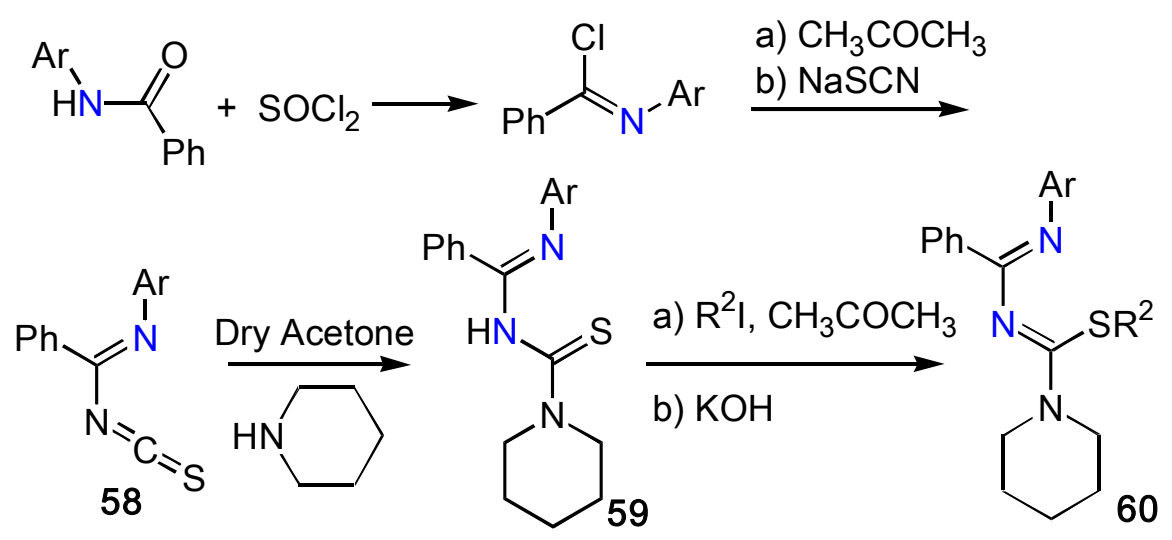

Scheme 29. Synthesis of amidines 60.

\section{Synthesis of Various Classes of Amidine}

\subsection{Synthesis of amidoximes}

Reaction of amides 61 with phosphorus pentachloride $\left(\mathrm{PCl}_{5}\right)$ in dichloromethane produced imidoyl chlorides 62 (Scheme 30). On treatment of 62 with $\mathrm{O}$-(trimethylsilyl)hydroxylamine $\left(\mathrm{H}_{2} \mathrm{NOTMS}\right)$, the reaction yielded the corresponding amidoximes 63 (Scheme 30). ${ }^{56}$ 
<smiles>[R]c1ccc(C(=O)Nc2ccncc2)c(F)c1</smiles>

Scheme 30. Synthesis of amidines 63.

\subsection{Synthesis of polysubstituted amidines}

Microwave reactions of primary and secondary amines with imidoylbenzotriazoles (imidoyl-Bt) gave various $N, N^{\prime}$-di- and $N, N^{\prime}, N^{\prime}$-trisubstituted amidines $7 \mathrm{~L}$ in good yields as shown in Scheme $31 .{ }^{57}$

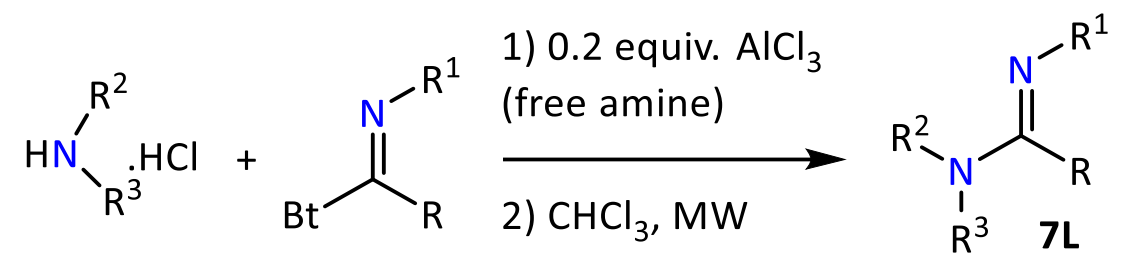

Scheme 31. Synthesis of $N, N^{\prime}$-di- and $N, N^{\prime}, N^{\prime}$-trisubstituted amidines 7L.

\subsection{Synthesis of acetamidines}

Reaction of primary amines, as shown in Scheme 32, with $N, N$-dimethylacetamide dimethylacetal in the presence of excess dimethyl amine, yielded acetamidines $64 .^{58}$

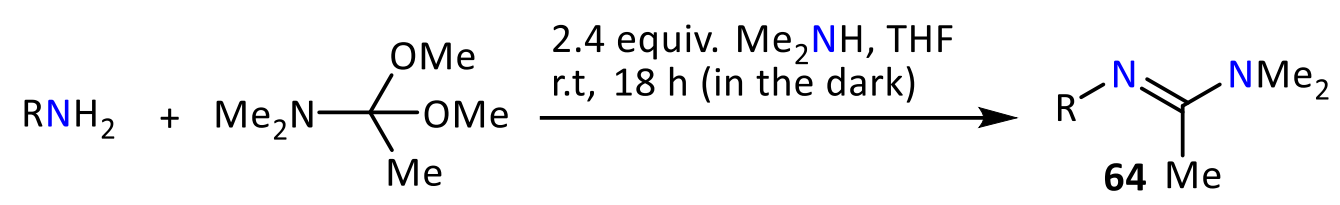

Scheme 32. Synthesis of amidines 64.

Sulfonamide 65a-g reacted with excess of a secondary amines or its salts in a dipolar aprotic medium in the presence of inorganic bases gave $N, N$-dialkyl- $N$-arylsulfonyl-( $\alpha$-dialkylamino- $\alpha$-aryl)acetamidines $64 a-k$ (Scheme 33). ${ }^{59}$ 


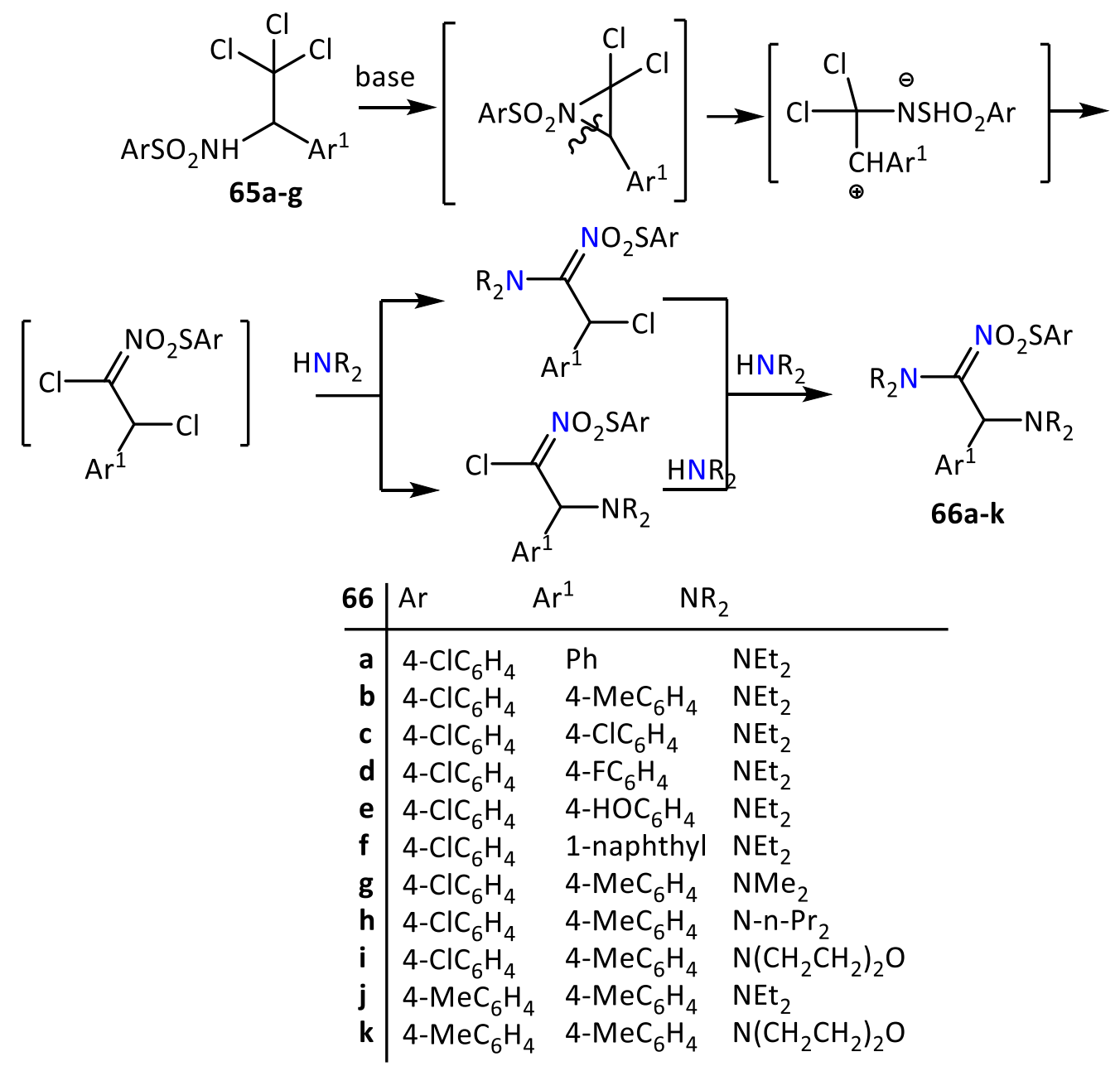

Scheme 33. Synthesis of acetamidines 66a-k.

\subsection{Synthesis of $\mathbf{N}$-sulfonyl amidines}

lodide ions catalyze the direct condensation of sulfonamides 67 and formamides furnishing $N$-sulfonyl formamidines 68 in good yields (Scheme 34). ${ }^{60}$

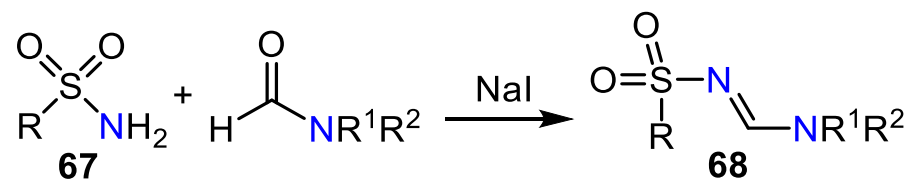

Scheme 34. Synthesis of $N$-sulfonyl amidines 68.

A catalyst-free hydroamination of $N, N$-disulfonyl ynamides 69 with amines gives $N$-sulfonylamidines 70 (Scheme 35). ${ }^{61}$ 

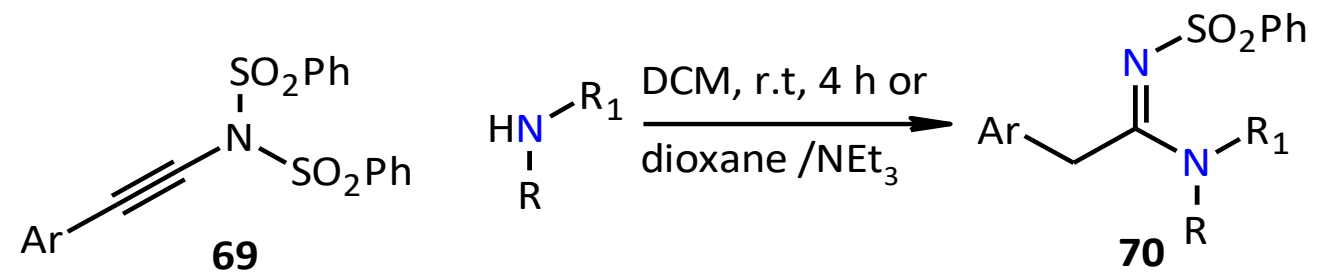

Scheme 35. Synthesis of $N$-sulfonyl amidines $\mathbf{7 0 .}$

Sulfonyl amidines $\mathbf{7 2}$ were synthesized from alkynes, amines and sulfonyl azide $\mathbf{7 1}$ in the presence of Cul catalyst at r.t. in 66-99\% yields (Scheme 36). ${ }^{62}$ The intermediate triazoles release nitrogen to produce sulfonyl iminoketenes which react with amines to give the target molecules.

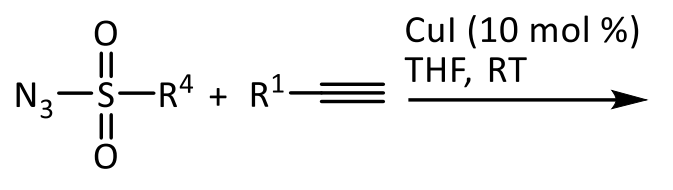

71<smiles>[R]c1nnn(S([R])(=O)=O)c1[Ge](C)([O])Cl</smiles>

[Cu]<smiles>[R]CC(CCCC)=NN[R]</smiles>

72

Scheme 36. Synthesis $N$-sulfonyl amidines 72.

Sulfonyl amidines $\mathbf{7 4}$ were synthesized from sulfonylamides $\mathbf{7 3}$ by one-pot diazo-transfer and intermolecular copper (I)-catalyzed reaction with alkynes (Scheme 37). ${ }^{63,64}$

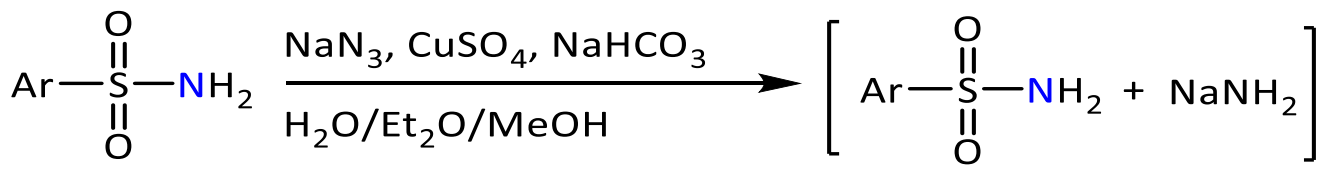

73
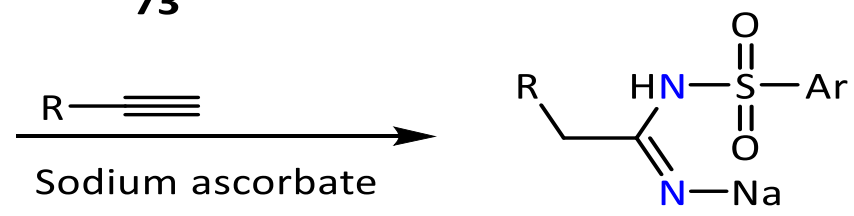

74

Scheme 37. Synthesis of $N$-sulfonyl amidines 74.

\subsection{Synthesis of $\mathbf{N}$-imidoylsulfinylformamidines}

$\mathrm{N}$-Imidoylsulfinylformamidines $\mathbf{7 6}$ were obtained by the reaction of a sulfinamide $\mathbf{7 5}$ with trimethyl orthoformate, followed by reaction with the lithium salt of $N$-methylaniline (Scheme 38). ${ }^{65,66}$ 


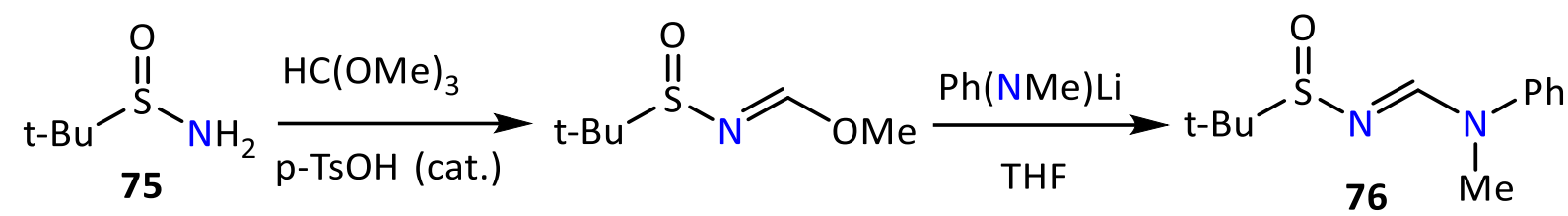

Scheme 38. Synthesis of $N$-imidoylsulfinformamidines.

\subsection{Synthesis of phosphoryl amidines}

Reaction of phosphoryl azide $\mathbf{7 7}$ with alkynes in the presence of Cul/THF mixture (Scheme 39), produced a triazolo-Cu complex $\mathbf{7 8}$ as intermediate (Scheme 38). Rearrangement of $\mathbf{7 8}$ accompanied with elimination of nitrogen gave 79 as a tentative intermediate. Addition of amines as one-pot synthesis gave phosphoryl amidines 80 (Scheme 39). ${ }^{67}$

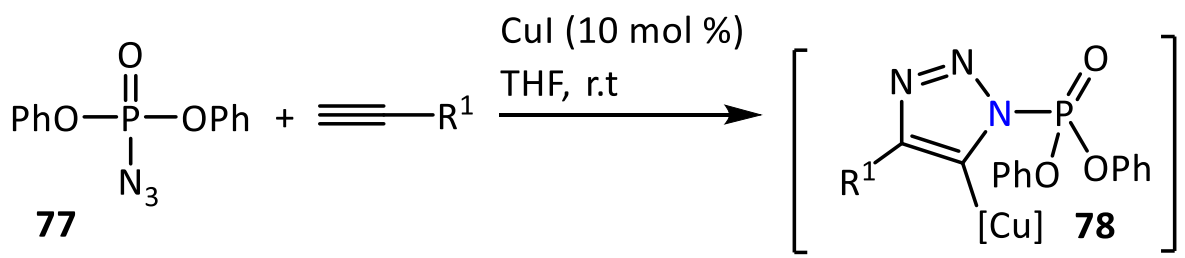<smiles>[R]C/C(=N\P(=O)(Oc1ccccc1)N([R])[R10])N([R1])CCCC</smiles>

Scheme 39. Synthesis of phosphoryl amidines $\mathbf{8 0 .}$

When phosphazene $\mathbf{8 1}$ was treated with benzoyl chloride in THF at room temperature, ${ }^{68}$ the reaction proceeded via intramolecular loss of triphenylphosphane oxide, ${ }^{69}$ to give unstable imidoyl chloride $\mathbf{8 3}$ (Scheme 40). The addition of amines in the presence of triethylamine then gave $\mathrm{N}$-(phosphorylalkyl)amidines 84 (Scheme 40). ${ }^{70}$

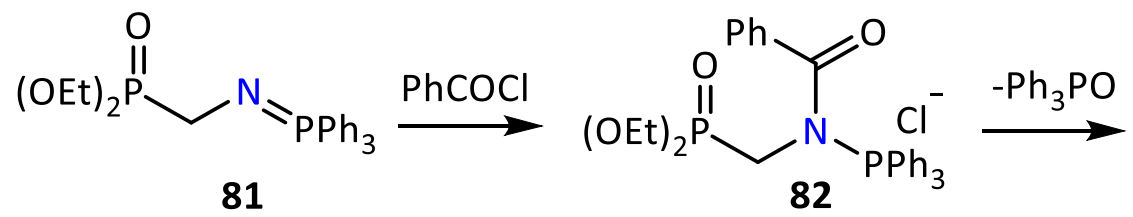

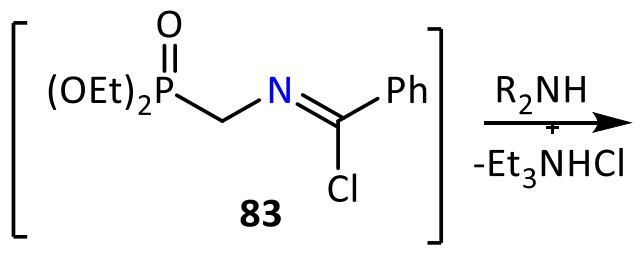<smiles>[R2]NC(=NCP=O)c1ccccc1</smiles>

Scheme 40. Synthesis of phosphoryl amidines 84 . 


\subsection{Synthesis of $\mathbf{N}, \boldsymbol{N}$-substituted amidines}

It is known that addition of $\mathrm{N}$-chlorosuccinimide (NCS) to the $p$-substituted benzaldoximes gives directly the corresponding benzhydroxamic acid chlorides 52, which on treatment with substituted hydroxylamines produce $\mathrm{N}, \mathrm{N}$-substituted amidines $85-90$ (Scheme 41 ). ${ }^{71,72}$

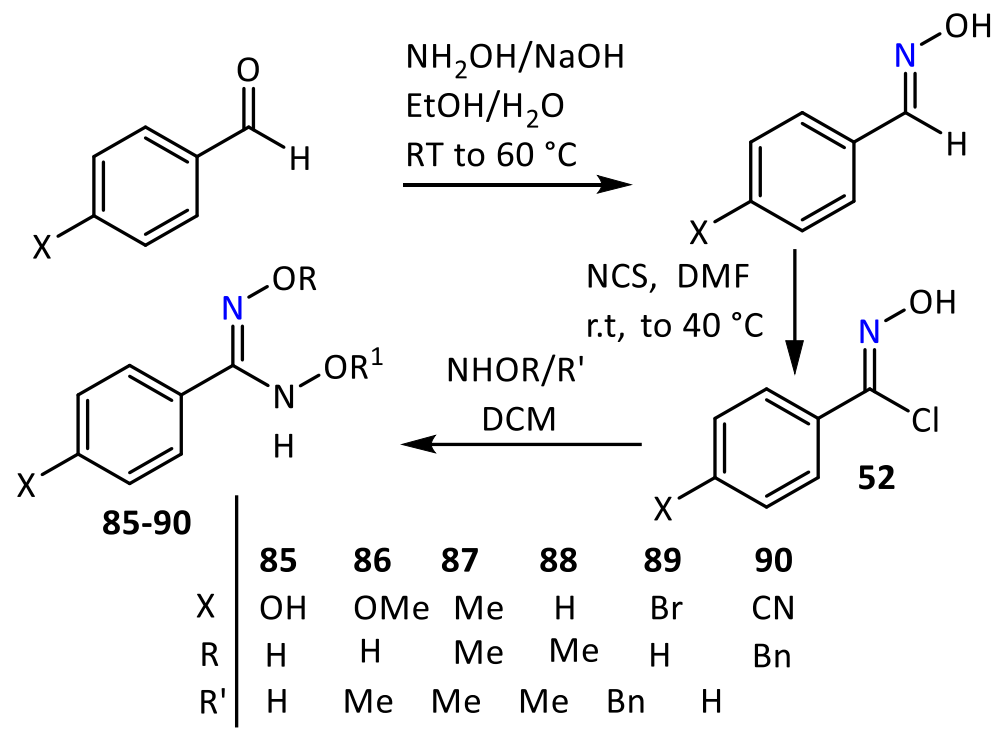

Scheme 41. Synthesis of $N, N^{\prime}$-substituted amidines 85-90.

\subsection{Synthesis of $\alpha, \beta$-unsaturated amidines}

Unsaturated amidines can be synthesized by coupling reaction between 0 -bromostyrene 91 with tertbutylisocyanide and pyrrolidine using the same conditions developed for coupling of aryl bromides $(5 \mathrm{~mol} \%$ $\mathrm{PdCl}_{2}, 10$ mol\% [1,1'-bis(diphenylphosphino)ferrocene (dppf), $\mathrm{Cs}_{2} \mathrm{CO}_{3}$, toluene). The desired amidine 92 was obtained in excellent yield (Scheme 42$).{ }^{73}$

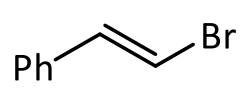

91
1) t-BuNC,

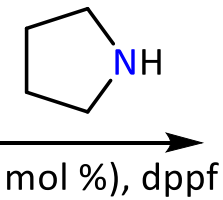

2) $\mathrm{PdCl}_{2}(5 \mathrm{~mol} \%), \mathrm{dppf}$
(10 $\mathrm{mol} \%) \mathrm{Cs}_{2} \mathrm{CO}_{3}, 65^{\circ} \mathrm{C}$, toluene

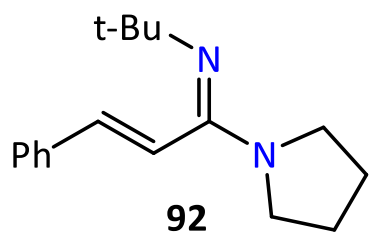

92

Scheme 42. Synthesis of $\alpha, \beta$-unsaturated amidines 92 .

Under similar conditions, the reaction of $\alpha$-bromostyrene (93) with tert-butylisocyanide and pyrrolidine or piperidine produced the isomeric methylidine amidines $\mathbf{9 4 a} \mathbf{b} \mathbf{b}$ (Scheme 43 ). ${ }^{63}$ 


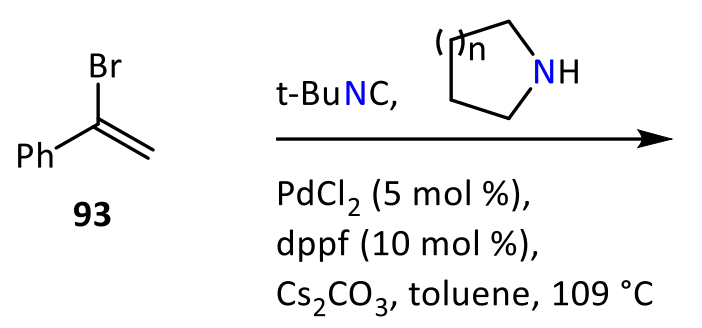<smiles>C=C(C(=[NH2+])N1CCNC1)c1ccccc1</smiles>

94a, $n=1$

94b, $n=2$

Scheme 43. Synthesis of $\alpha, \beta$-unsaturated amidines $94 a, b$.

\subsection{Utility of nano-catalysis in the synthesis of amidine}

Amidines $\mathbf{7 M}$ have been synthesized rapidly and in high yields from $\mathrm{N}$-arylamides using Nano-MgO using solvent-free reaction condition (SFRC) as shown in Scheme $44 .{ }^{74}$ It should be noted that these conditions suppress the transamidation.

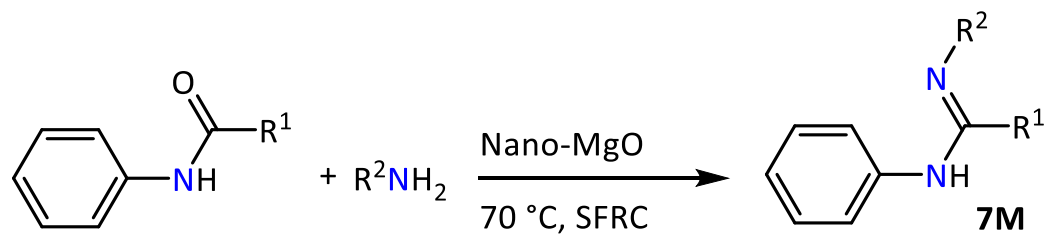

Scheme 44. Nano-catalysis in amidine synthesis

\subsection{Amidines through one-pot three component reactions}

Reaction of an isocyanide ( $1 \mathrm{mmol})$, an aldehyde $(1 \mathrm{mmol})$, and an amine $(2 \mathrm{mmol})$ using $1 \mathrm{~mol} \%$ of molecular iodine in methanol, gave amidines 95 in good yields (Scheme 45). ${ }^{75}$

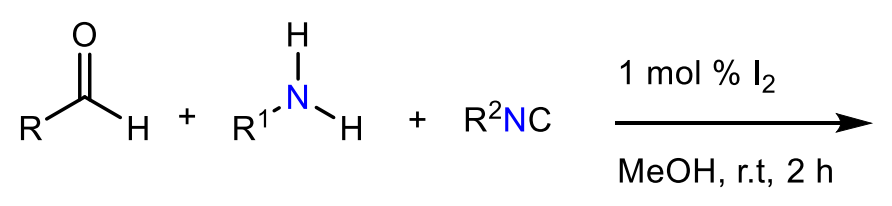<smiles>[R]N=C(N[R])C([R])N[R1]</smiles>

\begin{tabular}{|c|c|c|c|c|}
\hline 95 & $\mathrm{R}$ & $\mathrm{R}^{1}$ & $\mathrm{R}^{2}$ & Yield \% \\
\hline $\mathbf{a}$ & $\mathrm{C}_{6} \mathrm{H}_{5}$ & $\mathrm{C}_{6} \mathrm{H}_{5}$ & $\left(\mathrm{CH}_{3}\right)_{3} \mathrm{C}$ & 90 \\
\hline b & $\mathrm{C}_{6} \mathrm{H}_{5}$ & $\mathrm{C}_{6} \mathrm{H}_{5}$ & $c-\mathrm{C}_{6} \mathrm{H}_{11}$ & 93 \\
\hline c & 2- $\mathrm{Br}-\mathrm{C}_{6} \mathrm{H}_{4}$ & $\mathrm{C}_{6} \mathrm{H}_{5}$ & $\left(\mathrm{CH}_{3}\right)_{3} \mathrm{C}$ & 85 \\
\hline d & $c-\mathrm{C}_{6} \mathrm{H}_{11}$ & $\mathrm{C}_{6} \mathrm{H}_{5}$ & $c-\mathrm{C}_{6} \mathrm{H}_{11}$ & 86 \\
\hline e & $n-\mathrm{C}_{8} \mathrm{H}_{17}$ & $\mathrm{C}_{6} \mathrm{H}_{5}$ & $c-\mathrm{C}_{6} \mathrm{H}_{11}$ & 88 \\
\hline f & $4-\mathrm{Cl}-\mathrm{C}_{6} \mathrm{H}_{4}$ & $\mathrm{C}_{6} \mathrm{H}_{5}$ & $\left(\mathrm{CH}_{3}\right)_{3} \mathrm{C}$ & 88 \\
\hline $\mathbf{g}$ & 2-Furyl & $\mathrm{C}_{6} \mathrm{H}_{5}$ & $\left(\mathrm{CH}_{3}\right)_{3} \mathrm{C}$ & 90 \\
\hline h & $4-\mathrm{Cl}-\mathrm{C}_{6} \mathrm{H}_{4}$ & 4- $\mathrm{CH}_{3} \mathrm{O}-\mathrm{C}_{6} \mathrm{H}_{4}$ & $\left(\mathrm{CH}_{3}\right)_{3} \mathrm{C}$ & 90 \\
\hline j & $\mathrm{C}_{6} \mathrm{H}_{5}$ & $4-\mathrm{CH}_{3}-\mathrm{C}_{6} \mathrm{H}_{4}$ & $\left(\mathrm{CH}_{3}\right)_{3} \mathrm{C}$ & 86 \\
\hline i & $4-\mathrm{F}-\mathrm{C}_{6} \mathrm{H}_{4}$ & $4-\mathrm{CH}_{3}-\mathrm{C}_{6} \mathrm{H}_{4}$ & $\left(\mathrm{CH}_{3}\right)_{3} \mathrm{C}$ & 92 \\
\hline
\end{tabular}

Scheme 45. One-pot reaction for the formation of amidines 95. 


\subsection{Synthesis of $\mathbf{N}$-alkoxy amidine salts}

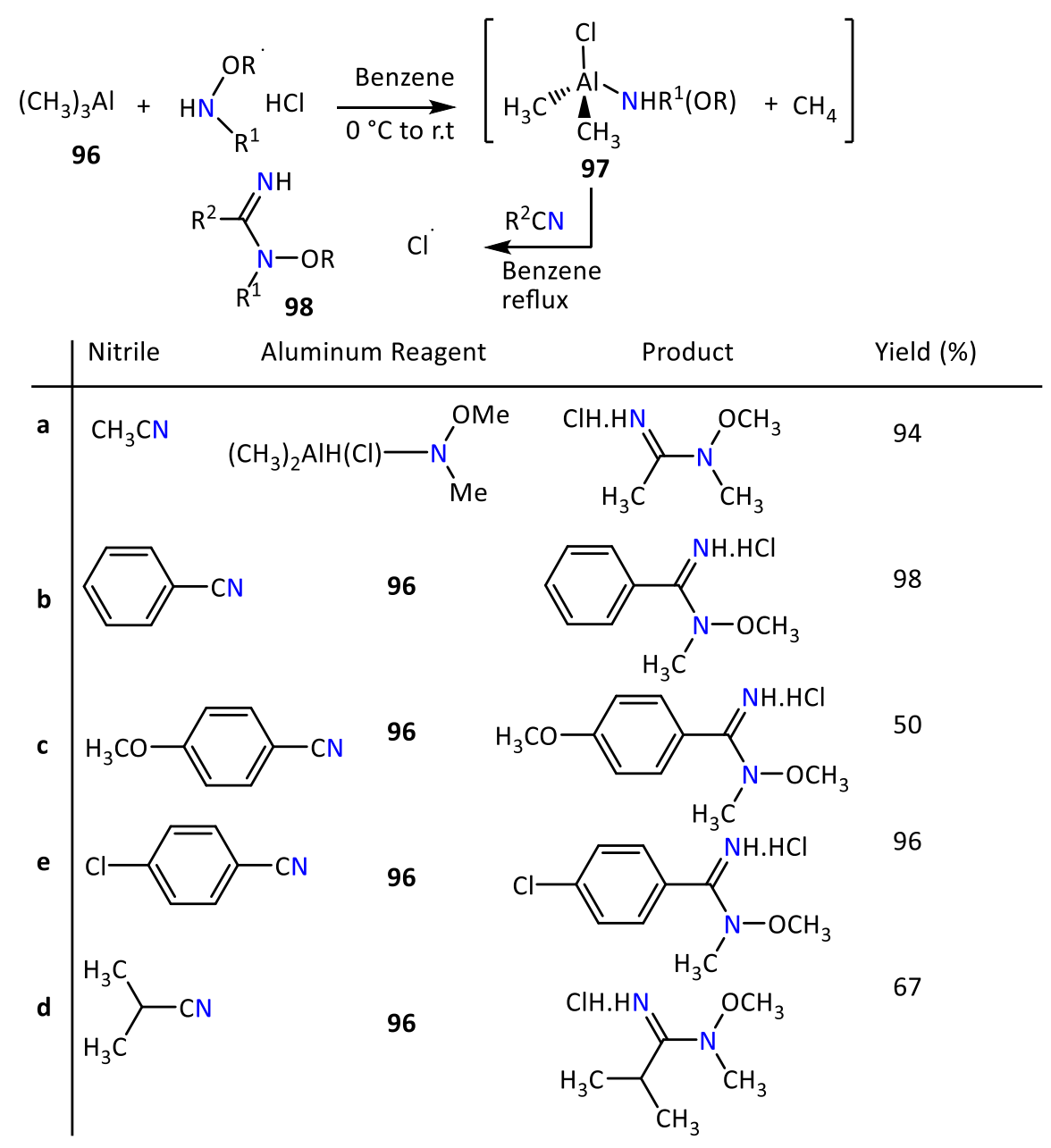

Scheme 46. Synthesis of $N$-alkoxy amidine salts 98.

Addition of trimethylaluminum (96) to alkoxyamine hydrochlorides gave ( $N$-alkyl- $N$-alkoxyamine)dimethylaluminum chlorides $\mathbf{9 7}$ as intermediates, which on addition to nitriles provided a good yield of the $N$ alkoxy amidine salts 98 (Scheme 46). ${ }^{76}$

\subsection{Synthesis of bisamidines}

Using successive double addition of primary diamines to the same equivalents of benzonitrile afforded bisamidines 99 as shown in Scheme $47 .{ }^{77}$ The latter were utilized in the synthesis of RNA with amidine linkage. ${ }^{77}$ 


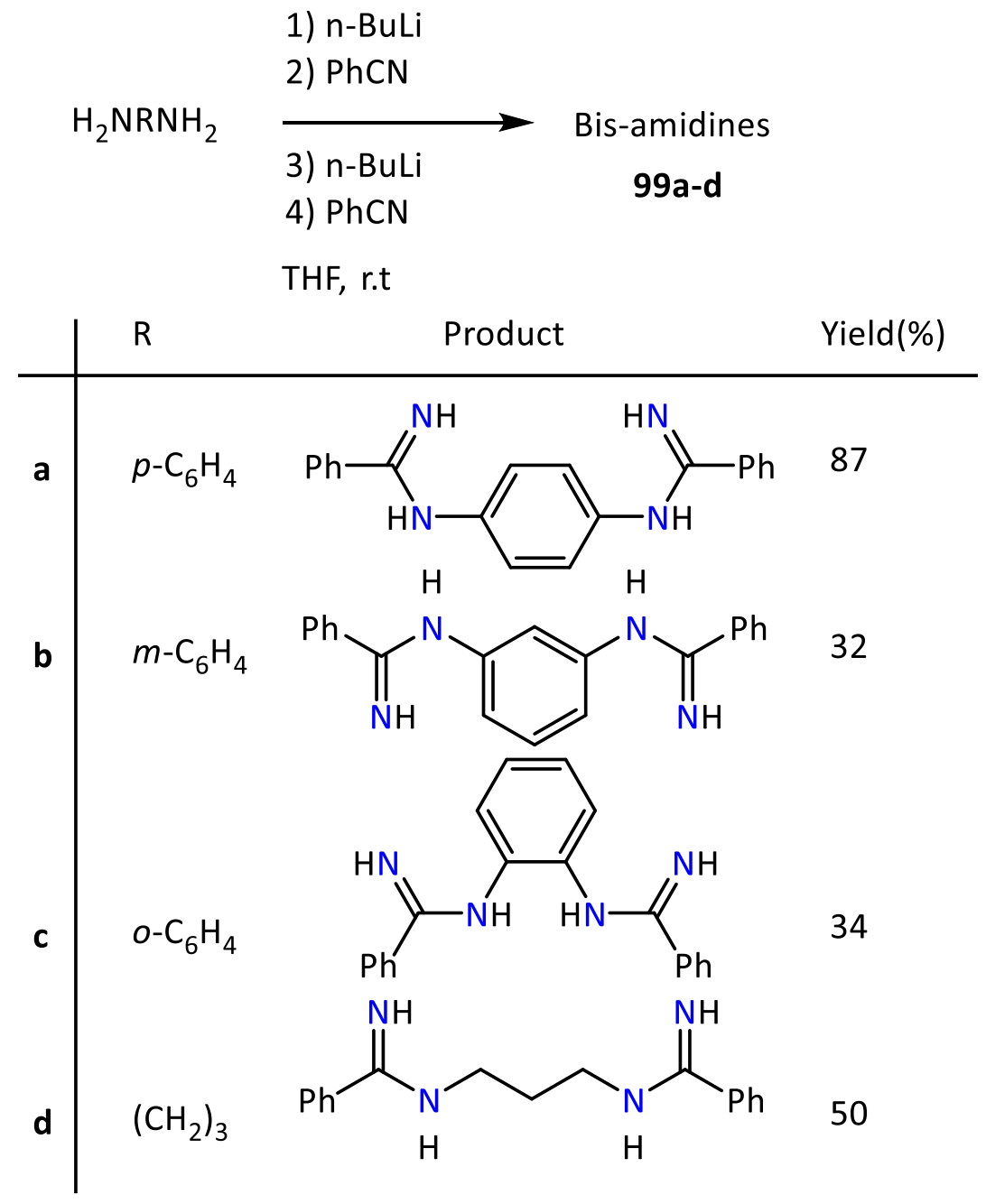

Scheme 47. Synthesis of bis amidines 99.

The strategy for the synthesis of $N$-substituted bisalkylamidines 100 is shown in Scheme $48 .{ }^{78,79}$<smiles>[R]NC(=N)CC[Y10](=N)NC(=N)Cl</smiles>

Scheme 48. Synthesis of bis amidines 100. Reagent and Condition: i) RX/DMF, MeONa, $25^{\circ} \mathrm{C}$, Overnight. ii) $\mathrm{H}_{2} / \mathrm{Pd}, 10 \% \mathrm{MeOH}, \mathrm{HCl} 3 \mathrm{~N}$, r.t, $4 \mathrm{hr}$ or $\mathrm{Zn}, \mathrm{MeOH} / \mathrm{AcOH}, 60^{\circ} \mathrm{C}, 3 \mathrm{~h}$.

The syntheses of dicationic molecules containing either diguanidino or reversed amidine cationic groups were achieved starting with 2,5 bis(tri- $n$-butylstannyl)furan 101 with arylbromides. ${ }^{80}$ Thus 2,5-bis(4- 
aminophenyl)furan analogues 102 were obtained in good yields. The reaction of 102 with S-(2-naphthylmethyl)thioimidates gave the reversed amidines 103 (Scheme 49). ${ }^{81}$

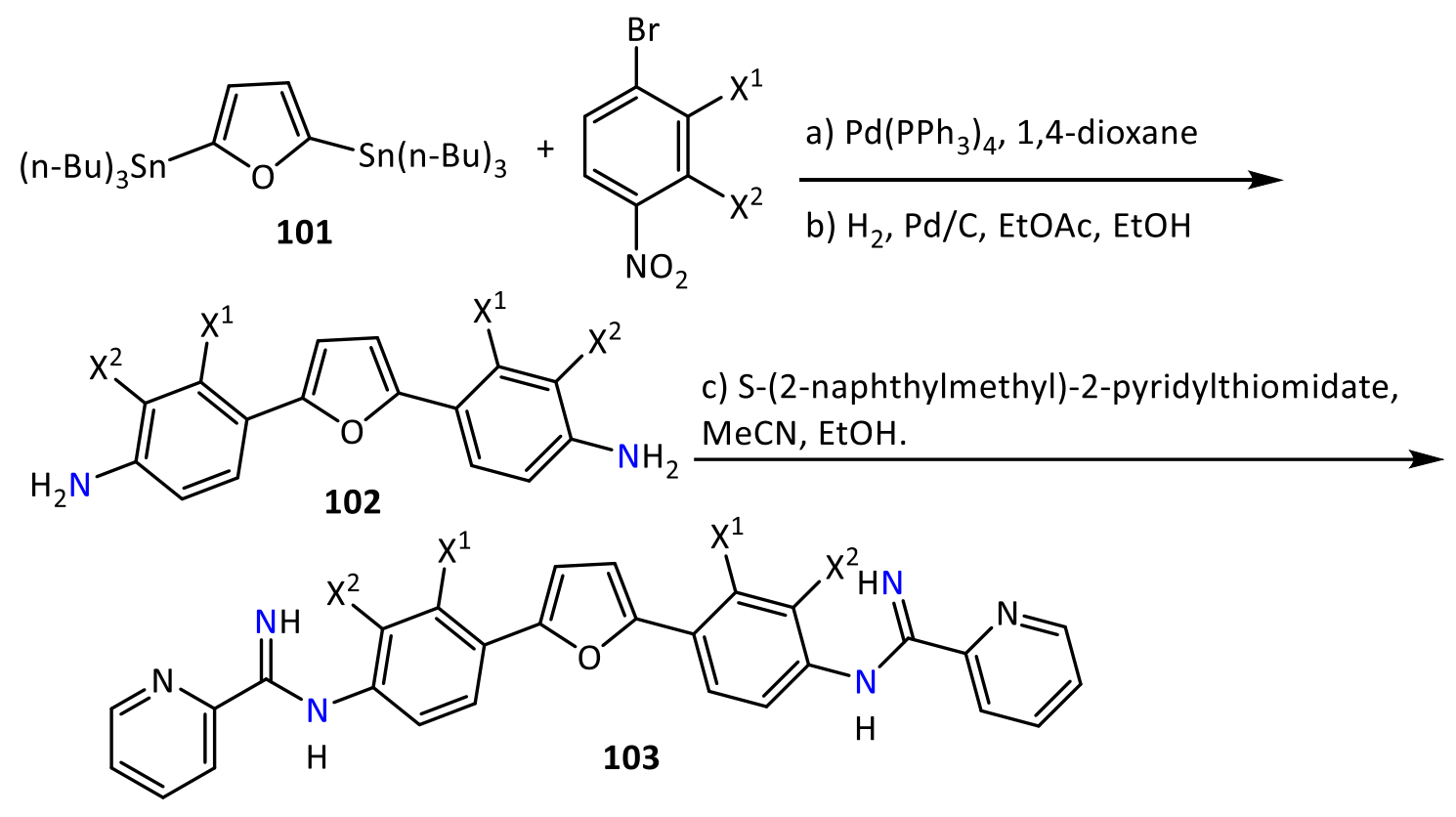

Scheme 49. Synthesis of bisamidines 103.

Diphenylsulfimide $\left(\mathrm{Ph}_{2} \mathrm{~S}=\mathrm{NH}, 104\right)$ reacts with nitrile-coordinated platinum complexes 105 to give platinum bisamidine complexes 106 (Scheme 50). ${ }^{82}$<smiles>[R]N[P+]([R16])(Cl)(Cl)(Cl)(Cl)(Cl)Cl</smiles>

104

105

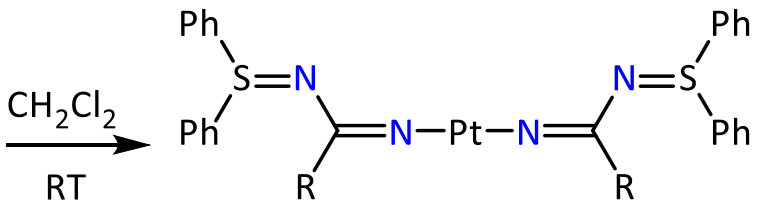

106

$\mathrm{R}=\mathrm{Me}, \mathrm{Et}, \mathrm{PhCH}_{2}$

Scheme 50. Synthesis of bisamidines 106.

When 1,4-dibromobenzene reacted with two equivalents of butyllithium, a double metal halogen exchange reaction occurred, and subsequent reaction with two molecules of dicyclohexylcarbodiimide (DDC) followed by silylation (i.e. TMSCl) produced the bis-silylated amidine 107 (Scheme 51). ${ }^{83,84}$ 
<smiles></smiles>

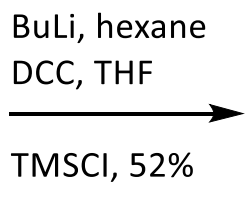<smiles>CCCCN(C(=NC1CCCCC1)c1ccc(C(=NC2CCCCC2)[N+](C)(C)C2CCCCC2)cc1)C1CCCCC1</smiles>

Scheme 51. Synthesis of bisamidines 107.

\subsection{Synthesis of cyclic amidines}

4.13.1. Synthesis of monocyclic amidines. A simple and efficient microwave-based protocol for the synthesis of heterocyclic amidine started with ethyl polyphosphate ester (PPE) promoted cyclodehydration of $N$-aryl- $N^{\prime}$ acylalkylenediamines 109 (Scheme 52). That method has been considered general for five- to eight-membered heterocycles and affords high yields of the desired products in remarkably short reaction time (Scheme 52). ${ }^{85}$

$N, N^{\prime}$-Dihydroxybenzimidamide (110) was prepared using a literature procedure. ${ }^{85}$ The condensation between $p$-unsubstituted $\mathbf{1 1 0}$ and ketones led to three new cyclic $N, N^{\prime}$-dihydroxybenzamidine derivatives, the 1,2,4-oxadiazolines 111-113 (Scheme 53). These decomposed after few hours on storage as the concentrated crude product mixtures. However, immediate flash chromatography led to pure substances of 111-113 (Scheme 53)..$^{85}$

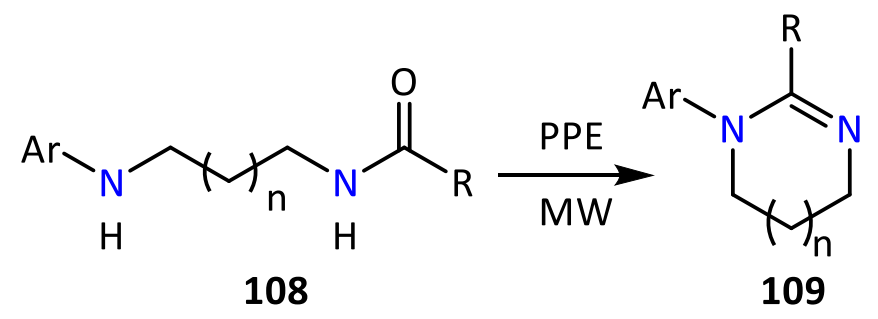

\begin{tabular}{c|cccc|cccc}
$\mathbf{1 0 9}$ & $\mathrm{Ar}$ & $\mathrm{R}$ & $\mathbf{n}$ & & $\mathbf{1 0 9}$ & $\mathrm{Ar}$ & $\mathrm{R}$ & $\mathrm{n}$ \\
\hline $\mathbf{a}$ & $4-\mathrm{ClC}_{6} \mathrm{H}_{4}$ & $\mathrm{Et}$ & 1 & & $\mathbf{h}$ & $2-\mathrm{O}_{2} \mathrm{NC}_{6} \mathrm{H}_{4}$ & $t-\mathrm{Bu}$ & 0 \\
$\mathbf{b}$ & $4-\mathrm{ClC}_{6} \mathrm{H}_{4}$ & $\mathrm{Et}$ & 1 & & $\mathbf{i}$ & 1-naphthyl & $\mathrm{C}_{6} \mathrm{H}_{5}$ & 0 \\
$\mathbf{c}$ & $4-\mathrm{O}_{2} \mathrm{NC}_{6} \mathrm{H}_{4}$ & $\mathrm{Et}$ & 1 & $\mathbf{j}$ & $2-\mathrm{O}_{2} \mathrm{NC}_{6} \mathrm{H}_{4}$ & $\mathrm{Et}$ & 2 \\
$\mathbf{d}$ & $4-\mathrm{O}_{2} \mathrm{NC}_{6} \mathrm{H}_{4}$ & $t-\mathrm{Bu}$ & 1 & $\mathbf{k}$ & $4-\mathrm{BrC}_{6} \mathrm{H}_{4}$ & $\mathrm{C}_{6} \mathrm{H}_{5}$ & 2 \\
$\mathbf{e}$ & $2,4,6-\mathrm{Me}_{3} \mathrm{C}_{6} \mathrm{H}_{2}$ & $\mathrm{Et}$ & 1 & $\mathbf{I}$ & 1-naphthyl & $t-\mathrm{Bu}$ & 2 \\
$\mathbf{f}$ & $\mathrm{C}_{6} \mathrm{H}_{5}$ & $\mathrm{C}_{6} \mathrm{H}_{5} \mathrm{C}_{2} \mathrm{H}_{4}$ & 1 & $\mathbf{m}$ & $\mathrm{C}_{6} \mathrm{H}_{5}$ & $\mathrm{C}_{6} \mathrm{H}_{5}$ & 3 \\
$\mathbf{g}$ & $2-\mathrm{O}_{2} \mathrm{NC}_{6} \mathrm{H}_{4}$ & $\mathrm{C}_{6} \mathrm{H}_{5}$ & 0 & $\mathbf{n}$ & $4-\mathrm{CH}_{3} \mathrm{C}_{6} \mathrm{H}_{4}$ & $\mathrm{C}_{6} \mathrm{H}_{5}$ & 3
\end{tabular}

Scheme 52. Synthesis of monocyclic amidines 109. 
<smiles>O/N=C(\NO)c1ccccc1</smiles>

110

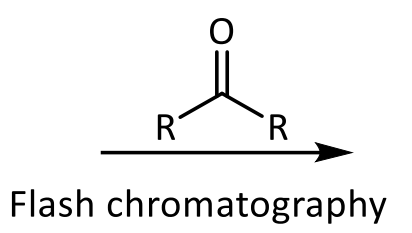<smiles>[R]C1([R])ON=C(c2ccccc2)N1O</smiles>

111-113

$$
\text { 111: } \mathrm{R}, \mathrm{R}=\mathrm{Me} ; 112: \mathrm{R}, \mathrm{R}=-\left(\mathrm{CH}_{2}\right)_{4}^{-} ; 113: \mathrm{R}, \mathrm{R}=-\left(\mathrm{CH}_{2}\right)_{5}^{-}
$$

Scheme 53. Synthesis of monocyclic amidines 111-113.

4.13.2. Synthesis of bicyclic amidines. In amides $\mathbf{1 1 4}$ the azido group serves as a nucleophile or a 1,3-dipole that undergoes cyclization with an activated amide moiety, followed by the extrusion of molecular nitrogen to afford the bicyclic amidine. Thus, bicyclic amidines 115 were obtained during the reaction of 114a-k with oxalyl halides (Scheme 54). ${ }^{86}$

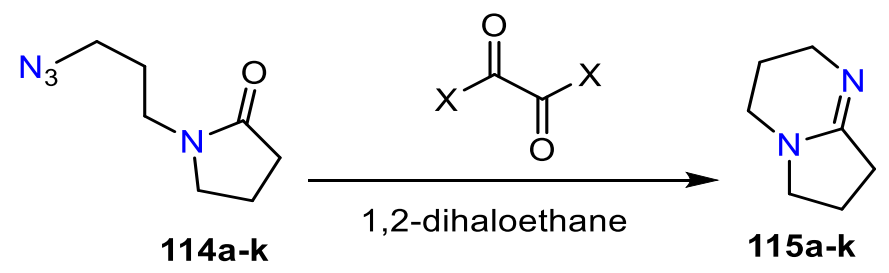

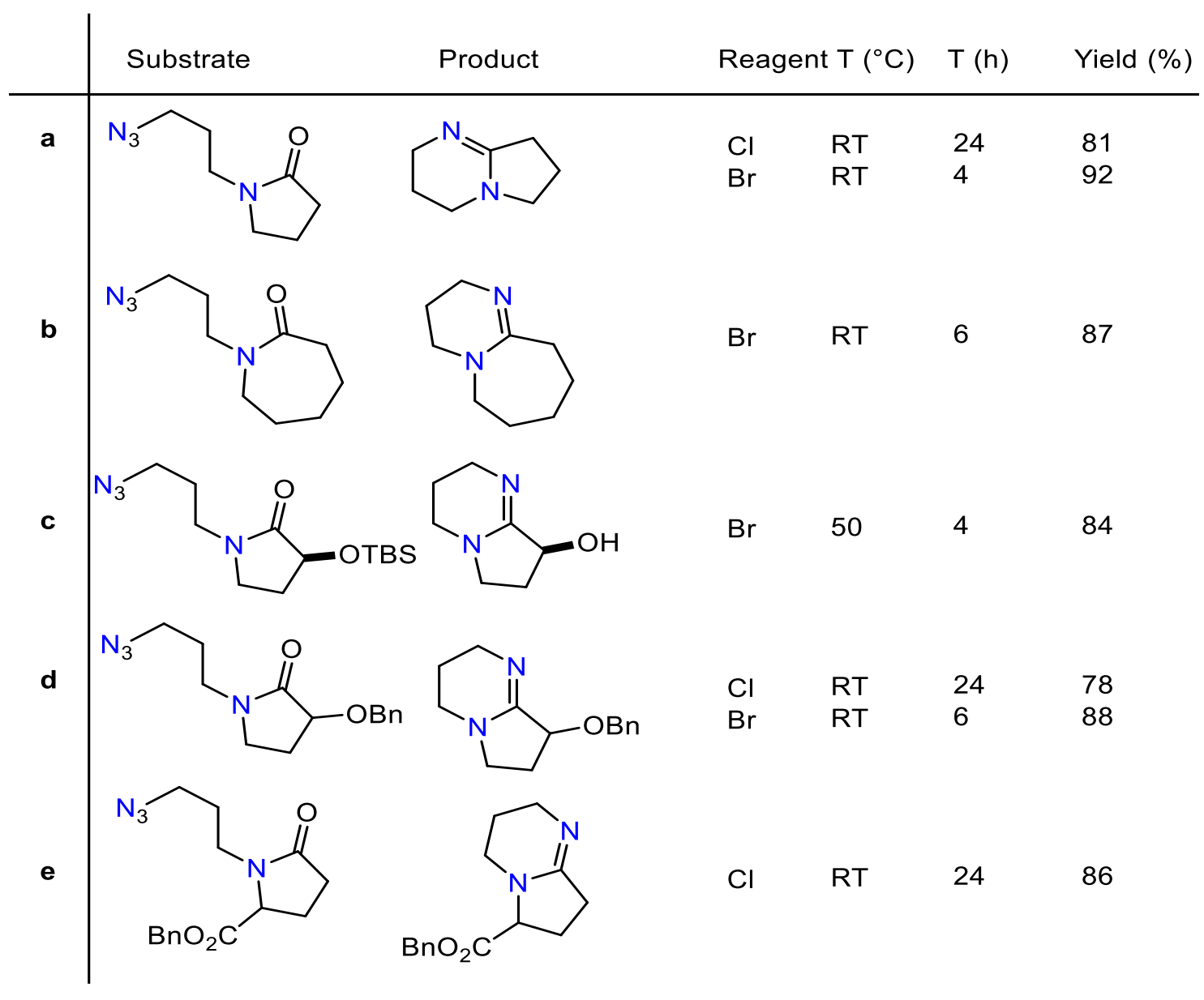

Scheme 54. Synthesis of bicyclic amidines 115. 


\section{Chemical Reactions of Amidines}

\subsection{Addition of amidines to electrophiles}

Amidines can serve as reactive nitrogen nucleophiles and react with Michael acceptor to build a carbonnitrogen bond. Depending on the substrates and the reaction conditions, either $N$-alkylamidines are formed, or hydrolysis led to the formation of amides. An example of the latter is the reaction of diethyl 2(ferrocenylmethylidene)malonate $\mathbf{1 1 6}$ with excess of amidines $\mathbf{7 M}$ in aqueous ethanol in the presence of $\mathrm{Na}_{2} \mathrm{CO}_{3}$ at $80-85{ }^{\circ} \mathrm{C}$ to afford products 117a-e (Scheme 55$) .87$

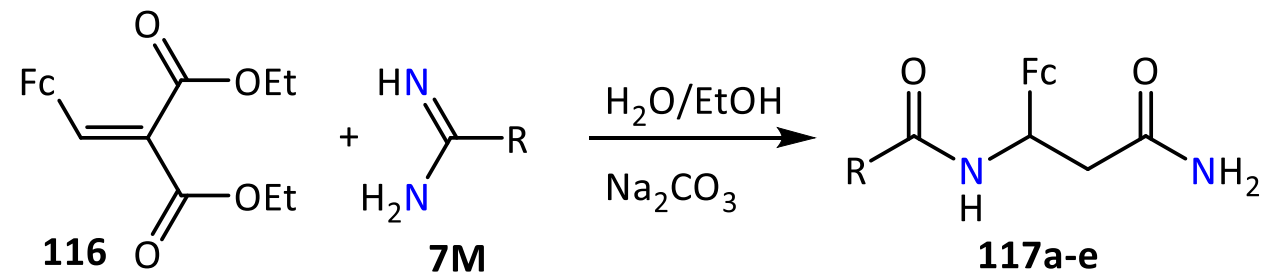

$$
\text { 117: } a, R=M e ; b, R=P h ; c, R=N_{2} ; d, R=N_{2} e_{2} ; e, R=O M e . F c=C_{5} H_{5} F C_{5} H_{4}
$$

Scheme 55. Addition of amidines to electrophiles.

\subsection{Synthesis of heterocyclic derivatives}

Cyclization is the most important reactions of functionalized and unfunctionalized amidines; thereby different heterocyclic compounds containing the $-\mathrm{N}=\mathrm{C}-\mathrm{N}=$ group are obtained. In the next paragraphs, ordered by ring sizes, some examples are highlighted.

5.2.1. Synthesis of three-membered rings. Reaction of alkyl- or aryl-amidines $7 \mathrm{~N}$ with sodium hypochlorite in dimethyl sulfoxide (DMSO) solution afforded the corresponding 3-halodiazirenes 118 (Scheme 56). ${ }^{88}$

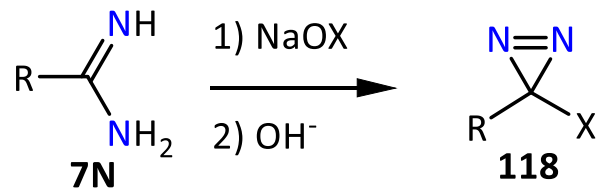

Scheme 56. Synthesis of diazirenes 118.

5.2.2. Synthesis of four-membered rings. Reaction of diphenylketene (119) with 4-(N-phenylformimidinoyl)morpholine (120) gave 1,3,3-triphenyl-4-morpholinoazetidinone (121) (Scheme 57). ${ }^{89}$

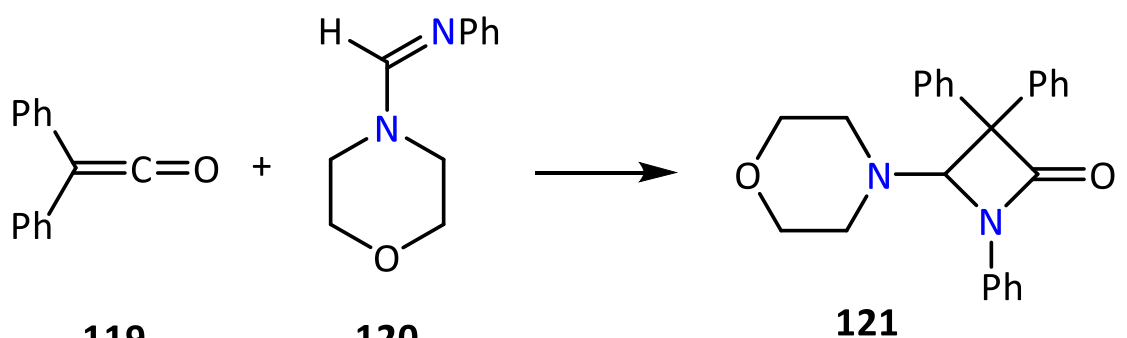

Scheme 57. Synthesis of azetidinone 121. 
5.2.3. Synthesis of five-membered rings. 5.2.3.1. Pyrroles. When a diglyme solution of the amidines 70 and ethyl-3-benzoylacrylate (122) was heated at $120^{\circ} \mathrm{C}, 3,4$-dihydropyrrol-2-one derivatives 123 were obtained (Scheme 58). ${ }^{90}$

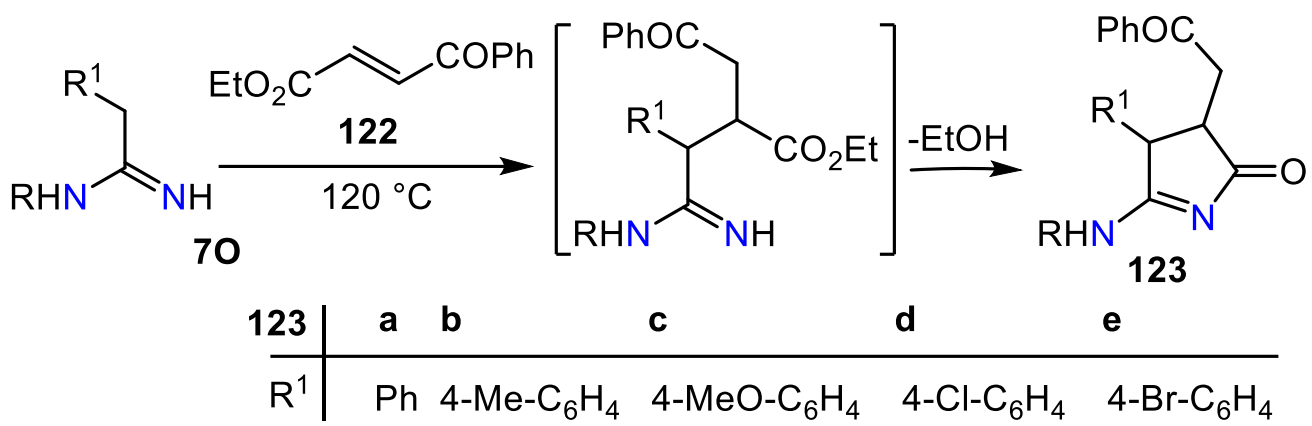

Scheme 58. Synthesis of pyrrolinones 123

Reaction of amidine-ylidines 124 with trimethyl ethylenetricarboxylate (125) afforded the 3,4-dihydropyrrol-2-ones 126 (Scheme 59). ${ }^{91}$

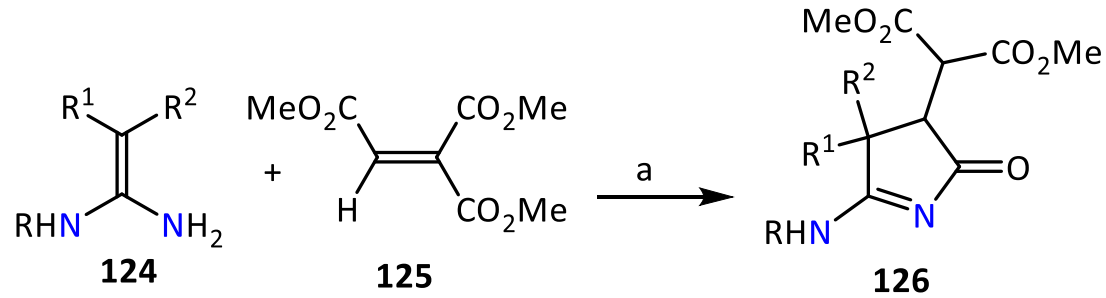

\begin{tabular}{r|llllllll}
126 & $\mathrm{a}$ & $\mathrm{b}$ & $\mathrm{c}$ & $\mathrm{d}$ & $\mathrm{e}$ & $\mathrm{f}$ & $\mathrm{g}$ & $\mathrm{h}$ \\
\hline $\mathrm{R}^{1}$ & $\mathrm{Ph}$ & $4-\mathrm{Cl}-\mathrm{C}_{6} \mathrm{H}_{4}$ & $4-\mathrm{Br}-\mathrm{C}_{6} \mathrm{H}_{4}$ & $4-\mathrm{MeO}-\mathrm{C}_{6} \mathrm{H}_{4}$ & $4-\mathrm{Me}-\mathrm{C}_{6} \mathrm{H}_{4}$ & $\mathrm{Ph}-\mathrm{CH}_{2}$ & $\mathrm{H}$ & $\mathrm{Me}$ \\
$\mathrm{R}^{2}$ & $\mathrm{H}$ & $\mathrm{H}$ & $\mathrm{H}$ & $\mathrm{H}$ & $\mathrm{H}$ & $\mathrm{H}$ & $\mathrm{H}$ & $\mathrm{Me}$ \\
Yield (\%) & 87 & 71 & 72 & 88 & 56 & 51 & 50 & 50
\end{tabular}

Scheme 59. Synthesis of dihydropyrrolinones 126.

Methyl 1,2,3,4-tetrahydropyrrolo[1,2-a]pyrimidine-7-ylideneacetates 129 were prepared by the reaction of 127 with dimethyl acetylenedicarboxylate (128) in methanol at room temperature (Scheme 60). ${ }^{87}$ The proposed mechanism for the formation of $\mathbf{1 2 9}$ is as shown in Scheme $60 .^{92}$

A new synthesis of 5,6,7-trichloro-3 $\alpha$-hydroxy-3-methyl-1-(4-nitrophenyl)-2-[(4-nitrophenyl)imino]1,2,3,3 $\alpha$-tetrahydro-4H-indol-4-one (134) was discovered in the reaction of nitro-substituted $N, N^{\prime}$ diarylamidine 7P with 3,4,5,6-tetrachloro-1,2-benzoquinone (130) (Scheme 61). ${ }^{93}$ The proposed mechanism to explain the formation of $\mathbf{1 3 4}$ is as follows. Nucleophilic attack on C-3 of $\mathbf{1 3 0}$ by the imino nitrogen atom $\mathrm{N}^{2}$ of 7P is followed by liberation of hydrogen chloride to give 131. Tautomerism of $\mathbf{1 3 1}$ to $\mathbf{1 3 2}$ followed by amidineene addition to form salt 133 (Scheme 61). Hydrogen transfer in 133 led ultimately to the formation of 134 (Scheme 61). ${ }^{93}$ 


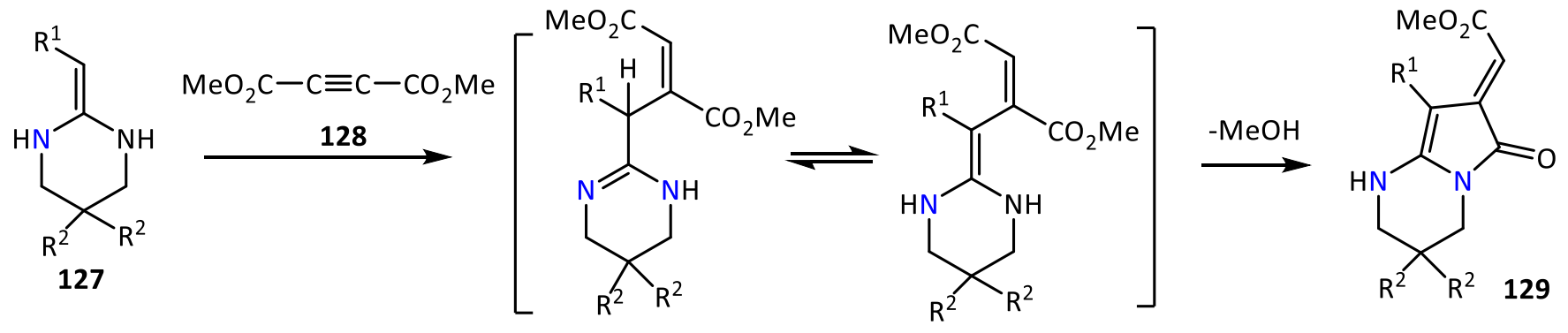

\begin{tabular}{r|cccccc}
129 & $\mathrm{a}$ & $\mathrm{b}$ & $\mathrm{c}$ & $\mathrm{d}$ & $\mathrm{e}$ & $\mathrm{f}$ \\
\hline $\mathrm{R}^{1}$ & $\mathrm{Ph}$ & $\mathrm{Ph}$ & $4-\mathrm{MeC}_{6} \mathrm{H}_{4}$ & $4-\mathrm{MeC}_{6} \mathrm{H}_{4}$ & $4-\mathrm{MeOC}_{6} \mathrm{H}_{4}$ & $4-\mathrm{MeOC}_{6} \mathrm{H}_{4}$ \\
$\mathrm{R}^{2}$ & $\mathrm{H}$ & $\mathrm{Me}$ & $\mathrm{H}$ & $\mathrm{Me}$ & $\mathrm{H}$ & $\mathrm{Me}$ \\
Yield (\%) & 43 & 55 & 44 & 60 & 37 & 41
\end{tabular}

Scheme 60. Synthesis of fused pyrrolidinones 129.

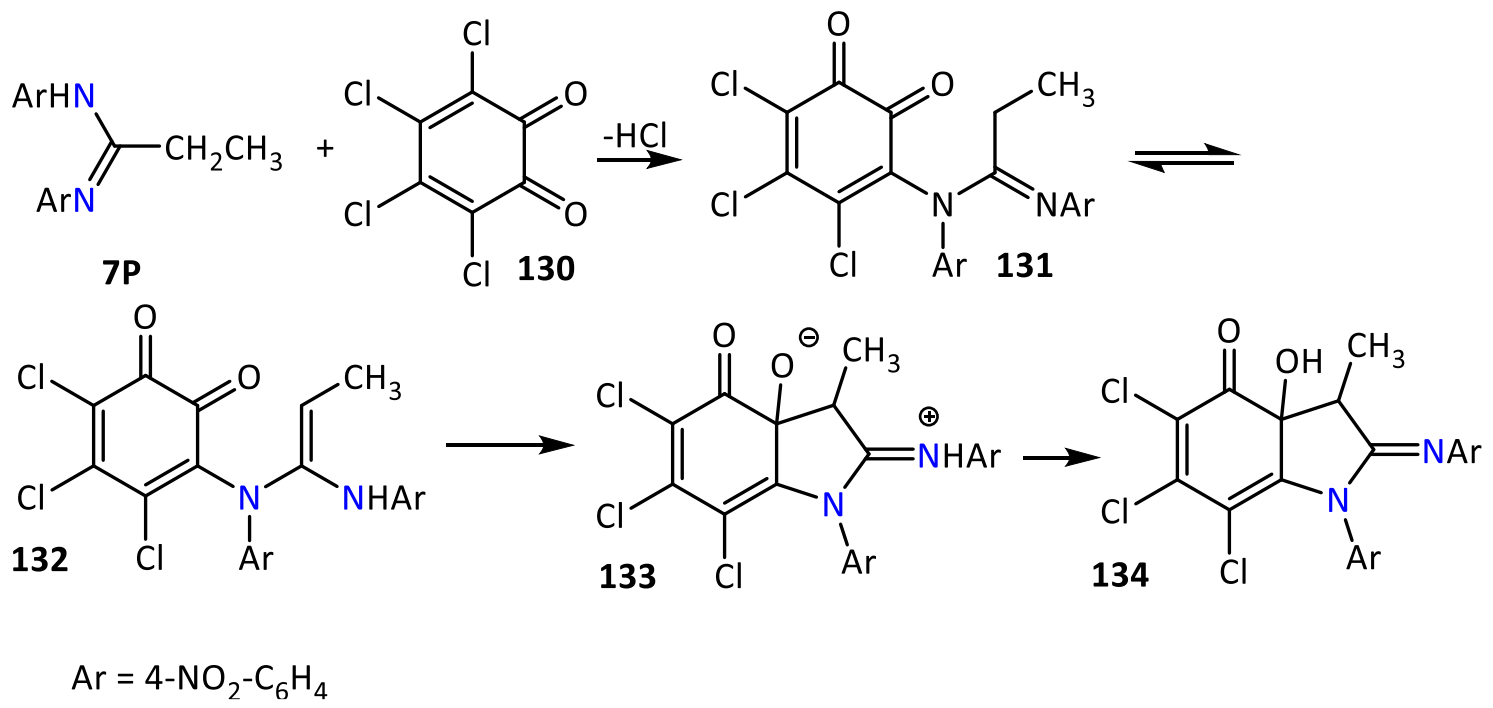

Scheme 61. Synthesis of hydroindoles 134.

The reaction of amidines 135 with various phenacyl, benzyl, or heteroalkyl halides in the presence of 1,8diazabicyclo[5.4.0]undec-7-ene (DBU) produced 2-aminopyrroles 136 and 137 in good to excellent yields (Scheme 62). ${ }^{94}$ 


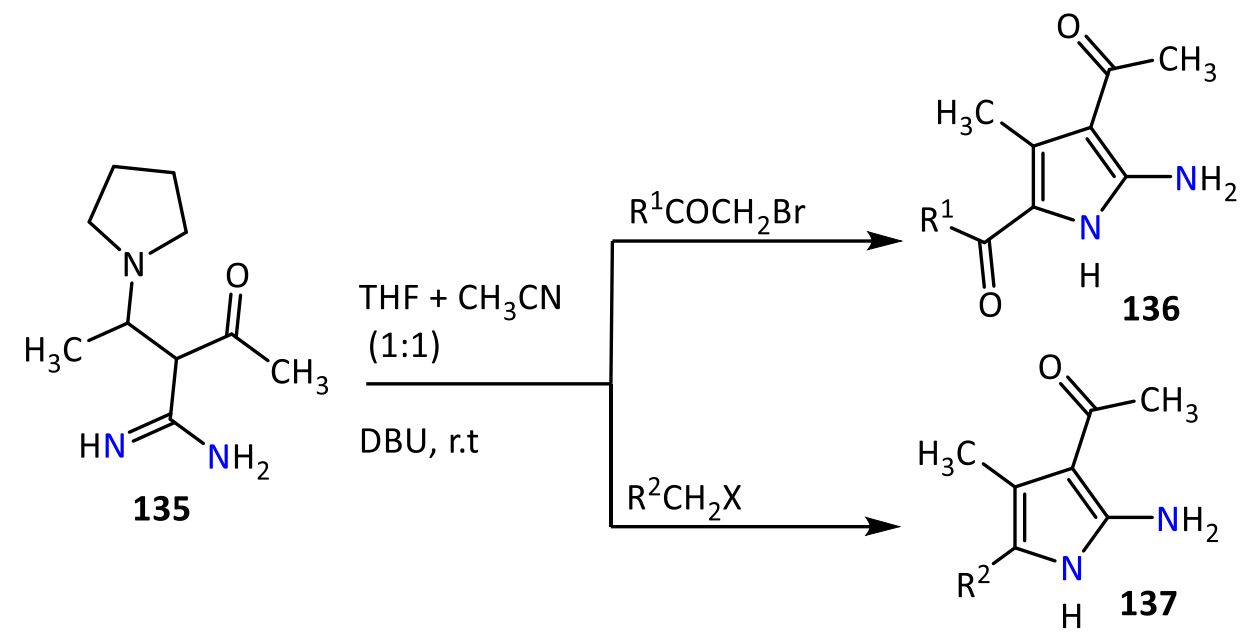

Scheme 62. Synthesis of pyrroles 136 and 137.

5.2.3.2. Thiazoles. An efficient one-pot method for the synthesis of 2-aminothiazoles 138 using isothiocyanates, amidines $\mathbf{7 Q}$ and various halomethylenes is reported. The synthesis of 2-aminothiazoles 138 involves reaction such as nucleophilic addition-alkylation and intramolecular nucleophilic substitution in which amines departs as the leaving group (Scheme 63). ${ }^{95}$

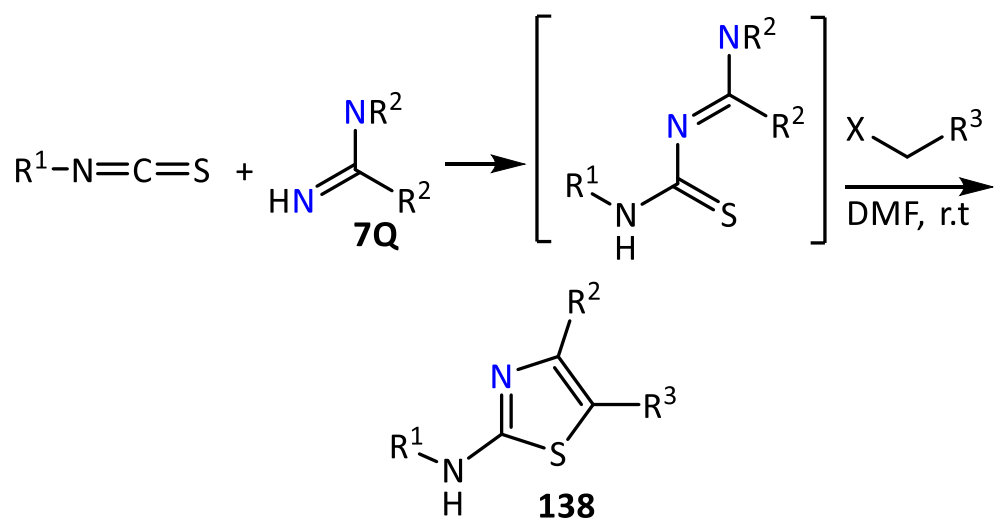

Scheme 63. Synthesis of thiazoles 138.

The preparation of 4,5-disubstituted 2-alkylaminothiazoles 140-143 involves the cyclocondensation of $N$ thioamidoamidines 139 with 2-haloalkyl derivatives in refluxing ethanol in the presence of one equiv. of pyridine (Scheme 64). ${ }^{96}$

5.2.3.3. Imidazoles. Treating amidines with 2-fluoronitrobenzenes led within 30 min under microwave irradiation to the formation of $\mathrm{N}$-(2-nitroaryl)-carboximidamides 144a-g (Scheme 65). ${ }^{97}$ Reduction of 144a-g using Pd-C gave an aminoamidine intermediate which cyclized to give imidazoles 145a-g (Scheme 65). ${ }^{97}$ 


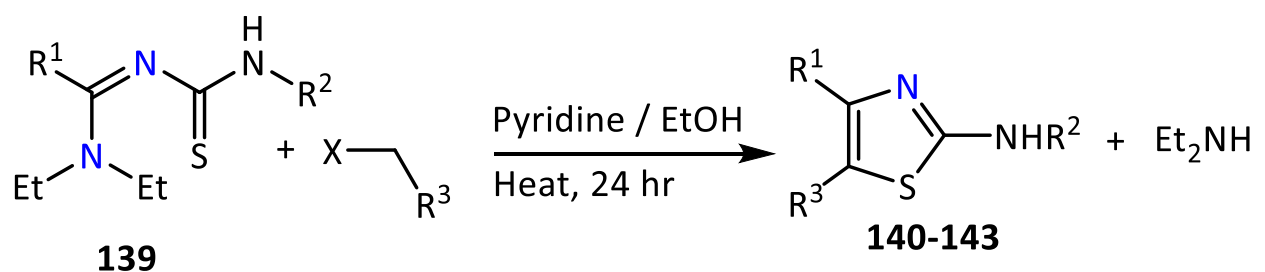

\begin{tabular}{|c|c|c|c|c|}
\hline & $x$ & $\mathrm{R}^{1}$ & $\mathrm{R}^{2}$ & $R^{3}$ \\
\hline $140 a$ & $\mathrm{Br}$ & $\mathrm{Ph}$ & $\mathrm{Ph}$ & $\mathrm{CO}_{2} \mathrm{Et}$ \\
\hline $140 \mathrm{~b}$ & $\mathrm{Br}$ & $\mathrm{Ph}$ & $\mathrm{Bn}$ & $\mathrm{CO}_{2} \mathrm{Et}$ \\
\hline $140 c$ & $\mathrm{Br}$ & $\mathrm{Ph}$ & $\mathrm{CH}_{3} \mathrm{CH}_{2}$ & $\mathrm{CO}_{2} \mathrm{Et}$ \\
\hline $140 d$ & $\mathrm{Br}$ & $\mathrm{CH}_{2}-\mathrm{Ph}$ & $\mathrm{Ph}$ & $\mathrm{CO}_{2} \mathrm{Et}$ \\
\hline $141 a$ & $\mathrm{Br}$ & $\mathrm{Ph}$ & $\mathrm{Ph}$ & $\mathrm{C}(\mathrm{O})-\mathrm{Ph}-\mathrm{p}-\mathrm{NO}_{2}$ \\
\hline $141 b$ & $\mathrm{Br}$ & $\mathrm{CH}_{2}-\mathrm{Ph}$ & $\mathrm{CH}_{2}-\mathrm{Ph}$ & $\mathrm{C}(\mathrm{O})-\mathrm{Ph}-\mathrm{p}-\mathrm{NO}_{2}$ \\
\hline $142 a$ & $\mathrm{Cl}$ & $\mathrm{Ph}$ & $\mathrm{Ph}$ & $\mathrm{CN}$ \\
\hline $142 b$ & $\mathrm{Cl}$ & $\mathrm{CH}_{2}-\mathrm{Ph}$ & $\mathrm{CH}_{2}-\mathrm{Ph}$ & $\mathrm{CN}$ \\
\hline $143 a$ & $\mathrm{Cl}$ & $\mathrm{Ph}$ & $\mathrm{Ph}$ & $\mathrm{C}(\mathrm{O})-\mathrm{CH}_{3}$ \\
\hline $143 b$ & $\mathrm{Cl}$ & $\mathrm{CH}_{2}-\mathrm{Ph}$ & $\mathrm{CH}_{2}-\mathrm{Ph}$ & $\mathrm{C}(\mathrm{O})-\mathrm{CH}_{3}$ \\
\hline
\end{tabular}

Scheme 64. Synthesis of thiazoles 140-143.<smiles>[R]C(=N)N</smiles>

1) $\mathrm{K}_{2} \mathrm{CO}_{3}$, DMSO, $110^{\circ} \mathrm{C}$, $\mathrm{MW}, 30 \mathrm{~min}$<smiles>[R]C(=N)Nc1cc([R2])c([R4])cc1[N+](=O)[O-]</smiles>

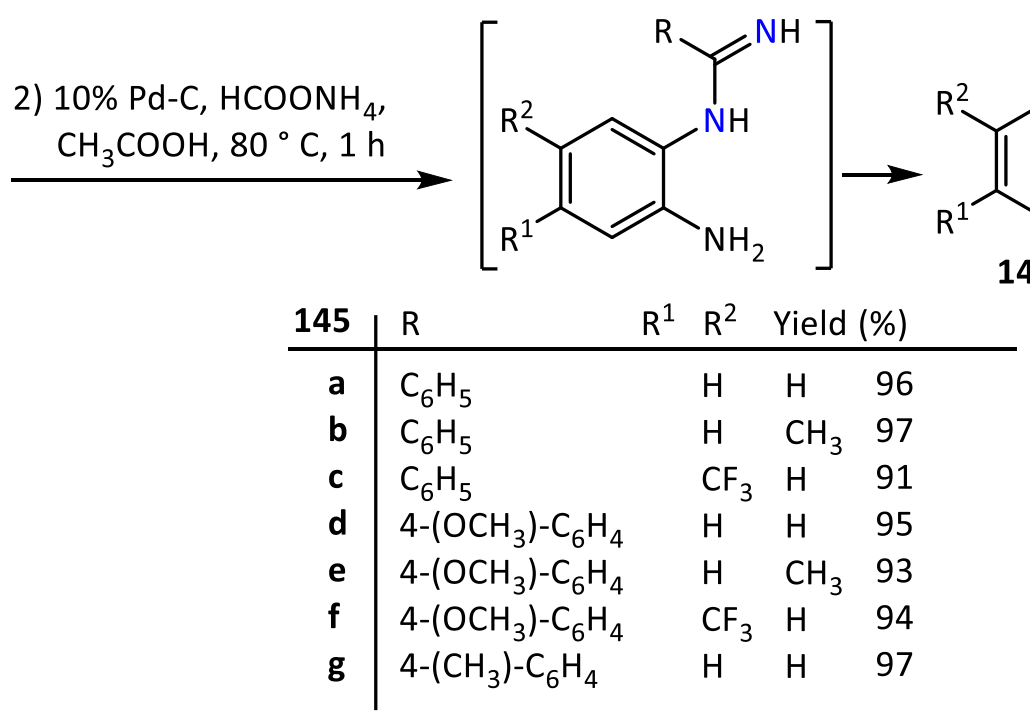

Scheme 65. Synthesis of fused imidazoles 145a-g. 
5-Amino-1-aryl-4-cyanoimidazoles 146a-d were prepared from the reaction functionalized amidines 27a-d in the presence of aqueous potassium hydroxide $(1 \mathrm{M})$ at room temperature (Scheme 66$).{ }^{98}$ One equivalent of cyanide is released during the reaction for the bisnitrile.

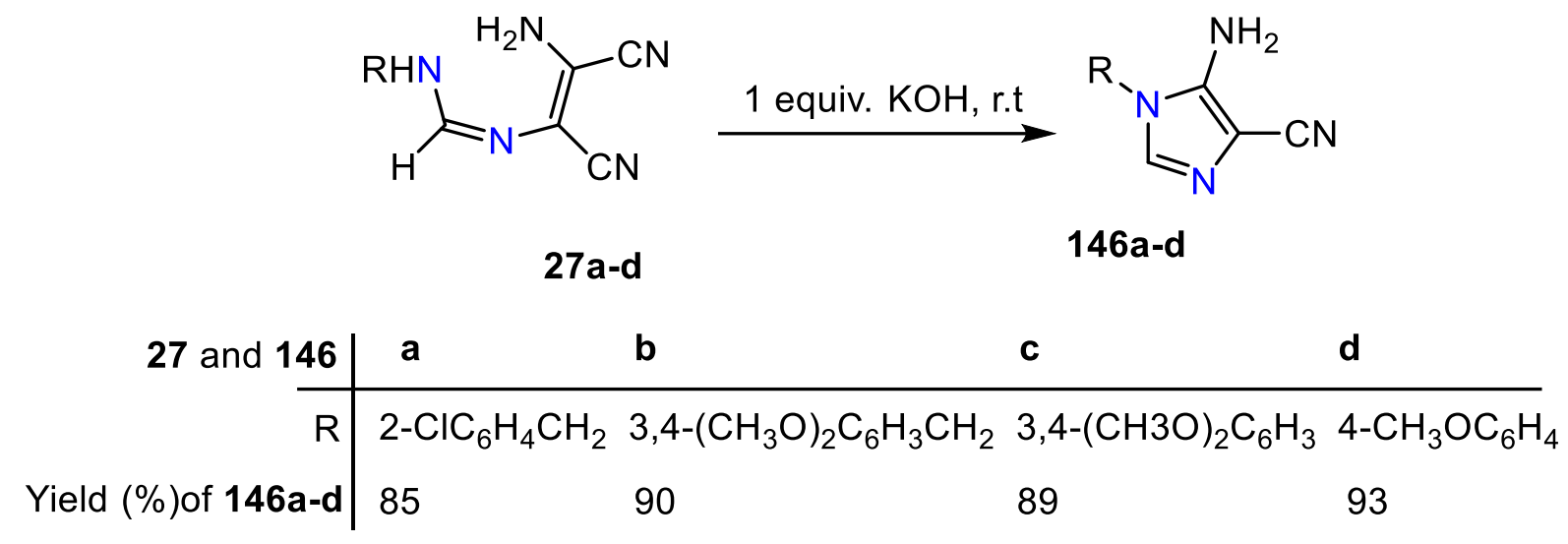

Scheme 66. Synthesis of imidazoles 146a-d.

Under the conditions shown in Scheme 67, benzaldehydes reacted with $N$-phenylbenzamidines 7R to provide the corresponding 1,2,4-trisubstituted imidazole derivatives 147 (Scheme 67). ${ }^{99}$

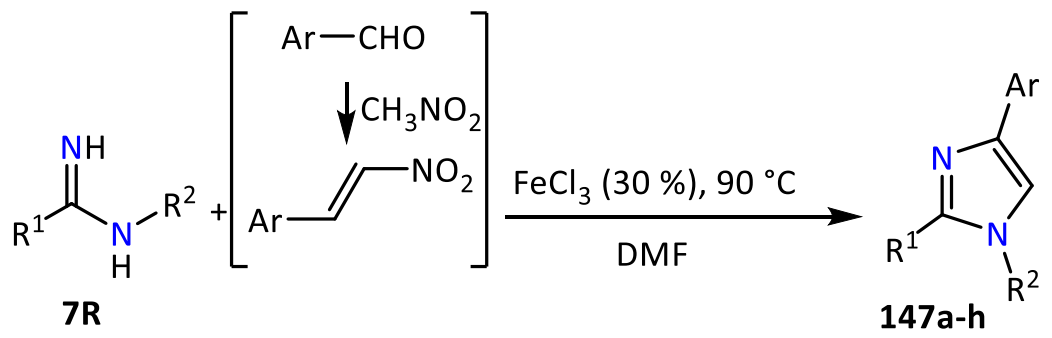

\begin{tabular}{r|ccclllll}
147 & \multicolumn{1}{c}{$\mathbf{a}$} & $\mathbf{b}$ & $\mathbf{c}$ & $\mathbf{d}$ & $\mathbf{e}$ & $\mathbf{f}$ & $\mathbf{g}$ & $\mathbf{h}$ \\
\hline $\mathrm{R}^{1}$ & $\mathrm{C}_{6} \mathrm{H}_{5}$ & $\mathrm{C}_{6} \mathrm{H}_{5}$ & $4-\mathrm{CH}_{3}-\mathrm{C}_{6} \mathrm{H}_{4}$ & $\mathrm{C}_{6} \mathrm{H}_{5}$ & $\mathrm{C}_{6} \mathrm{H}_{5}$ & $\mathrm{C}_{6} \mathrm{H}_{5}$ & $\mathrm{C}_{6} \mathrm{H}_{5}$ & $\mathrm{C}_{6} \mathrm{H}_{5}$ \\
$\mathrm{R}^{2}$ & $\mathrm{C}_{6} \mathrm{H}_{5}$ & $4-\mathrm{CH}_{3}-\mathrm{C}_{6} \mathrm{H}_{4} \mathrm{C}_{6} \mathrm{H}_{5}$ & $3-\mathrm{CH}_{3}-\mathrm{C}_{6} \mathrm{H}_{4}$ & $4-\mathrm{CH}_{3} \mathrm{OC}_{6} \mathrm{H}_{4}$ & $2-\mathrm{C}_{2} \mathrm{H}_{5} \mathrm{C}_{6} \mathrm{H}_{4}$ & $4-\mathrm{ClC}_{6} \mathrm{H}_{4}$ & $3-\mathrm{ClC}_{6} \mathrm{H}_{4}$ \\
Yield (\%) & 62 & 72 & 71 & 62 & 75 & 61 & 58 & 54
\end{tabular}

Scheme 67. Synthesis of imidazoles 147a-h.

Copper and palladium-catalyzed cycloamination reaction of 1,1-dibromoalkenes 148 with monofunctionalized amidines $\mathbf{7 S}$ in the presence of tetrabutylammonium fluoride solution (TBAF) to afford polysubstituted bromoimidazole derivatives 149 (Scheme 68). ${ }^{100}$ The bromo group from 149 was selectively replaced by a phenyl group under the conditions shown in Scheme 68 to give polysubstituted imidazoles 150 (Scheme 68). ${ }^{101}$ 


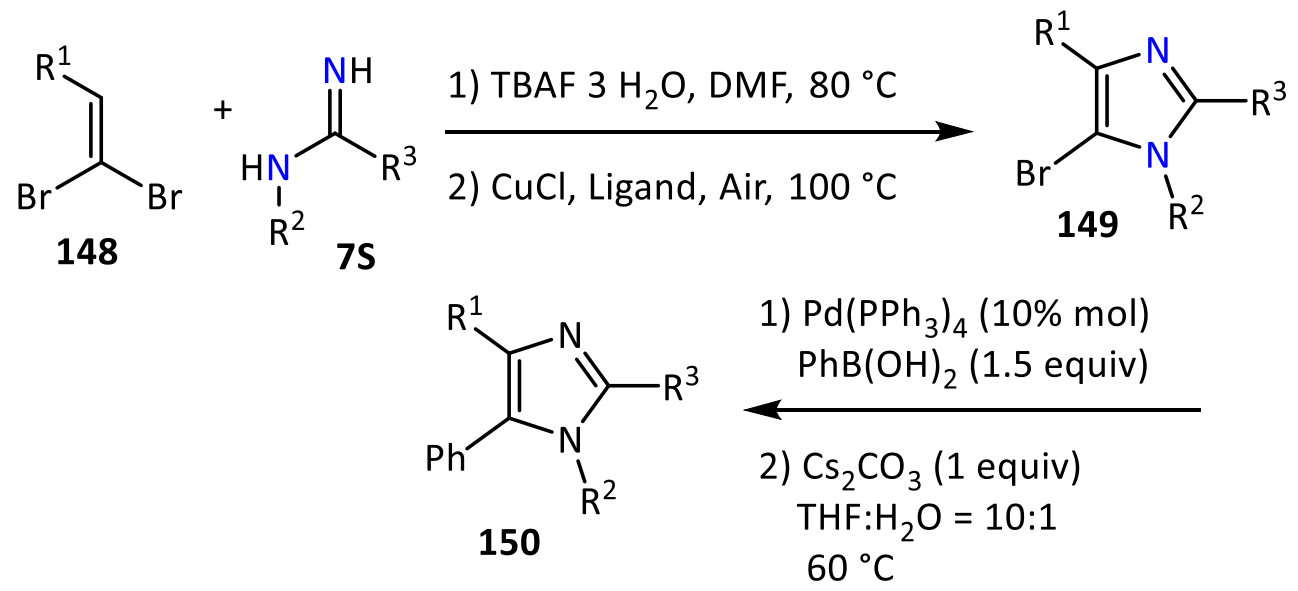

Scheme 68. Synthesis of imidazoles 150.

Benzimidazoles 151a-d can easily be prepared by the reaction of $\mathrm{N}$-arylamidines $7 \mathrm{~T}$ with $15 \% \mathrm{~mol}$ $\mathrm{Cu}\left(\mathrm{OAC}_{2}\right)$ in DMSO at $100{ }^{\circ} \mathrm{C}$ and under an oxygen atmosphere together with 5 equiv. of acetic acid (Scheme 69). ${ }^{102}$
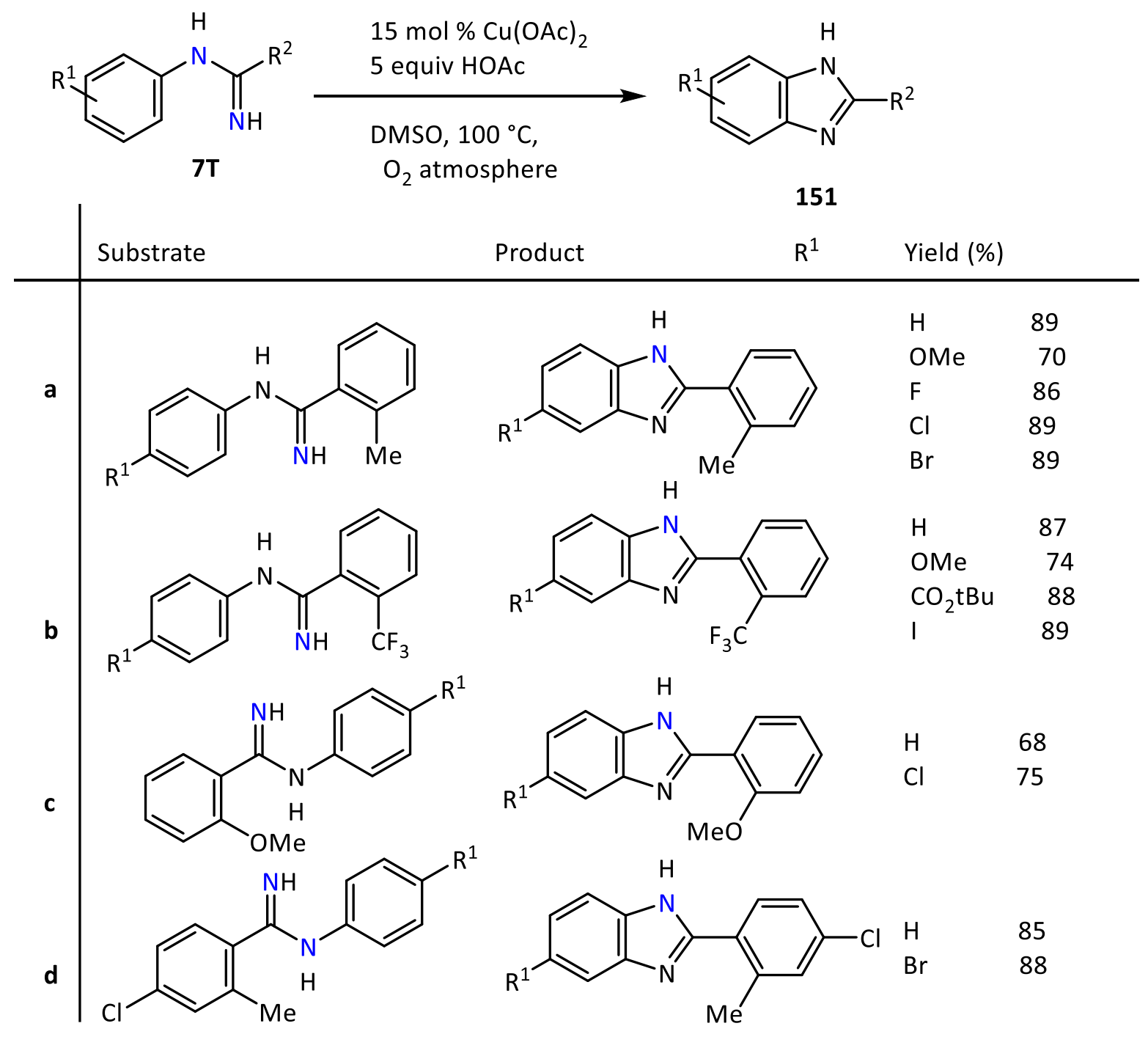

Scheme 69. Synthesis of fused imidazoles 151a-d. 
Starting with 2,3-dihydrothieno[3,4-b][1,4]dioxin (152), functionalized benzimidazoles 155 were prepared via oxidative coupling of thiophencarbaldehydes 153 or 154 with the appropriate 3,4-diaminobenzamidines in $60-70 \%$ yields (Scheme 70). ${ }^{103}$

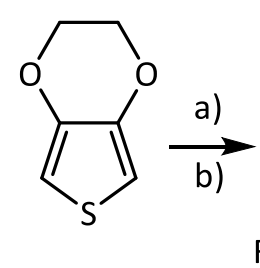

152<smiles>[R]c1ccc(-c2scc3c2OCCO3)cc1</smiles>

$153 \mathrm{R}^{1}=\mathrm{CN}, \mathrm{NO}_{2}$<smiles>[R]c1ccc(-c2sc(C=O)c3c2OCCO3)cc1</smiles>

$154 \mathrm{R}^{1}=\mathrm{CN}, \mathrm{NO}_{2}$

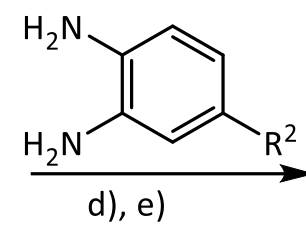

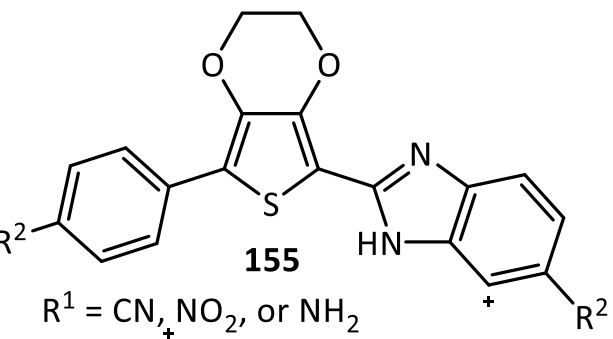<smiles></smiles>

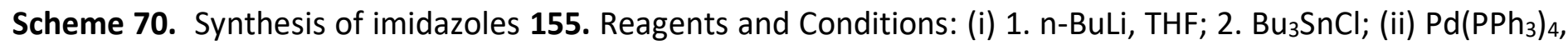
4-bromobenzonitrile or 1-bromo-4-nitrobenzene, THF; (iii) $\mathrm{POCl}_{3}$, DMF; (iv) 3,4-diaminobenzimidamide hydrochloride, 3,4-diamino- $N$-isopropylbenzimidamide hydrochloride, 4-(4,5-dihydro- $1 \mathrm{H}$-imidazol-2yl)benzene-1,2-diaminehydrochloride, 1,4-benzoquinone, $\mathrm{C}_{2} \mathrm{H}_{5} \mathrm{OH}$; v) $\mathrm{H}_{2}, 10 \% \mathrm{Pd} / \mathrm{C}, \mathrm{CH}_{3} \mathrm{OH}$.

Gold(I)-catalyzed synthesis of imidazole-5-carbaldehydes 157 from N-propargyl amidines 156 is as shown in Scheme 71. ${ }^{104}$<smiles>[R]C#CCNC([R])=Nc1ccccc1</smiles>

156

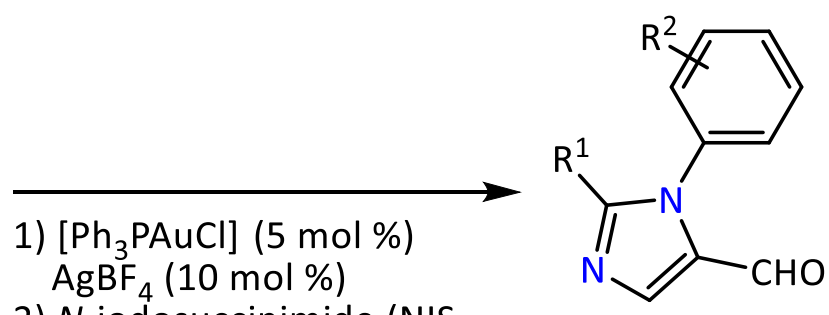

157

Scheme 71. Synthesis of imidazoles 157.

Five-membered condensed dihydroimidazolylbenzenesulfonamide derivatives 159a-i were obtained by the reaction of amidine derivatives $158 a-i^{105}$ with acylating agent oxalyl chloride (Scheme 72). ${ }^{106}$ 
<smiles>[R]C(=N)NNS(=O)c1ccc([R1])cc1</smiles>

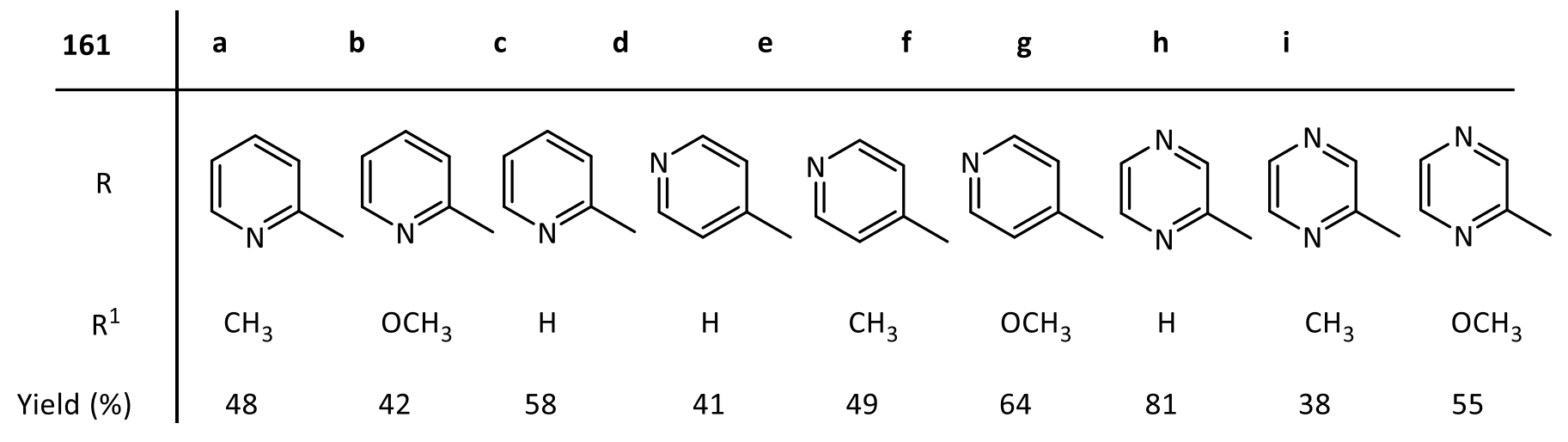

Scheme 72. Synthesis of imidazole-4,5-diones 159a-i.

It was found that the Cul-promoted cyclocondensation of $\mathbf{1 6 0}$ proceeded in refluxing acetonitrile in the presence of potassium carbonate and $10 \% \mathrm{~mol}$ of $N, N^{\prime}$-dimethylethylenediamine (DMEDA) as the base to give benzimidazoles 151 (Scheme 73). ${ }^{107}$

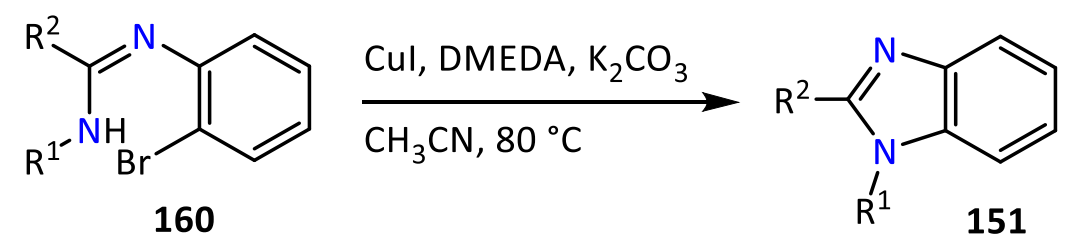

Scheme 73. Synthesis of benzimidazoles 151.

The formation of diarylimidazoles 147 was established by reacting $\alpha$-tosyloxyketones with amidines $7 \mathbf{U}$ in water as a solvent (Scheme 74). ${ }^{108}$

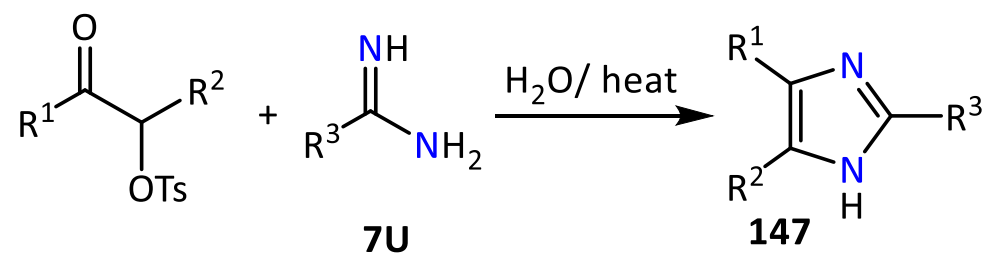

Scheme 74. Synthesis of imidazoles 147. 
It was reported on the synthesis of imidazole esters 164 from nitroallylic acetates 161 and amidine salts through a one-pot cascade intermolecular aza-SN2' reaction-intramolecular aza-Michael addition (Scheme 75). ${ }^{109}$ The reaction was described as due to addition of 161 to the positively nitrogen to form intermediate 162 (Scheme 74). Amidine-like addition accompanied by cylization process gave intermediate 163 (Scheme 74). Elimination of $\mathrm{HNO}_{2}$ from 163 produced 164 (Scheme 75). The same group used $\mathrm{CsCO}_{3}$ and at room temperature to synthesize imidazoles 165 via reaction (Z)-(2-bromo-2-nitrovinyl)benzene, as an example, with amidine chlorides in $\mathrm{CH}_{3} \mathrm{CN}$ (Scheme 75). ${ }^{110}$

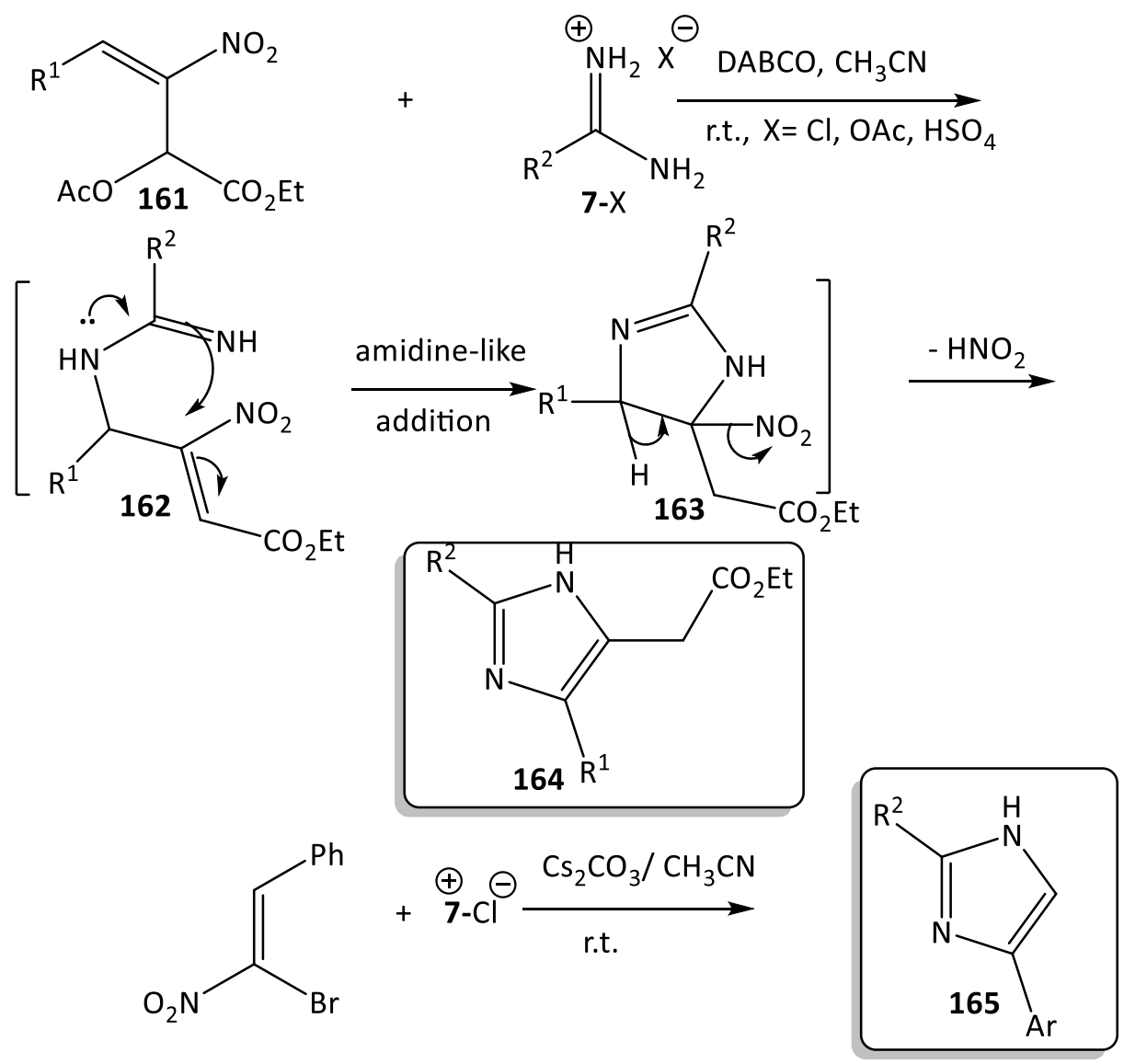

\section{Scheme 75}

5.2.3.4. Oxadiazoles. The reaction of 166 with 4 equivalents of hydroxylamine hydrochloride in methanol at room temperature led to complete consumption of 166 and gave 1,2,4-oxadiazoles 167 in 14-73\% yields (Scheme 76). ${ }^{111}$ 


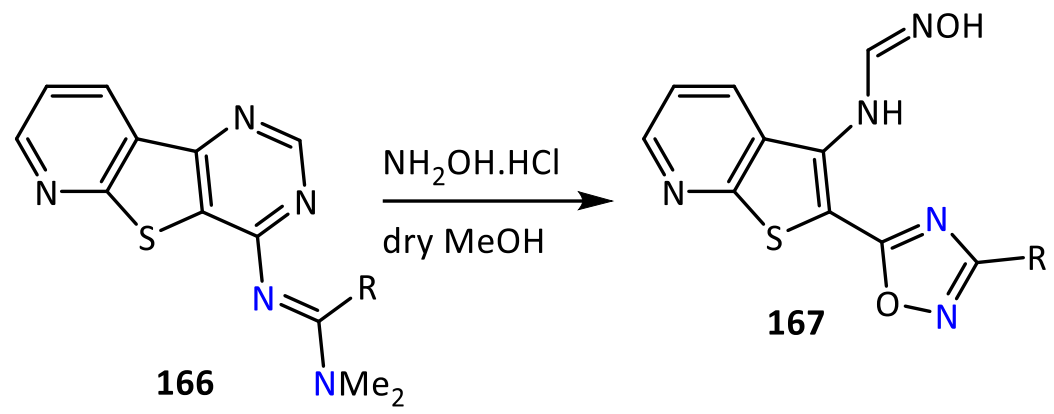

\begin{tabular}{|c|c|c|c|c|c|}
\hline 167 & $\mathrm{R}$ & Yield \% & 167 & $\mathrm{R}$ & Yield \% \\
\hline a & $\mathrm{Me}$ & 73 & f & 4- $\mathrm{MeOC}_{6} \mathrm{H}_{4}$ & Crude \\
\hline b & Et & 14 & g & $4-\mathrm{FC}_{6} \mathrm{H}_{4}$ & 46 \\
\hline C & $\mathrm{Ph}$ & 42 & h & $4-\mathrm{ClC}_{6} \mathrm{H}_{4}$ & 46 \\
\hline d & 4- $\mathrm{MeC}_{6} \mathrm{H}_{4}$ & 72 & I & $4-\mathrm{O}_{2} \mathrm{NC}_{6} \mathrm{H}_{4}$ & 55 \\
\hline e & $3,4-\mathrm{Me}_{2} \mathrm{C}_{6} \mathrm{H}_{3}$ & 60 & $\mathbf{j}$ & 3-pyridyl & 45 \\
\hline
\end{tabular}

Scheme 76. Synthesis of 1,2,4-oxadiazoles 167.

5.2.3.5. Thiadiazoles. A one-pot synthesis of 3 -substituted-5-amino-1,2,4-thiadiazoles 168 from amidine hydrochlorides $7 . \mathrm{HCl}$ and isothiocyanates was reported by Wu and Zhang (Scheme 77). ${ }^{112}$<smiles>[R]Nc1nc([R16]([R5])([H])[H])ns1</smiles>

Scheme 77. Synthesis of thiadiazoles 168 . Reaction conditions: isothiocyanate $(0.5 \mathrm{mmol}), 7 . \mathrm{HCl}(0.5 \mathrm{mmol})$, $\mathrm{Cs}_{2} \mathrm{CO}_{3}$ (3 equiv), $\left.\mathrm{Cu}(\mathrm{OTf})_{2}\right) 5 \% \mathrm{~mol}$ ), and solvent $(10 \mathrm{~mL})$ under air at $50{ }^{\circ} \mathrm{C}$.

$\mathrm{N}$-Thiocarbamoylamidine $\mathbf{1 6 9}$ is involved in N-S bond formation in the presence of (2,2,6,6-tetramethylpiperidin-1-yl)oxidanyl (TEMPO), which is known to be a good oxidizing agent, as shown in Scheme 78 to give 1,2,4-thiadiazole derivatives $168 .{ }^{113}$<smiles>N=C(NC(=S)Nc1ccccc1)c1ccccc1</smiles>

Scheme 78. Synthesis of thiadiazoles 168. 
5.2.3.6. Triazoles. Synthesis of 3,5-diaryl-1,2,4-triazoles $\mathbf{1 7 0}$ can be achieved from amidines $\mathbf{7 V}$ by a Cu(OTf) $2^{-}$ catalyzed reaction using $\mathrm{NaHCO}_{3}$ as a base, with 1,10-phenanthroline as an additive and $\mathrm{K}_{3}\left[\mathrm{Fe}(\mathrm{CN})_{6}\right]$ under atmospheric oxygen (Scheme 79). ${ }^{114-116}$
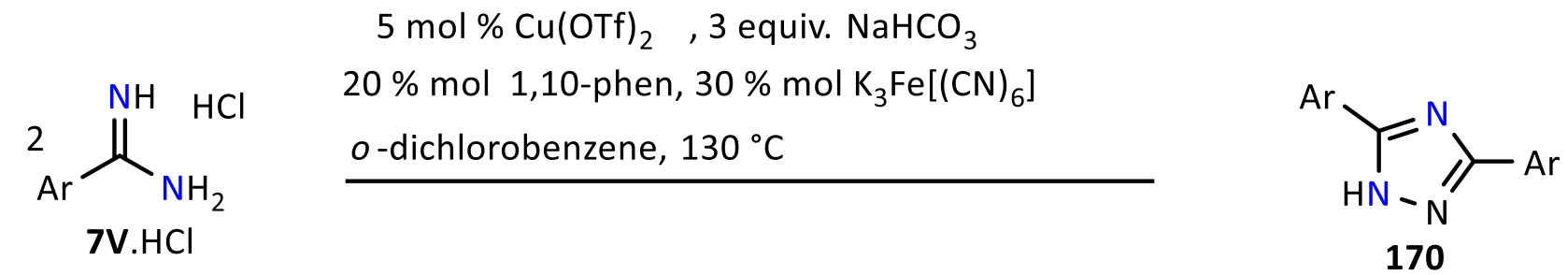

Scheme 79. Synthesis of triazoles 170.

5.2.4. Synthesis of six-membered rings. 5.2.4.1. Pyridines. N-Arylamidine 171 was converted into the 6aminophenanthridine $\mathbf{1 7 2}$ in excellent yield through a Pd-catalyzed intramolecular coupling reaction (Scheme 80). ${ }^{117}$

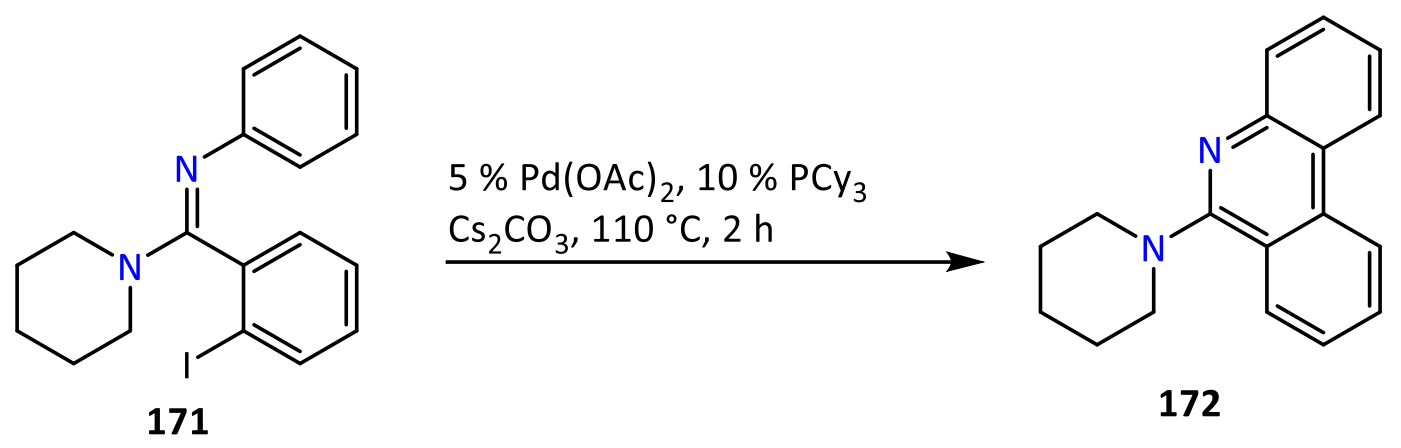

Scheme 80. Synthesis of phenanthridine 172.

Addition of $\mathrm{N}$-phenyl-2-chlorobenzamidine (173) to a sodium amide suspension in liquid ammonia led to the formation of 6-aminophenanthridine (172) (Scheme 81). ${ }^{118}$<smiles>N=C(Nc1ccccc1)c1ccccc1Cl</smiles>

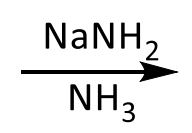

173

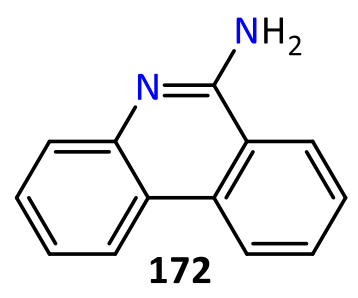

172

Scheme 81. Synthesis of 6-aminophenanthridine.

Gomaa and Döpp et al. prepared 1,4-dihydropyridines 176 from the reaction of $N^{1}, N^{2}$-diarylamidines $7 \mathbf{W}$ and (2,3-diphenylcyclopropen-1-ylidene)propanedinitrile (175, Scheme 82). ${ }^{119}$ 


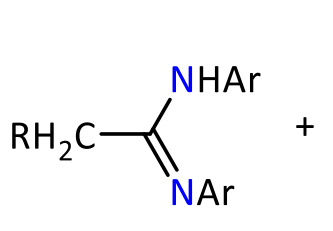

$7 w$

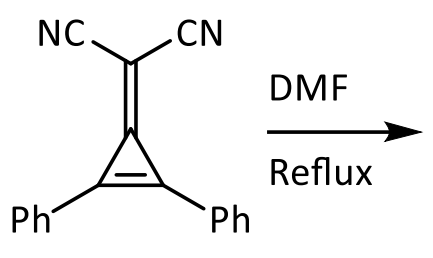

175<smiles>[R]C1=C(N[Ga])N([Ga])C(c2ccccc2)=C(c2ccccc2)C1=C(C#N)C#N</smiles>

176

Scheme 82. Reaction of acetamidines with (2,3-diphenylcyclopropen-1-ylidene)propanedinitrile (175).

5.2.4.2. Pyrimidines. A simple and direct synthesis of polysubstituted 5 -aminopyrimidines 178 from $\alpha$ azidovinyl ketones $\mathbf{1 7 7}$ and amidines 7X in the presence of base was developed. The reaction was performed in anhydrous DMF with 1.2 equivalent of amidines and 2.4 equivalent of $\mathrm{K}_{2} \mathrm{CO}_{3}$ under $\mathrm{N}_{2}$ atmosphere and at room temperature (Scheme 83$).{ }^{120}$<smiles>[R]C=C(N)C([R1])=O</smiles>

177

I<smiles>[R]C(=N)N</smiles>

7X

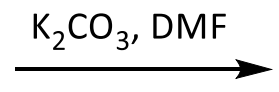

r.t<smiles>[Y8]c1nc([R])c(N)c([R])n1</smiles>

$178 \mathrm{NH}_{2}$

\begin{tabular}{c|cccc}
178 & $\mathrm{R}^{1}$ & $\mathrm{R}^{2}$ & $\mathrm{R}^{3}$ & Yield \% \\
\hline a & $\mathrm{Ph}-$ & $4-\mathrm{BrC}_{6} \mathrm{H}_{4} 4^{-}$ & $\mathrm{H}$ & 95 \\
b & $4-\mathrm{MeC}_{6} \mathrm{H}_{4}$ & $4-\mathrm{BrC}_{6} \mathrm{H}_{4}-$ & $\mathrm{CH}_{3}$ & 81 \\
c & $4-\mathrm{ClC}_{6} \mathrm{H}_{4}$ & $4-\mathrm{BrC}_{6} \mathrm{H}_{4}$ & $\mathrm{Ph}$ & 81 \\
d & $4-\mathrm{O}_{2} \mathrm{NC}_{6} \mathrm{H}_{4}$ & $4-\mathrm{MeOC}_{6} \mathrm{H}_{4-}$ & $\mathrm{CH}_{3}$ & 77 \\
e & $4-\mathrm{MeOC}_{6} \mathrm{H}_{4}$ & $2-\mathrm{BrC}_{6} \mathrm{H}_{4}$ & $\mathrm{H}$ & 70 \\
f & 2-thienyl & $4-\mathrm{FC}_{6} \mathrm{H}_{4-}^{-}$ & $\mathrm{CH}_{3}$ & 82
\end{tabular}

Scheme 83. Synthesis of 5-aminopyrimidines 178.

When $N$-[imino(phenyl)methyl]-2-nitrobenzamides 179 reacted with amidines $7 Y$ with 2-nitrobenzoic acid derivatives, various 181a-o were obtained by the sequences shown in Scheme $84 .{ }^{98}$ It is important to show that the hydroxybenzotriazole ( $\mathrm{HOBt}$ ) was used as a catalyst to suppress peptide linkage. In addition to $N, N^{\prime}$ dicyclohexylcarbodiimide (DDC) was also used in the former reaction to couple amino acids during artificial peptide synthesis.

Magnesium oxide ( $\mathrm{MgO}$ ) effectively catalyzed the three-component reaction of aldehydes, amidine salts $7 Y . \mathrm{HCl}$, and malononitrile or ethyl cyanoacetate to form 4-amino-5-pyrimidine-carbonitriles 182 and pyrimidinone derivatives $\mathbf{1 8 3}$, respectively (Scheme 85 ). ${ }^{121}$ 


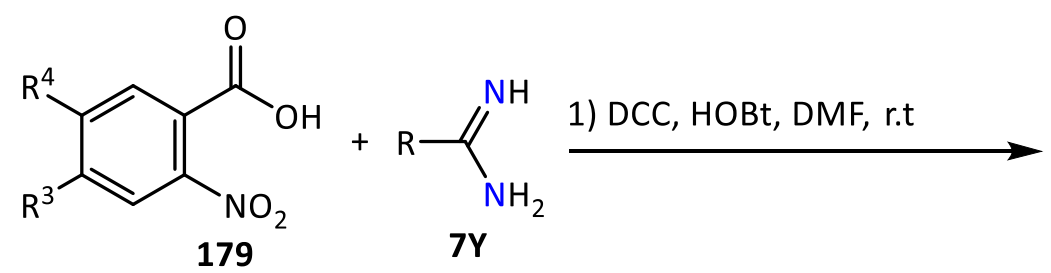<smiles>[R]C(=N)NC(=O)c1cc([Z8])c([R9])cc1[N+](=O)[O-]</smiles>

\begin{tabular}{|c|c|c|c|c|c|c|c|c|c|}
\hline 181 & $\mathrm{R}$ & $\mathrm{R}^{3}$ & $\mathrm{R}^{4}$ & $\begin{array}{c}\text { Yield } \\
\% \\
\end{array}$ & 181 & $\mathrm{R}$ & $\mathrm{R}^{3}$ & $\mathrm{R}^{4}$ & $\begin{array}{c}\text { Yield } \\
\%\end{array}$ \\
\hline$a$ & $\mathrm{Ph}$ & $\mathrm{H}$ & $\mathrm{H}$ & 96 & $\mathbf{i}$ & $4-\mathrm{MeC}_{6} \mathrm{H}_{4}$ & OMe & $\mathrm{H}$ & 93 \\
\hline b & $\mathrm{Ph}$ & $\mathrm{H}$ & $\mathrm{Me}$ & 91 & $\mathbf{k}$ & 3- $\mathrm{MeC}_{6} \mathrm{H}_{4}$ & $\mathrm{H}$ & $\mathrm{H}$ & 94 \\
\hline c & $\mathrm{Ph}$ & OMe & $\mathrm{H}$ & 95 & I & $3-\mathrm{MeC}_{6} \mathrm{H}_{4}$ & $\mathrm{H}$ & Me & 91 \\
\hline d & $4-\mathrm{MeOC}_{6} \mathrm{H}_{4}$ & $\mathrm{H}$ & $\mathrm{H}$ & 97 & m & 3- $\mathrm{MeC}_{6} \mathrm{H}_{4}$ & OMe & $\mathrm{H}$ & 94 \\
\hline e & $4-\mathrm{MeOC}_{6} \mathrm{H}_{4}$ & $\mathrm{H}$ & $\mathrm{Me}$ & 92 & $\mathbf{n}$ & $\mathrm{CH}_{3}$ & $\mathrm{H}$ & $\mathrm{H}$ & 93 \\
\hline$f$ & $4-\mathrm{MeOC}_{6} \mathrm{H}_{4}$ & OMe & $\mathrm{H}$ & 96 & $\mathbf{0}$ & $\mathrm{CH}_{3}$ & $\mathrm{H}$ & $\mathrm{Me}$ & 95 \\
\hline $\mathbf{g}$ & 4- $\mathrm{MeC}_{6} \mathrm{H}_{4}$ & $\mathrm{H}$ & $\mathrm{H}$ & 91 & p & $\mathrm{CH}_{3}$ & OMe & $\mathrm{H}$ & 96 \\
\hline $\mathbf{h}$ & 4- $\mathrm{MeC}_{6} \mathrm{H}_{4}$ & $\mathrm{H}$ & $\mathrm{Me}$ & 95 & & & & & \\
\hline
\end{tabular}

Scheme 84. Synthesis of fused pyrimidines 181a-p.

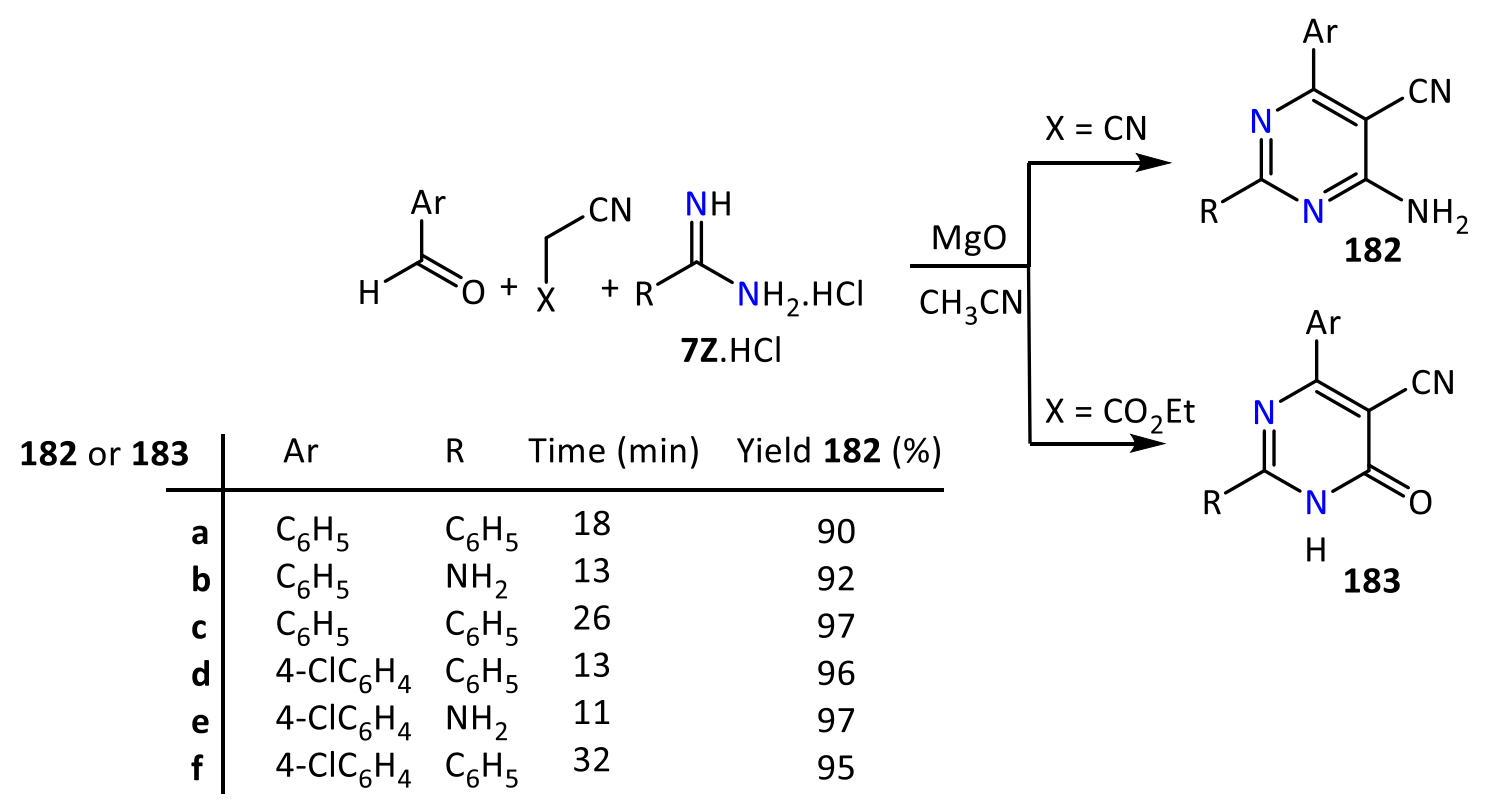

Scheme 85. Synthesis of pyrimidines 182 and 183.

Aly et al. ${ }^{122}$ demonstrated that 2,3-diphenylcyclopropenone (184) reacted with substituted thiocarbamoylamidines 185 to form the pyrimidin-4(3H)-ones 186 (Scheme 86). ${ }^{122}$ 
<smiles></smiles><smiles>O=c1c(-c2ccccc2)c(-c2ccccc2)nc(-c2ccccc2)n1[GaH2]</smiles>

Scheme 86. Synthesis of pyrimidinones 186.

The synthesis of 2,4-substituted 5-azolythiopyrimidines 190 was achieved by sequential Michael-addition of 3-iodochromone (187) with 1-methyl-1H-imidazole-2-thiol (188) and then condensation with amidine 7a (Scheme 87). ${ }^{123}$ It was believed that the reaction pathway involved the formation of intermediate 189 as shown in Scheme 87.

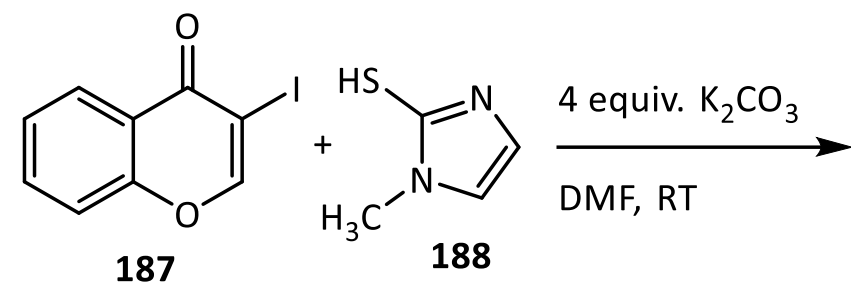

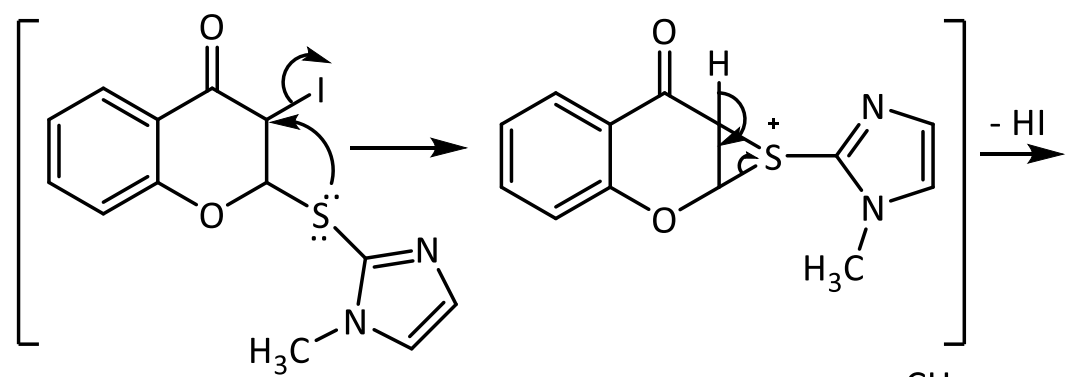<smiles>CC(=N)N</smiles>

Scheme 87. Synthesis of pyrimidines 190.

It was previously known that the reaction of 2-amino- $N^{1}$-(2-aminoaryl)benzamidines 191a with 4,5 dichloro-1,2,3-dithiazolium chloride 192 (Appel salt) produce 3-aryl-4-imino-3,4-dihydroquinazoline-2carbonitriles 193. ${ }^{124}$ Szczepankiewicz et al. ${ }^{125,126}$ developed a solvent free synthesis of 3-arylquinazolin-4(3H)imines 194 from 191a and triethyl orthoformate (Scheme 88). 


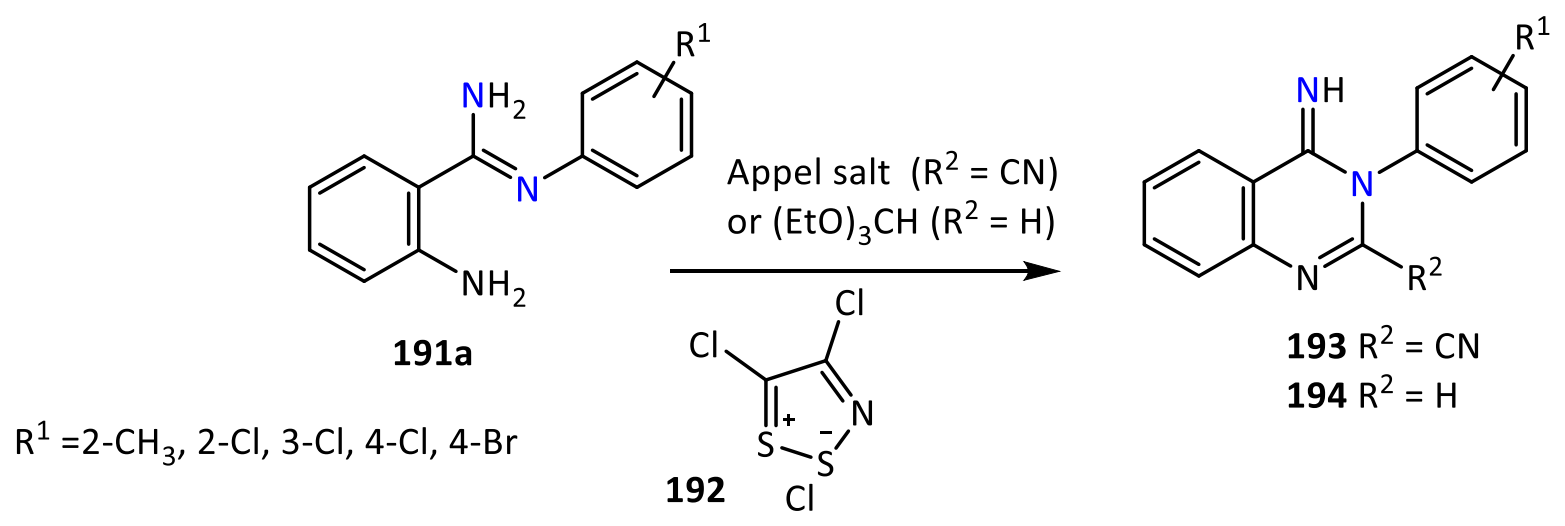

Scheme 88. Synthesis of fused pyrimidines 193 and 194 with the aid of Appel salts.

The synthesis of 4-aminoquinazolines 196 was made possible by palladium-catalyzed intramolecular imidoylation of $\mathrm{N}$-(2-bromoaryl)amidines 191b with tert-butylisocyanide (195) in the presence of KOAc and DMF mixture (Scheme 89). ${ }^{127,128}$<smiles>CC(C)(C)Nc1nc(-c2ccccc2)nc2ccc([N+](=O)[O-])cc12</smiles>

Scheme 89. Synthesis of 4-aminoquinazolines 196.

Aly et al. have recently reported that amidines 7AA react with malononitrile dimer 197 in DMF catalyzed with a few drops of piperidine to give hydropyrimidines 198 in $70-89 \%$ yield (Scheme 90). ${ }^{129}$<smiles>[R]N=C(Nc1ccccc1)c1ccccc1</smiles>

7AA

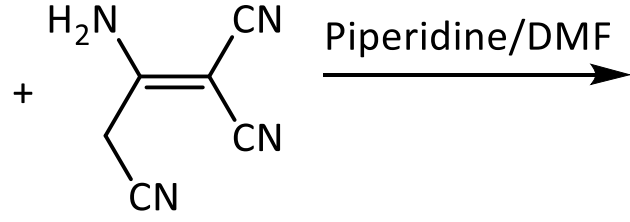

197<smiles>[R]N1C(N)=CC(=C(C#N)C#N)NC1(N)c1ccccc1</smiles>

198

Scheme 90. Synthesis of pyrimidines 198.

5.2.4.3. Thiadiazines. It has been shown that treatment of $[1,2-a]$ benzimidazol-2-yl as iminoesters derivatives 199 with $\mathrm{NaSCN}$ in dioxane $/ \mathrm{H}_{2} \mathrm{O}$ under reflux gave only the fused thiadiazine products 200 (Scheme 91). ${ }^{130}$ 


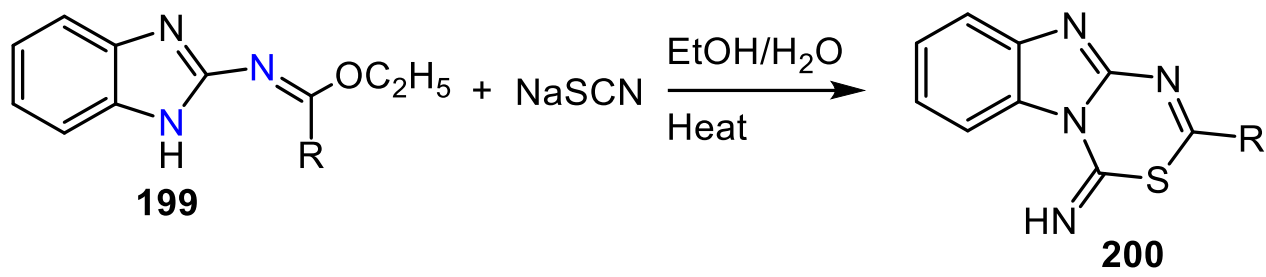

$\mathbf{a}, \mathrm{R}=\mathrm{Me} ; \mathbf{b}, \mathrm{R}=\mathrm{Et}$

Scheme 91. Synthesis of fused imidazothiadiazines 200.

Aly and co-workers reported the reaction of thiamidoamidines 185 with 1,1,2,2-tetracyanoethylene (201) affording thiadiazines 202 in 85-68\% yields (Scheme 92). ${ }^{131}$<smiles>N#CC(C#N)=C(C#N)C#N</smiles>

201<smiles>N/C(=N/[Ga])c1ccccc1</smiles>

$\mathrm{H}$<smiles>NC(=S)Nc1ccccc1</smiles>

185 anhy. EtOH

r.t, $2-6 \mathrm{~h}$<smiles>N#CC1(C#N)S/C(=N\c2ccccc2)N=C(c2ccccc2)N1[Ga]</smiles>

202

Scheme 92. Synthesis of thiadiazines 202.

5.2.4.4. Triazines. A reaction sequence furnishing triazines 203 starts with 3,4,5-trimethylphenyl isothiocyanate which was added to the sodium salt of cyanamide in DMF. In turn, benzamidine hydrochloride 7. $\mathrm{HCl}$ reacts smoothly with this intermediate at room temperature in the presence of triethylamine and EDC to yield 1,3,5-triazine-2,4-diamines 203 in good yields (Scheme 93). ${ }^{132}$
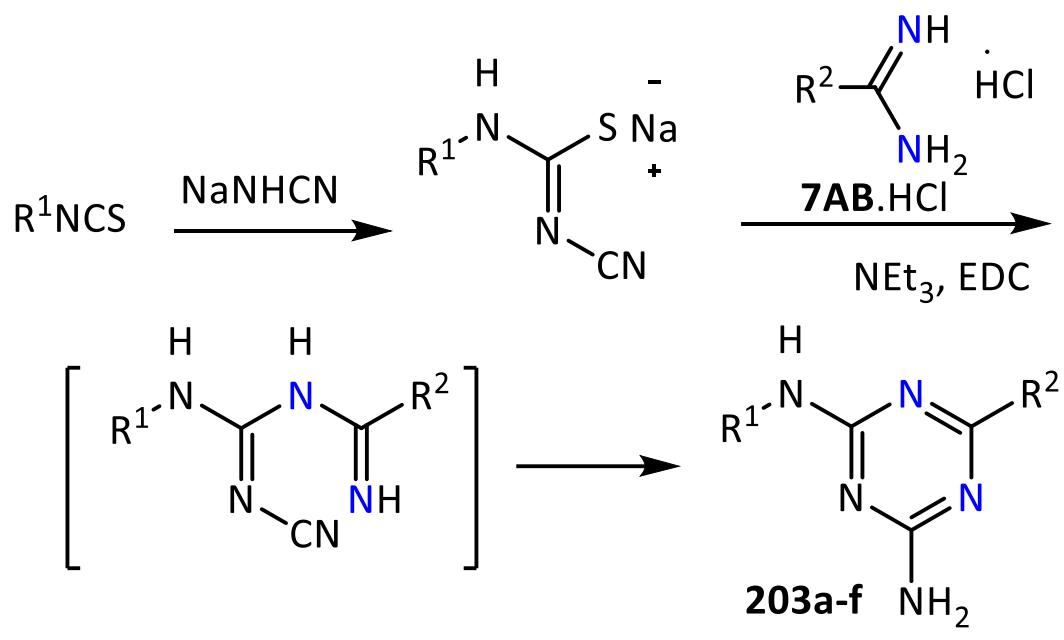

\begin{tabular}{c|cccc|cccc} 
203 & $\mathrm{R}^{1}$ & $\mathrm{R}^{2}$ & Yield \% & & $\mathbf{2 0 3}$ & $\mathrm{R}^{1}$ & $\mathrm{R}^{2}$ & Yield \% \\
\cline { 1 - 3 } a & $3,4,5-\mathrm{Me}_{3} \mathrm{C}_{6} \mathrm{H}_{2}$ & $\mathrm{Ph}$ & 71 & & $\mathbf{d}$ & $\mathrm{Ph}$ & $4-\mathrm{H}_{2} \mathrm{NCOC}_{6} \mathrm{H}_{4}$ & 65 \\
b & $2,4-\mathrm{Cl}_{2} \mathrm{C}_{6} \mathrm{H}_{3}$ & $\mathrm{Ph}$ & 54 & & e & $\mathrm{Ph}$ & $\mathrm{Ph}$ & 72 \\
c & cyclohexyl & $\mathrm{Ph}$ & 50 & & $\mathbf{f}$ & $\mathrm{PhCH}_{2}$ & $\mathrm{Ph}$ & 44
\end{tabular}

Scheme 93. Synthesis of triazines 203a-f. 
Benzamidine (7b) reacted with (4-chlorophenyl)isothiocyanate in DMF at $80{ }^{\circ} \mathrm{C}$ using $\mathrm{NaOH}$ as a base under microwave heating to provide polysubstituted 1,3,5-triazines 204 in moderate yields (Scheme 94). ${ }^{133}$<smiles>[Al]PI</smiles>

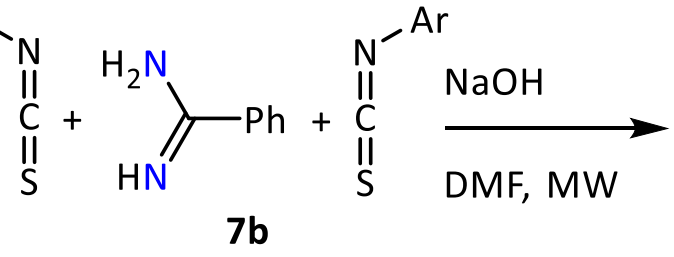

Ar $=4$-chlorophenyl<smiles>[Al]NC(=S)N[Ga]</smiles>

204

Scheme 94. Synthesis of triazines 204.

It has been reported that amidines, isoureas, isothioureas and guanidines react with aroyl isothiocyanates to give 1,3,5-triazine thione derivatives 204 (Scheme 95). ${ }^{134-136}$<smiles>[X]C(=N)[CH+]C(=O)OCC(C)O</smiles>

204

Scheme 95. Synthesis of 1,3,5-triazines 204.

5.2.4.5. Tetrazines. The reaction of $C$-aroyl- $N$-arylnitrilimines 205 with 1,1 -dimethylhydrazine or 1-methyl-1phenylhydrazine led to the formation of the acyclic electrophilic addition products, which underwent thermal oxidative cyclization at $\mathrm{CH}_{3}$ to 1,2,3,4-tetrahydro-s-tetrazines 206 as shown in Scheme 96. 137,138

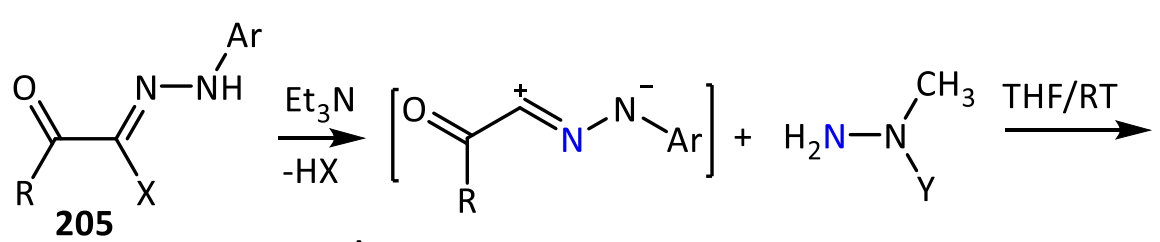
205<smiles>[R]C(=O)/C(=N/N[Al])N([TlH])N([Y])C</smiles>
$\mathrm{X}=\mathrm{Cl}$ or $\mathrm{Br}$ $\mathrm{Ar}=4-\mathrm{ClC}_{6} \mathrm{H}_{4}$
$\mathrm{Pd} / \mathrm{C}$ or $\mathrm{LiH}$ $\stackrel{\text { Heat, } 2-4 \mathrm{hr}}{\longrightarrow}$<smiles>[R]C(=O)C1=NN([Al])CN([Y])N1</smiles>

206a-i

R/Y: a, Me/Me; b, Me/Ph; c, Ph/Ph; e, PhNH/Me; f, PhNH/Ph; g, 2-Furyl/Me; h, 2-Furyl/Ph; i, 2Thienyl/Me; j, 2-Thienyl/Ph; k, 2-Naphthyl/Me; I, 2-Naphthyl/Ph

Scheme 96. Synthesis of 1,2,4,5-tetrazines 206a-i. 
5.2.4.6. Thiatriazines. Reaction of primary aliphatic amines with benzimidazole 199 in the presence of two equivalent of thionyl chloride pyridine under reflux yielded $[1,2,4,6]$ thiatriazino[2,3-a][1,3]benzimidazol$1(2 H)$-one 207 in good yields (Scheme 97). ${ }^{139}$

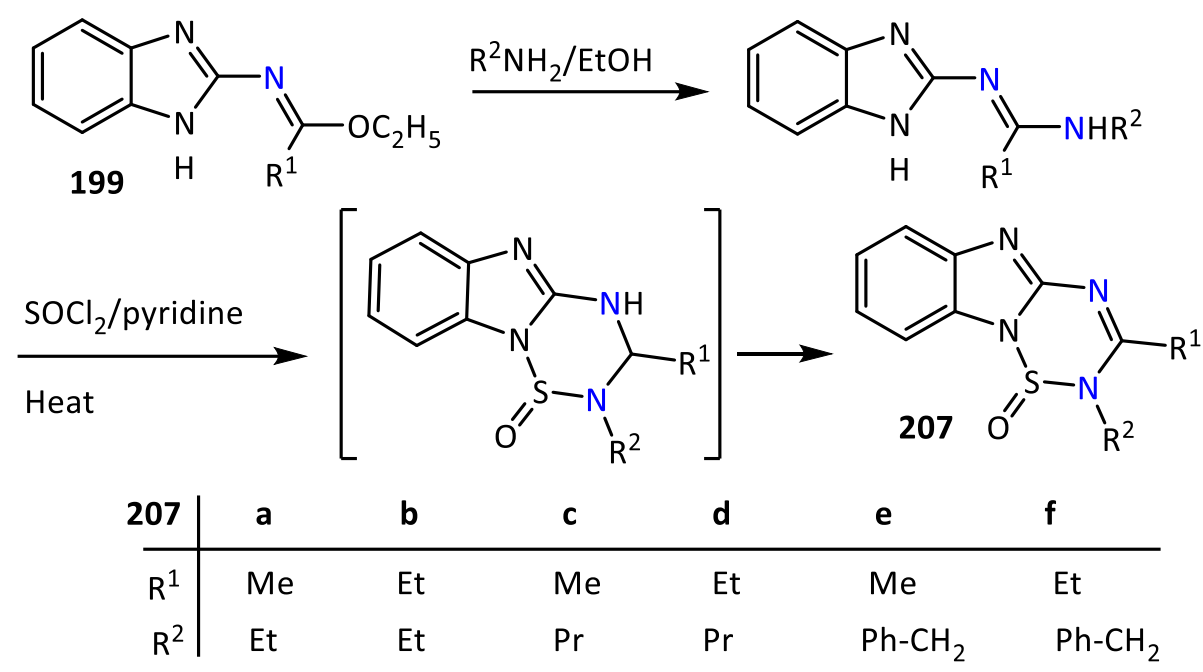

Scheme 97. Synthesis of imidazothiatriazines 207.

5.2.5. Synthesis of seven-membered rings. 5.2.5.1. Thiadiazepines. In a different manner, the reactions between 185 and 128 in acetic acid at reflux temperature afforded the 1,3,5-thiadiazepines 209 in 65-84\% yield (Scheme 98). ${ }^{140}$

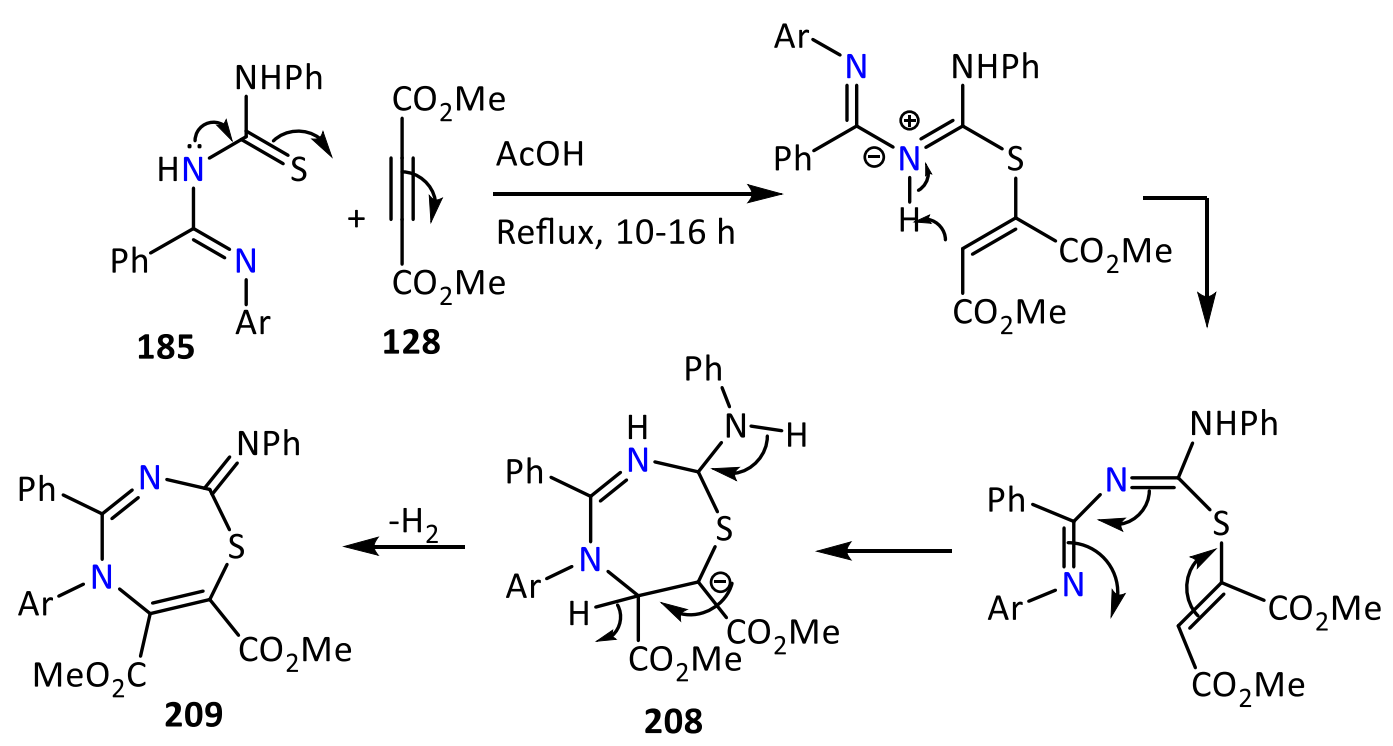

Scheme 98. Synthesis of 1,3,5-thiadiazepines 209.

The reaction mechanism was explained by a conjugate addition of thione lone pair to the acetylenic bond followed by hydrogen transfer and cyclization to form salt 208). Finally, elimination of hydrogen molecule from 208 would form 209. ${ }^{140}$ 


\section{Abbreviations}

TEA - triethylamine; Bt - benzotriazolyl; HOBt - 1-hydroxybenzotriazole; MW - microwave; EDC - 1-ethyl-3(3-dimethylaminopropyl)carbodiimide; NCS - N-chlorosuccinimide; SFRC* - solvent free reaction conditions; NaHMDS - sodium hexamethyldisilazide; phen - phenanthroline; TEMPO - tetramethylpiperidinyl $\mathrm{N}$-oxide

\section{Acknowledgements}

We appreciate funding and support from the Deutsche Forschungsgemeinschaft (DFG) for Prof Ashraf A. Aly

\section{References}

1. The Chemistry of Carboxylic Acids and Esters Patai, S., Ed. Interscience: London, 1969.

2. The Chemistry of the Carbon-Nitrogen Double Bond Patai, S., Ed. Interscience: London, 1970.

3. The Chemistry of Amides Zabicky, J., Ed. Interscience: London, 1972.

4. Raczynska, E. D. Polish J. Chem. 1993, 67, 1145-1153.

5. Baidya, M.; Mayr, H. Chem. Commun. 2008, 1792-1794.

https://doi.org/10.1039/b801811a

6. Hantzsch, A. Ber. 1930, 63, 1782-1788.

https://doi.org/10.1002/cber.19300630725

7. Runer, M. E.; Kilpatric, M. L.; Wagner, E. C. J. Am. Chem. Soc. 1947, 69, 1406-1412. https://doi.org/10.1021/ia01198a049

8. Neumann, R. C.; Jr.; Hammond, G. S. J. Phys. Chem. 1963, 67, 1659-1662.

9. Nakamura, S.; Umezawa, H. Chem. Pharm. Bull. 1966, 14, 981-986.

https://doi.org/10.1248/cpb.14.981

10. Schipper, D. J. Antibiotics 1983, 36, 1076-1077.

https://doi.org/10.7164/antibiotics.36.1076

11. Kaneda, M. J. Antibiotics 2002, 55, 924-928. https://doi.org/10.7164/antibiotics.55.924

12. Nakamura, H.; Koyama, G.; litaka, Y. J. Am. Chem. Soc. 1974, 96, 4327-4328. https://doi.org/10.1021/ja00820a049

13. Ohno, M.; Yagisawa, N.; Shibahara, S. J. Am. Chem. Soc. 1974, 96, 4326-4327. https://doi.org/10.1021/ja00820a048

14. Boyd, G. V. In The Chemistry of Amidines and Imidates, Vol. 2; Patai, S., Rappoport, Z., Eds.; John Wiley \& Sons: New York, 1991: p367.

15. Wang, J.; Xu, F.; Shen, Q. Org. Lett., 2008, 10, 445-448.

https://doi.org/10.1021/ol702739c

16. Dunn, P.J.; Dunne, C. U.S. Patent 0013464. 2002, 136, 69817.

17. Garigipati, R. S. Tetrahedron Lett. 1990, 31, 1969-1972. https://doi.org/10.1016/S0040-4039(00)88891-7

18. Rousselet, G.; Capdevielle, P.; Maumy, M. Tetrahedron Lett. 1993, 34, 6395-6398. 
https://doi.org/10.1016/0040-4039(93)85054-Z

19. Khalifa, M. M.; Bodner, M. J.; Berglund, J. A.; Haley, M. M.; Tetrahedron Lett. 2015. 56, 4109-4111. https://doi.org/10.1016/j.tetlet.2015.05.029

20. Yin, Z.; Zhang, Z.; Zhu, J.; Wong, H.; Kadow, J. F.; Meanwell, N. A.; Wang, T.; Tetrahedron Lett. 2005, 46, 4919-4923.

https://doi.org/10.1016/j.tetlet.2005.04.142

21. Dabak, K. Turk. J. Chem. 2002, 26, 547-550.

http://journals.tubitak.gov.tr/chem/issue.htm?id=424

22. Khilifi, A.; Raouafi, N.; Tapsoba, I.; Boujlel, K.; Benkhoud, M. L. J. Sulfur Chem. 2008, 29, 593-605. httpts://doi.org/10.1080/17415990802346002

23. Sondhi, S. M.; Rani, R.; Roy, Partha.; Agrawal, S. K.; Saxena, A. K. Eur. J. Med. Chem. 2010, 45, $902-908$. https://doi.org/10.1016/i.ejmech.2009.11.030

24. Arya, S.; Kumar, N.; Roy, P.; Sondhi, S. M. Eur. J. Med. Chem. 2013, 59, 7-14. https://doi.org/10.1016/j.ejmech.2012.10.046

25. Sielechi, T. M.; Liu, J.; Mousa, S. A.; Racanelli, A. L.; Hausner, E. A.; Wexler, R. R.; Olson, R. E. Bioorg. Med. Chem. Lett. 2001, 11, 2201-2204.

https://doi.org/10.1016/S0960-894X(01)00406-1

26. Buckman, B. M.; Chou, Y. L.; McCarrick, M.; Liang, A.; Lentz, D.; Mohan, R.; Morrissey, M. M.; Shaw. K. J.; Trinh, L.; Light, D. R. Bioorg. Med. Chem. Lett. 2005, 15, 2249-2252.

https://doi.org/10.1016/j.bmcl.2005.03.019

27. Booth, B. L.; Alves, M. J.; Proença, M. F. J. R. P. J. Chem. Soc. Perkin Trans. 1990, 1705 https://doi.org/10.1039/P19900001705

28. Alves, M. J.; Al-Duaij, O.Kh.; Booth, B. L.; Carvalho, A.; Eastwood, P.R.; Proença, M. F. J. R. P. J. Chem. Soc. Perkin Trans 1. 1990, 1705.

http://doi.org/10.1039/P19900001705

29. Woodward, D.W. U.S. Patent 1950, 2, 534331.

30. Zadeh, A. Y.; Booth, B. L. Synth. Commun. 2001, 31, 3225-3230. https://doi.org/10.1081/SCC-100106031

31. Nakamura, H.; Sasaki, Y.; Uno, M.; Yoshikawa, T.; Asano, T.; Ban, H. S.; Fukazawa, H.; Shibuya, M.; Uehara, Y. Bioorg. Med. Chem. Lett. 2006, 16, 5127-5131.

https://doi.org/10.1016/j.bmcl.2006.07.075

32. Wendt, M. D.; Geyer, A.; McClellan, W. J.; Rockway, T. W.; Weitzberg, M.; Zhao, X.; Mantei, R.; Stewart, K.; Nienaber, V.; Klinghofer, V.; Giranda, V. L. Bioorg. Med. Chem. Lett. 2004, 14, 3063-3068.

33. https://doi.org/10.1016/i.bmcl.2004.04.030

34. Sondhi, S. M.; Singh, J.; Kumar, A.; Jamal, H.; Gupta, P. P. Eur. J. Med. Chem. 2009, 44, 1010-1015. https://doi.org/10.1016/i.ejmech.2008.06.029

35. Ludovici, D. W.; Kukla, M. J.; Grous, P. G.; Krishnan, S.; Andries, K.; De Bethune, M.-P.; Azijn, H.; Pauwels, R.; De Clercq, E.; Arnold, E. Janssen, P. A. J. Biorg. Med. Chem. Lett. 2001, 11, 2225-2228. https://doi.org/10.1016/S0960-894X(01)00410-3

36. Judkins, B. D.; Allen, D. G.; Cook, T. A.; Evans, B.; Sardharwala, T. E. Synth. Commun. 1996, 26, 43514367.

https://doi.org/10.1080/00397919608003838

37. Reichert, A.; Fröhlich, R.; Ferguson, R.; Kraft, A. J. Chem. Soc., Perkin Trans 1. 2001, 1321-1328. http://doi.org/10.1039/B009451J 
38. Poulain, R. F.; Tartar, A. L.; Deprez, D. P. Tetrahedron Lett. 2001, 42, 1495-1498.

https://doi.org/10.1016/S0040-4039(00)02293-0

39. Renodon-Corniere, A.; Dijols, S.; Perollier, C.; Lefevre-Groboillot, D.; Boucher, J.-L.; Attias, R.; Sari, M.-A.; Stuehr, D.; Mansuy, D. J. Med. Chem. 2002, 45, 944-954.

https://doi.org/10.1021/im011006h

40. Oberlander, E. A.; Tebby, J. C. Arkivoc 2000, iii, 320-342.

http://dx.doi.org/10.3998/ark.5550190.0001.316

41. Das, V. K.; Thakur, A. J. Tetrahedron Lett. 2013, 54, 4164-4166.

https://doi.org/10.1016/j.tetlet.2013.05.096

42. Charette, A. B.; Grenon, M. Tetrahedron Lett. 2000, 41, 1677-1680.

https://doi.org/10.1016/S0040-4039(00)00040-X

43. Obenauf, J.; Kretschmer, W.; Bauer, T.; Kempe, R. Eur. J. Inorg. Chem. 2013, 537-544.

https://doi.org/10.1002/ejic.201201194

44. Hagadorn, J. R.; McNevin, M. J. Organometallics 2003, 22, 609-611.

https://doi.org/10.1021/om020960p

45. Yang, H. J.; Sun, W. H.; Li, Z. L.; Ma, Z. Chinese Chem. Lett. 2002, 13, 3-7.

46. Chavan, N. L.; Naik, N. H.; Nayak, S. K.; Kusurkar, R. S. Arkivoc 2010, ii, 248-255.

http://dx.doi.org/10.3998/ark.5550190.0011.220

47. Mahajan, U. S.; Godinde, R. R.; Mandhare, P. N. Synthetic Commun. 2011, 41, 2195-2199.

https://doi.org/10.1080/00397911.2010.488307

48. Philip, S. K.; Rajasekharan, K. N. Synthetic Commun. 2011, 41, 1593-1602.

https://doi.org/10.1080/00397911.2010.488312

49. Cheng, K. M.; Huang, Y. Y.; Huang, J. J.; Kaneko, K.; Kimura, M.; Takayama, H.; Juang, S. H.; Wong, F. F.

Bioorg. Med. Chem. Lett. 2010, 20, 6781-6784.

https://doi.org/10.1016/j.bmcl.2010.08.133

50. Salva, M. C.; Garvin, C.; Antilla, J. C. J. Org. Chem. 2011, 76, 1456-1459.

https://doi.org/10.1021/jo102235u

51. McGowan, M. A.; McAvoy, C. Z.; Buchwald, S. L. Org. Lett. 2012, 14, 3800-3803.

https://doi.org/10.1021/ol301700y

52. Mazumdar, S. N.; Mahajan, M. P. Synthesis. 1990, 5, 417-422.

https://doi.org/10.1055/s-1990-26892

53. Dey, P. D.; Sharma, A. K.; Rai, S. N.; Mahajan, M. P. Tetrahedron. 1995, 51, 7459-7464.

https://doi.org/10.1016/0040-4020(95)00372-F

54. Brindley, J. C.; Caldwell, J. M.; Meakins, G. D.; Plackett, S. J.; Price, S. J. J. Chem. Soc., Perkin Trans. 1.

1987, 1153-1157.

http://doi.org. 10.1039/P19870001153

55. Bedi, P. M.; Mahajan, M. P.; Kapoor, V. K. Bioorg. Med. Chem. Lett. 2004, 14, 3821-3824.

https://doi.org/10.1016/j.bmcl.2004.04.104

56. Mishra, A.; Mohabey, M. H. Asian J. Chem. 2002, 14, 1097-1098.

http://doi.org/10.1107/S1600536811025864

57. Katritzky, A. R.; Cai, C.; Singh, S. K. J. Org. Chem., 2006, 71, 3375-3380.

https://doi.org/10.1021/jo052443x

58. Harjani, J. R.; Liang, C.; Jessop, P. G. J. Org. Chem., 2011, 76, 1683-1691.

https://doi.org/10.1021/jo102358d 
59. Rozentsveig, I. B.; Levkovskaya, G. G.; Rozentsveig, G. N.; Mirskova, A. N.; Krivdin, L. B.; Larina, L. I.;

Albanov, A. I. Tetrahedron Lett. 2005, 46, 8889-8893.

https://doi.org/10.1016/j.tetlet.2005.10.079

60. Chen, S.; Xu, Y.; Wan, X. Org. Lett. 2011, 13, 6152-6155.

https://doi.org/10.1021/ol2024604

61. Kong, Y. Yu, L. Cao, J. Synthesis 2014, 183-188.

62. Lee, M. Y.; Kim, M. H.; Kim, J.; Kim, B. T.; Jeong, I. H.; Chang, S.; Kim, S. H.; Chang, S. Y. Bioorg. Med.

Chem. Lett. 2010, 20, 541-545.

https://doi.org/10.1016/j.bmcl.2009.11.104

63. Suarez, J. R.; Kwiczak, J.; Grenda, K.; Jimeno, M. L.; Chiara, J. L. Adv. Synth. Catal. 2013, 355, 913 - 918. https://doi.org/10.1002/adsc.201201001

64. Suarez, J. R.; Trastoy, B.; Perez-Ojeda, M. E.; Marin-Barrios, R; Chiara, J. L. Adv. Synth. Catal. 2010, 352, 2515-2520.

https://doi.org/10.1002/adsc.201000417

65. Owens, T. D.; Souers, A. J.; Ellman, J. A. J. Org. Chem. 2003, 68, 3-10. https://doi.org/10.1021/jo020524c

66. Owens, T. D. Hollander, F. J. Oliver, A. G. Ellman, J. A. J. Am. Chem. Soc. 2001, 123, 1539- 1540. https://doi.org/10.1021/ja005635c

67. Bosch, I.; Gonzalez, A.; Urpi, F.; Vilarrasa, J. J. Org. Chem. 1996, 61, 5638-5643.

https://doi.org/10.1021/j0951951b

68. Katritzky, A. R.; Zhang, G.; Jiang, J. J. Org. Chem. 1994, 59, 4556-4560.

https://doi.org/10.1021/jo00095a035

69. Palacios, F.; Retana, M. O.; Pagalday, J. Eur. J. Org. Chem. 2003, 913-919.

https://doi.org/10.1002/ejoc.200390139

70. Liu, K.-C.; Shelton, B. R.; Howe, R. K. J. Org. Chem. 1980, 45, 3916-3918.

https://doi.org/10.1021/jo01307a039

71. Schwarz, L.; Girreser, U.; Ciement, B. Eur. J. Org. Chem. 2014, 1961-1975.

https://doi.org/10.1002/ejoc.201301622

72. Armand, J.; Minvielle, R. M. Compt. Rend. 1965, 260, 2512-2515.

73. Tatala, K. K. R.; Whitby, R. J.; Light, M. E.; Hurtshouse, M. B. Tetrahedron Lett. 2004, 45, 6991-6994. https://doi.org/10.1016/i.tetlet.2004.07.150

74. Das, V. K.; Thakur, A. J. Tetrahedron Lett. 2013, 54, 4164-4166. https://doi.org/10.1016/i.tetlet.2013.05.096

75. Adiyala, P. R.; Chandrasekhar, D.; Kapure, J. S.; Reddy, C. N.; Maurya, R. A. Beilstein J. Org. Chem. 2014, 10, 2065-2070.

https://doi.org/10.3762/bjoc.10.214

76. Singh, S.; Nicholas, K. M. Synth. Commun. 1997, 27, 4021-4025.

https://doi.org/10.1080/00397919708005925

77. Wong, C.-H.; Nguyen, L.; Peh, J.; Luu, L. M.; Sanchez, J. S.; Richardson, S. L.; Tuccinardi, T.; Tsoi, H.; Chan, W. Y.; Chan, H. Y. E.; Baranger, A. M.; Hergenrother, P. J.; Zimmerman, S. C. J. Am. Chem. Soc. 2014, 136, 6355-6361.

https://doi.org/10.1021/ja5012146

78. Moormann, A. E.; Wang, J. L.; Palmquist, K. E.; Promo, M. A.; Snyder, J. S.; Scholten, J. A.; Massa, M. A.; Sikorski, J. A.; Webber, R. K. Tetrahedron. 2004, 60, 10907-19014. 
https://doi.org/10.1016/i.tet.2004.09.030

79. Degardin, M.; Wein, S.; Durand, T.; Escale, R.; Vial, H.; Hoang, Y. V. Bioorg. Med. Chem. Lett. 2009, 19, 5233-5236.

https://doi.org/10.1016/j.bmcl.2009.07.001

80. Stephens, C. E.; Tanious, F.; Kim, S.; Wilson, W. D;. Schell, W. A.; Perfect, J. R.; Franzblau, S. G.; Boykin, D. W. J. Med. Chem. 2001, 44, 1741-1748.

https://doi.org/10.1021/jm000413a

81. Stephens, C. E.; Brun, R.; Salem, M. M.; Werbovetz, K. A.; Tanious, F.; Wilson, W. D.; Boykin, D. W.

Bioorg. Med. Chem. Lett. 2003, 13, 2065-2069.

https://doi.org/10.1016/S0960-894X(03)00319-6

82. Makarycheva-Mikhailova, A. V.; Bokach, N. A.; Kukushkin, V. Y.; Kelly, P. F.; Gilby, L. M.; Kuznetsov, M. L.; Holmes, K. E.; Haukka, M.; Parr, J.; Stonehouse, J. M.; Elsegood, M. R. J.; Pombeiro, A. J. L. Inorg. Chem. 2003, 42, 301-311.

https://doi.org/10.1021/ic025960w

83. Kelly, P. F.; Slawin, A. M. Z. Eur. J. Inorg. Chem. 2001, 1, 263-265. https://doi.org/10.1002/1099-0682(20011)2001:1<263::AID-EJIC263>3.0.CO;2-E

84. Grundy, J.; Coles, M. P.; Hitchcock, P. B. J. Organomet. Chem. 2002, 662, 178-187. https://doi.org/10.1016/S0022-328X(02)01922-8

85. Garcia, M. B.; Torres, R. A.; Orelli, L. R. Tetrahedron Lett. 2006, 47, 4857-4859. https://doi.org/10.1016/i.tetlet.2006.05.042

86. Kumagai, N.; Matsunaga, S.; Shibasaki, M. Angew. Chem. 2004, 116, $484-488$. https://doi.org/10.1002/ange.200352750

87. Klimova, E. I.; Dominguez, V. S.; Garcia, J. S.; Klimova, T.; Backinowsky, L. V.; Alamo, M. F.; Garcia, M. M. Mendeleev Commun. 2011. 21, 307-308. https://doi.org/10.1016/j.mencom.2011.11.004

88. Graham, W. H. J. Am. Chem. Soc. 1965, 87, 4396-4397. https://doi.org/10.1021/ja00947a040

89. Bose, A. K.; Kugajevsky, I. Tetrahedron 1967, 23, 957-963. https://doi.org/10.1016/0040-4020(67)85044-0

90. Ito, K.; Kizuka, Y.; Ihara, S. J. Heterocyclic Chem. 2006, 43, 1217-1224.

https://doi.org/10.1002/ihet.5570430512

91. Ito, K.; Kizuka, Y.; Hirano, Y. J. Heterocyclic Chem. 2005, 42, 583-588. https://doi.org/10.1002/ihet.5570420417

92. Ihara, S.; Soma, T.; Yano, D.; Aikawa, S.; Yoshida, Y. Synth. Commun. 2001. 41, 3600-3608. https://doi.org/10.1080/00397911.2010.517365

93. Gomaa, M. A. M.; Döpp, D. Tetrahedron 2003, 59, 5887-5891. https://doi.org/10.1016/S0040-4020(03)00941-4

94. Jalani, H. B.; Pandya, A. N.; Baraiya, A. B.; Kaila, J. C.; Pandya, D. H.; Sharma, J. A.; Sudarsanam, N.; Vasu, K. K. Tetrahedron Lett. 2011, 52, 6331-6335. https://doi.org/10.1016/i.tetlet.2011.08.149

95. Franklin, P. X.; Pillai, A. D.; Rathod, P. D.; Yerande, S.; Nivsarkar, M.; Padh, H.; Vasu, K. K.;Sudarsanam, V. Eur. J. Med. Chem. 2008, 43, 129.

https://doi.org/10.1016/i.ejmech.2007.02.008 
96. Jalani, H. B.; Pandya, A. N.; Pandya, D. H.; Sharma, J. A.; Sudarsanam, V.; Vasu, K. K. Tetrahedron Lett. 2013, 54, 5403-5406.

https://doi.org/10.1016/j.tetlet.2013.07.122

97. Khilifi, A.; Raouafi, N.; Tapsoba, I.; Boujlel, K. J. Sulfur Chem. 2008, 593-605. https://doi.org/10.1080/17415990802346002

98. Gupta, S.; Agarwal, P. K.; Kundu, B. Tetrahedron Lett. 2010, 51, 1887-1890. https://doi.org/10.1016/j.tetlet.2010.02.019

99. Zadeh, A. Y.; Sharifi, Z. Phosphorus, Sulfur, Silicon 2006, 181, 1339-1343. https://doi.org/10.1080/10426500500326982

100. Liu, X.; Wang, D.; Chen, Y.; Tang, D.; Chen, B. Adv. Synth. Catal. 2013, 355, 2798 - 2802. https://doi.org/10.1002/adsc.201300590

101. Li, Y.; Cheng, L.; Shao, Y.; Jiang, S.; Cai, J.; Qing, N. Eur. J. Org. Chem. 2015, 4325-4329. https://doi.org/10.1002/ejoc.201500305

102. Brasche, G.; Buchwald, S. L. Angew. Chem. Int. Ed. 2008, 47, 1932 -1934. https://doi.org/10.1002/anie.200705420

103. Givens, M. D.; Dykstra, C. C.; Brock, K. V.; Stringfellow, D. A.; Kumar, A.; Stephens, C. E. Goker, H.; Boykin, D. W. Antimicrob. Agents Chemother. 2003, 47, 2223-2230. https://doi.org/10.1128/AAC.47.7.2223-2230.2003

104. Stolic, I.; Paljetak, H. C.; Peric, M.; Matijasic, M.; Stepanic, V.; Verbanac, D.; Bajic, M. Eur. J. Med. Chem. 2015. 90, 68-81. https://doi.org/10.1016/j.ejmech.2014.11.003

105. Li, S.; Li, Z.; Yuan, Y.; Li, Y.; Zhang, L.; Wu, Y. Eur. J. Chem. 2013, 19, 1496-1501. https://doi.org/10.1002/chem.201202402

106. Sondhi, S. M.; Dinodia, M.; Kumar, A. Bioorg. Med. Chem. 2006, 14, 4657-4663. https://doi.org/10.1016/j.bmc.2006.02.014

107. Sondhi, S. M.; Dinodia, M.; Jain, S.; Kumar, A. Eur. J. Med. Chem. 2008, 43, 2824-2830. https://doi.org/10.1016/i.ejmech.2007.10.005

108. Liubchak, K.; Nazarenko, K.; Tolmachev, A. Tetrahedron. 2012, 68, 2993-3000. https://doi.org/10.1016/i.tet.2012.02.027

109. Kumar, T.; Verma, D.; Menna-Barreto, R. F. S.; Valenca, W. O.; da Silva Júnior, E. N.; Namboothiri, I. N. Org. Biomol. Chem., 2015, 13, 1996-2004. https://doi.org/10.1039/C4OB02561J

110. Gopi, E.; Kumar, T.; Menna-Barreto, R. F. S.; Valença, W. O.; da Silva Júnior, E. N.; Namboothiri, I. N. N. Org. Biomol. Chem., 2015, 13, 9862-9871. https://doi.org/10.1039/C5OB01444A

111. Okuda, K.; Ide, R.; Uramaru, N.; Hirota, T. J. Heterocyclic Chem. 2015, 52, 880-887. https://doi.org/10.1002/jhet.2033

112. Wu, Y.; Zhang, Y. Tetrahedron Lett. 2008, 49, 2869-2871. https://doi.org/10.1016/j.tetlet.2008.03.030

113. Sun, Y.; Wu, W.; Jiang, H. Eur. J. Org. Chem. 2014, 4239-4243. https://doi.org/10.1002/ejoc.201402194

114. Kim, H. Y.; Kwak, S. H.; Lee, G. H.; Gong, Y. D. Tetrahedron 2014, 70, 8737-8743. https://doi.org/10.1016/i.tet.2014.09.023

115. Boehringer, M.; Loeffler, B. M.; Peters, J.-U.; Steger, M.; Weiss, P. Patent 2003, 068757 A1. 
116. Sudheendran, K.; Schmidt, D.; Frey, W.; Conrad, J. Tetrahedron Lett. 2014, 70, 1635-1645. https://doi.org/10.1016/j.tet.2014.01.019

117. Yao, T. Tetrahedron Lett. 2015, 56, 4623-4626. https://doi.org/10.1016/j.tetlet.2015.06.017

118. Gug, F.; Bach, S.; Blondel, M.; Vierfond, J. M.; Martin, A. S.; Galons, H. Tetrahedron 2004, 60, 4705-4708. https://doi.org/10.1016/i.tet.2004.03.062

119. Gomaa, M. A.-M.; Döpp, D. Synthesis 2003, 1545-1548.

http://doi.org/10.1055/s-2003-40522

120. Hu, M.; Wu, J.; Zhang, Y.; Qiu, F.; Yu, Y. Tetrahedron Lett. 2011, 67, 2676-2680. https://doi.org/10.1016/i.tet.2011.01.062

121. Sheibani, H.; Seifi, M.; Bazgir, A. Synthetic Commun. 2009, 39, 1055-1064. https://doi.org/10.1080/00397910802474982

122. Aly, A. A.; Nour-El-Din A. M.; Gomaa, M. A.-M.; Brown, A. B.; Fahmi, M. S. J. Chem. Res. 2007, 439-441. https://doi.org/10.3184/030823407X234563

123. Cheng, G.; Li, S.; Li, J.; Hu, Y. Bioorg. Med. Chem. Lett. 2008, 18, 1177-1180. https://doi.org/10.1016/j.bmcl.2007.11.117

124. Mirallai, S. I.; Manos, M. J.; Koutentis, P. A. J. Org. Chem. 2013, 78, 9906-9913. https://doi.org/10.1021/j0401648t

125. Szczepankiewicz, W.; Kuznik, N. Tetrahedron Lett. 2015, 56, 1198-1199. https://doi.org/10.1016/j.tetlet.2015.01.133

126. Szczepankiewicz, W.; Kuznik, N.; Boncel, S.; Siewniak, A. Chem. Heterocycl. Compds. 2014, 50, $1291-1297$. https://doi.org/10.1007/s10593-014-1591-3

127. Guo, W. Chinese Chem. Lett. 2015, 27. 47-50. https://doi.org/10.1016/j.cclet.2015.09.012

128. Baelen, G. V.; Kuijer, S.; Rycek, L.; Sergeyev, S.; Janssen, E.; Kanter, F. J. J.; Maes, B. U. W.; Ruijter, E.; Orru, R. V. A. Eur. J. Chem. 2011, 17, 15039-15044. https://doi.org/10.1002/chem.201102468

129. Elkanzi, N. A. A.; Aly, A. A.; Shawky, A. M.; El-Sheref, E. A.; Morsy, N. M.; El-Reedy, A. A. M. J. Heterocyclic Chem. 2016, 53, 1941-1944.

https://doi.org/10.1002/jhet.2510

130. Hajri, A.; Abderrahim, R. Phosphorus, Sulfur, Silicon, Relat. Elem. 2011. 186, 520-525. https://doi.org/10.1080/10426507.2010.506453

131. Aly, A. A.; El-Shaieb, K. M. J. Chem. Res. 2007, 207-209. https://doi.org/10.3184/030823407X207086

132. Liu, C.; Lin, J.; Leftheris, K. Tetrahedron Lett. 2007, 48, 435-437. https://doi.org/10.1016/i.tetlet.2006.11.069

133. Li, N.; Tu, M. S.; Jiang, B.; Wang, X.; Tu, S. J. Tetrahedron Lett. 2013, 54, 1743-1746. https://doi.org/10.1016/i.tetlet.2013.01.086

134. Elmore, D. T.; Ogle, J. R.; Fletcher, W.; Toseland, P. A. J. Chem. Soc. 1956, 4458-4462. https://doi.org/10.1039/ir9560004458

135. Durant, G. D. J. Chem. Soc. 1967, 92-97.

136. Elkafrawy, A. F.; Moussa, G. E. M.; Elaasar, N. K. Phosphorus, Sulfur, Silicon 1991, 62, 275-279. https://doi.org/10.1080/10426509108034487

137. Ferwanah, A. E. S.; Awadallah, A. M.; El-Sawi, E. A.; Dalloul, H. M. Synth.s Commun. 2003, 33, $1245-1250$. 
https://doi.org/10.1081/SCC-120018683

138. McConnachie, G.; Neugebauer, F. A. Tetrahedron 1975, 31, 555-560.

https://doi.org/10.1016/0040-4020(75)85029-0

139. Dalloul, H. M. M. Tetrahedron Lett. 2009. 65, 8722-8726.

https://doi.org/10.1016/i.tet.2009.08.036

140. Aly, A. A.; El-Shaieb, K. M. J. Chem. Res. 2007, 563-566.

https://doi.org/10.3184/030823407X255579

\section{Authors' Biographies}

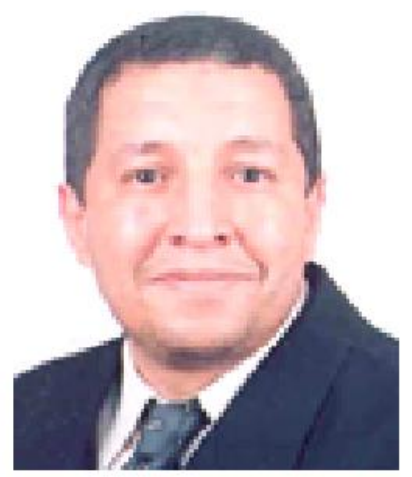

Prof. Ashraf Abd El-Moneim Aly Shehata, Chemistry Department, Faculty of Science, Minia University, ElMinia, Egypt, Organic Division, Minia University, 61519-El-Minia, Egypt. Born 14/5/63. Editorial Boards of: Organic Chemistry International (OCl), and Arkivoc. Referee in SciEP Journal Review Form: World Journal of Organic Chemistry" Awarded from the Academy of Science and Technology, Cairo, Egypt, "The State's Encouragement National Prize in Organic Chemistry" (2004). Awarded DAAD scholarship for two months from 12 August 2005 till 12 October 2005 with Prof Dr Henning Hopf. Awarded three months of DFG Fellowship by Prof Stefan Bräse, KIT, Institute of Organic Chemistry (from August 2015 to 1 st October 2015). Awarded one month of fellowship by CRC 3MET in Karlsruhe (KIT); member of the referees' board of the following Societies and/or Journals: 1) J. Sulf. Chem., 2) American Chemical Society (J. Org. Chem. \& Org. Letters), Royal Society of Chemistry (Org. \& Biomol. Chem.), Molecules and Arkivoc. Published 125 papers. His main research is focused on the synthesis of biologically active heterocycles.

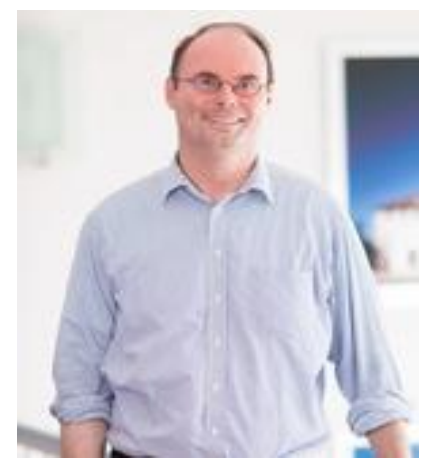

Prof. Stefan Bräse studied in Göttingen, Bangor (UK) and Marseille and received his Ph.D. in 1995, after working with Armin de Meijere in Göttingen. After post-doctoral appointments at Uppsala University (Jan E. Bäckvall) and The Scripps Research Institute (K. C. Nicolaou), he began his independent research career at the 
RWTH Aachen in 1997 (associated to Dieter Enders). In 2001, he finished his Habilitation and moved to the University of Bonn as Professor of Organic Chemistry. Since 2003 he is full Professor at the Karlsruhe Institute of Technology and since 2012 Director of the Institute of Toxicology and Genetics at the KIT. His research interests include methods in drug-discovery (including drug-delivery), combinatorial chemistry towards the synthesis of biologically active compounds, total synthesis of natural products and nanotechnology.

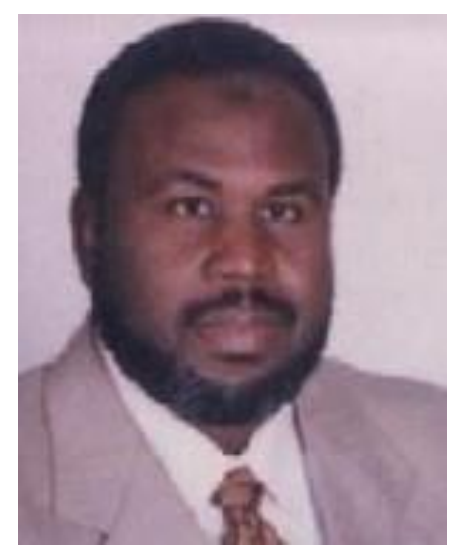

Prof Mohsen Abdel-Motaal Gomaa was born in El-Minia (Egypt). He is a Professor of Organic Chemistry in Chemistry Department, Faculty of Science, Minia University, El-Minia, Egypt. He completed his PhD under the guidance of Professor Dietrich Döpp at Duisburg Universität (Germany) in the field of organic synthesis of hetrocyclic copmounds. In 1994 he obtained his PhD from Minia University. Since 1994 he is a junior research group leader at the Chemistry Department, Minia University. He is a full professor since 2005 at the same university. He received DFG fellowship in 1996 at Duisburg Universität, Duisburg, Germany, and Georg Mercator Duisburg Universität fellowship in 2001, and DAAD fellowship in 2001 at TU Dresden, Dresden, Germany. In 2004 he was awarded The State's Encouragement National Prize in Organic Chemistry from the Academy of Science and Technology, Cairo, Egypt. Recently he was awarded a DFG fellowship at TU Kaiserslautern, Kaiserslautern, Germany. His research interests are synthesis of heterocyclic compounds of potential biological and/or pharmaceutical activities. His research interests cover chemical study of the reactivity of electron-rich compounds towards electron-poor compounds. 